San Jose State University

SJSU ScholarWorks

Master's Theses

Master's Theses and Graduate Research

1992

\title{
Effects of natural sunlight and moisture on the efficacy of Steinernema carpocapsae nematodes in controlling Trichoplusia ni and Agrotis ipsilon
}

Ali Fotovatjah

San Jose State University

Follow this and additional works at: https://scholarworks.sjsu.edu/etd_theses

\section{Recommended Citation}

Fotovatjah, Ali, "Effects of natural sunlight and moisture on the efficacy of Steinernema carpocapsae nematodes in controlling Trichoplusia ni and Agrotis ipsilon" (1992). Master's Theses. 456.

DOI: https://doi.org/10.31979/etd.nmb6-e6ct

https://scholarworks.sjsu.edu/etd_theses/456

This Thesis is brought to you for free and open access by the Master's Theses and Graduate Research at SJSU ScholarWorks. It has been accepted for inclusion in Master's Theses by an authorized administrator of SJSU ScholarWorks. For more information, please contact scholarworks@sjsu.edu. 


\section{INFORMATION TO USERS}

This manuscript has been reproduced from the microfilm master. UMI films the text directly from the original or copy submitted. Thus, some thesis and dissertation copies are in typewriter face, while others may be from any type of computer printer.

The quality of this reproduction is dependent upon the quality of the copy submitted. Broken or indistinct print, colored or poor quality illustrations and photographs, print bleedthrough, substandard margins, and improper alignment can adversely affect reproduction.

In the unlikely event that the author did not send UMI a complete manuscript and there are missing pages, these will be noted. Also, if unauthorized copyright material had to be removed, a note will indicate the deletion.

Oversize materials (e.g., maps, drawings, charts) are reproduced by sectioning the original, beginning at the upper left-hand corner and continuing from left to right in equal sections with small overlaps. Each original is also photographed in one exposure and is included in reduced form at the back of the book.

Photographs included in the original manuscript have been reproduced xerographically in this copy. Higher quality $6 " \times$ x 9 " black and white photographic prints are available for any photographs or illustrations appearing in this copy for an additional charge. Contact UMI directly to order.

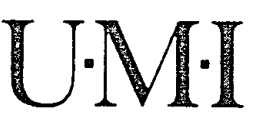

Univer sity Microfılms Internatıonal

A Bell \& Howell Intormation Company 300 North Zeeb Road. Ann Arbor. MI 48106-1346 USA

$313: 761-4700 \quad 800: 521-0600$ 

Order Number 1351027

Effects of natural sunlight and moisture on the efficacy of Steinernema carpocapsae nematodes in controlling Trichoplusia ni and Agrotis ipsilon

\author{
Fotovatjah, Ali, M.A.
}

San Jose State University, 1992

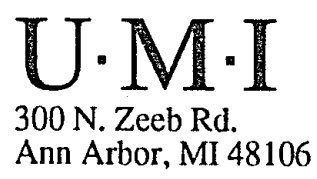



Effects of natural sunlight and moisture on the efficacy of

Steinernema carpocapsae nematodes in controlling Trichoplusia ni and Agrotis ipsilon

\author{
A Thesis \\ Presented to \\ The Faculty of the Department of Biological Sciences \\ San Jose State University \\ In Partial Fulfillment \\ of the Requirements for the Degree \\ Master of Arts
}

By

Ali Fotovatjah

December, 1992 
APPROVED FOR THE DEPARMENT OF BIOLOGICAL SCIENCES
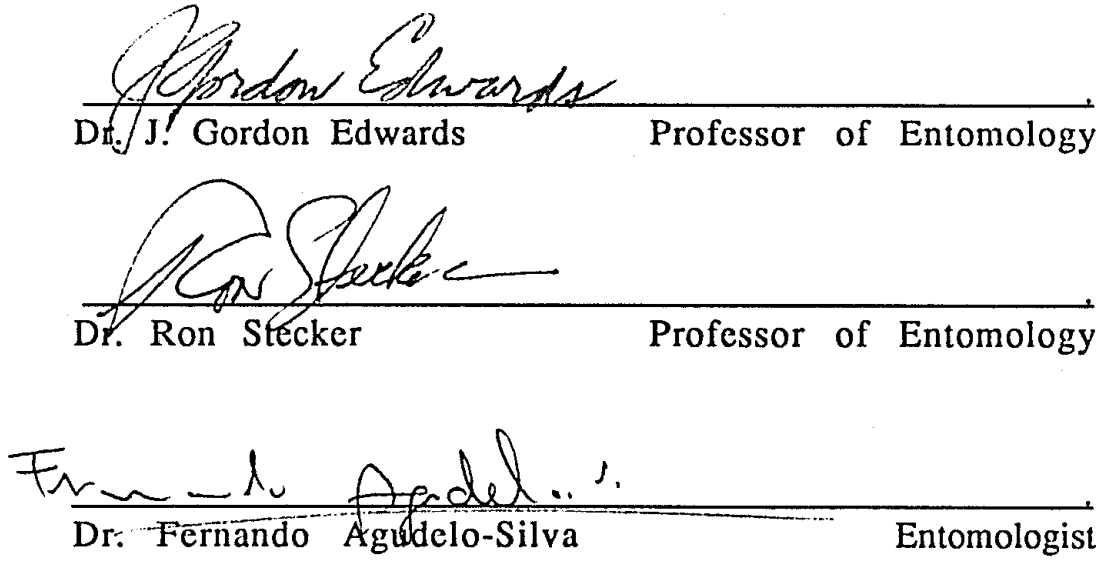

APPROVED FOR THE UNIVERSITY

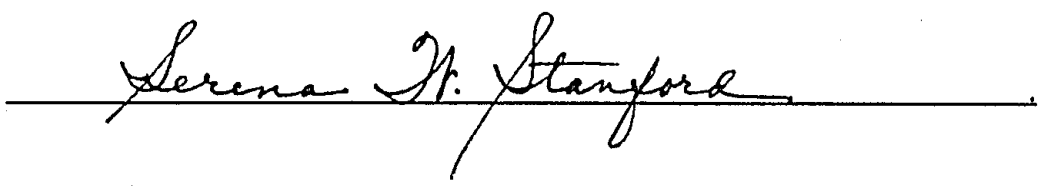




\begin{abstract}
Effects of natural sunlight and moisture on the efficacy of Steinernema carpocapsae nematodes in controlling Trichoplusia ni and Agrotis ipsilon
\end{abstract}

\title{
Ali Fotovatjah
}

The ability of Steinernema carpocapsae to survive environmental conditions and combat insect pests was tested on leaf and soil assays in the laboratory and in outdoor habitats.

The exposure of nematodes to direct sunlight and to less moist conditions decreased their efficacy. The longer nematodes had been exposed to sunlight, the less effective they were in entering and killing Trichoplusia larvac. Larval mortality caused by nematodes ranged from $100 \%$ to zero after the nematodes had been exposed to the sun for periods of 4 minutes to 192 minutes. Nematodes caused $83.3 \%$ to $85 \%$ mortality of Trichoplusia larvae when optimum moisture was present, whereas no mortality was obtained when moisture was essentially absent. Nematodes applied to moist soil killed 100\% of Agrotis larvac but only $40 \%$ to $48 \%$ control was achieved when nematodes were applied to dry soil. Application of nematodes in late afternoon sunshine resulted in better control of Agrotis larvac ( $88 \%$ to $92 \%$ ) than applications during sunnicr morning exposures (20\% to $28 \%)$. 


\section{Acknowledgments}

I would like to thank Dr. Fernando Augdelo-Silva who offered his professional guidance, ideas, and patience; without his help this study would not have been possible.

My sincere thanks to Dr. J. Gordon Edwards and Dr. Ron Stecker for their support throughout the course of this study and for their assistance in reviewing and preparing this manuscript. 


\section{Table of Contents}

Title page i

Signature page ii

Abstract iii

Acknowledgments iv

Table of Contents $\quad$ v

A. Introduction 1

B. Literature Review on Nematodes 2

1. Classification of Entomogenous Nematodes 2

2. Relationships between Insects and Nematodes 3

3. Methods of Infecting Hosts 4

4. Steinernema carpocapsae All 6

5. The Bacterium, Xenorhabdus

6. Behavior of Infected Lepidopterous Larvae $\quad 7$

7. Efficacy of Biological Control Measures Utilizing Nematodes 8

a. Advantages of Nematode Control Measures $\quad 8$

b. Disadvantages of Nematode Control Measures 10

C. Methods and Materials 13

1. Lepidopterous Pests Exposed to Nematodes 13

$\begin{array}{ll}\text { a. Trichoplusia ni Hübner } & 13\end{array}$

$\begin{array}{ll}\text { Host Plants } & 14\end{array}$

Damage 15

$\begin{array}{ll}\text { Control Measures } & 15\end{array}$ 
b. Agrotis ipsilon Hufangel 16

$\begin{array}{ll}\text { Host Plants } & 18\end{array}$

Damage 18

Control Measures 18

2. Rearing Nematodes 19

3. Rearing Agrotis and Trichoplusia 20

4. The Experimental Plant 21

5. Tests 22

$\begin{array}{ll}\text { a. With Trichoplusia ni } & 22\end{array}$

b. With Agrotis ipsilon 25

D. Results and Conclusions 28

1. With Trichoplusia ni 28

2. With Agrotis ipsilon 37

E. Discussion 43

F. Tables 46

G. Graphs 68

H. Bibliography 79 


\section{A. Introduction}

The problems associated with insect pest control are constantly changing. We can no longer rely only on chemical insecticides to protect crops. Some insecticides cannot be used after edible portions of a crop have been formed, and with successive insect instars it becomes increasingly difficult to control some insect pests. Many kinds of insects have developed resistance to insecticides, and sometimes alternative insect pests have replaced those which were controlled. Environmental contamination has become a matter of great concern, and the adverse effects of chemical insecticides on the environment are good reasons to seek alternative control measures.

Parasitic nematodes have a good potential as biological control agents against some insect pests (Gaugler, 1981) and may be effective alternatives for the future. The objective of this research was to evaluate the effectiveness of certain parasitic nematodes in combatting lepidopterous larvae.

For this study, cabbage (Brassica oleracea), which is one of the most important commercially grown vegetable crops in the USA (McCollum, 1980), was selected. Black cutworms (Agrotis ipsilon Hufangel) and cabbage loopers (Trichoplusia ni Hübner), which are the most serious pests of cabbage (Metcalf, 1982), were exposed to nematode (Steinernema carpocapsae $A l l$ ) in the laboratory and in small greenhouse plot trials at San Jose State University. 


\section{B. Literature Review on Nematodes}

Nematodes, or "round worms," range from microscopic to macroscopic in size and are among the most abundant groups of living animals. They belong in the phylum Nematoda, and are found in a great diversity of environments (Poinar, 1983).

\section{Classification of Entomogenous Nematodes}

Nematodes are categorized into two groups, depending on their feeding habits. The first group includes free-living nematodes which feed on microorganisms and live in soil or in fresh or saline water. The second group contains parasitic nematodes that may infest insects, other animals, or plants.

For this study I concentrated on some of the nematodes that are associated with insects and are therefore known as "entomogenous nematodes." There are 27 families of entomogenous nematodes in nine major groups: rhabditoid, tylenchoid, apheenchoid, strongyloid, oxyuroid, ascaridoid, spiruroid, filarioid, and merminoid. The first eight groups belong to the Class Secernentea and the last one belongs to the Class Adenophorea. Nine families include species that are considered to have potential for the biological control of insect pests. These nine families are Mermithidae, Neotylenchydae, Allantonematidae, Diplogasteridae, Heterorhabditidae, Rhabditidae, Sphaerularidae, Steinernematidae and Tetradonematidae (Nickle, 
1967). Most of the studies associated with entomogenous nematodes have dealt with the Steinerematidae and Mermithidae (Petersen, 1981).

\section{Relationships between Insects and Nematodes}

There are three types of relationships between nematodes and their insect hosts. One is a phoretic relationship where the insect serves only as a means of transportation. The nematodes may occur internally in the genital chamber of both sexes or in the tracheae, head glands, or malpighian tubules of the insect. Others may occur externally, under the elytra of beetles, attached to the legs of flies, or on any part of the insect's exoskeleton. The insects may play an important role in the dissemination of nematodes, rather than just the survival of the worms (Bovien, 1937). Some members of the following families of nematodes have phoretic associations with insects: Rhabditidae, Diplogasteridae, Chambersiellidae, Cephalobidae, Aphelenchidae, Aphelenchoididae, Cylindrocorporidae, Dorylaimidae, Neotylenchidae, Mononchidae, Plectidae, Strongylidae, Tylenchidae and Panagrolaimidae.

The second type of relationship is facultative parasitism, in which the nematodes are able to parasitize insects yet still retain the ability to reproduce and develop under free-living conditions. They

obtain some of their nourishment from insects, but do not usually kill the hosts. During their non-insect cycle they obtain nourishment 
from fungi, bacteria and plants. These nematodes occur in the insect body cavity, intestine, malpighian tubules, pharyngeal glands, tracheae and collateral glands. Members of the family Rhabditidae, Panagrolaimidae, Diplogasteridae, Aphelenchoididae, Neotylenchidae and Steinernematidae display facultative parasitism (Poinar, 1972).

The third type of parasitism is obligate parasitism, where the nematodes require a living insect to complete their life cycle, and are capable of killing or sterilizing the host. These parasites usually occur in the body cavity of the host (families: Tetradonematidae, Allontonematidae, Sphaercularridae, Mermithidae, Entaphelenchidae, and Caraboneematidae) but some occur in the insect intestine (Diplogasteridae, Oxyridae) or reproductive system (Rhabditidae) (Cobb, 1919).

\section{Methods of Infecting Hosts}

Nematodes encounter insects in the environment, and enter through natural body openings in response to chemical stimuli (carbon dioxide or fecal components) and temperature gradients emitted by the host (Schmidt, 1978).

The third-instar nematodes, known as "dauer-larvae," infect the host through the mouth, anus or spiracle. The course of nematode infection depends on the nature of the host and on environmental conditions. The usual path of infection is through the insect's mouth. When the third instar is ingested by a host, it penetrates the gut wall 
and enters the hemocoel (Welch, 1963).

Infection can also occur through the spiracles. The third instar nematodes enter the spiracles and penetrate through the tracheae and into the hemocoel. Once inside the host's hemocoel, they transform into a normal feeding stage and molt to the fourth instar within a few hours (Poinar, 1976). At this time numerous bacteria, which were carried inside the invading nematodes, are released from the lumen of the anterior portion of the nematode's intestine and escape through the anus into the hemocoel. These bacteria are initially non-motile in a compact pellet (inside the third instar nematodes), but become motile after they enter the insect's blood. The bacteria quickly multiply in the hemolymph and spread through the blood cavity of the insect. The insect dies as the result of septicemia (Thomas, 1979).

The fourth instar nematodes soon develop to the adult stage, mate, and produce eggs in the insect hemolymph. After the eggs hatch, the young juveniles molt to the second instar, continue their development to the fourth instar, and become adults if sufficient host tissue is available. If not, they transform into the infective third instar "dauers," leave the host, and are likely to infest new hosts. The life cycle thus comprises six stages, which include eggs, four larval stages, and the adult (Nickle, 1977). As many as three generations may occur within one host; however, it depends on the condition and the size of the host. Each complete reproductive cycle requires nine to eleven days (Croll, 1977). 


\section{Steinernema carpocapsae All}

Steinernema belongs to the family Steinermatidae and is widely distributed in nature and in different geographical areas. They occur naturally in various areas of Europe and North America (Kaya, 1985). About 20 species of Steinernema have been described (Kaya, 1990), but only three species (glasaeri, feltiae and carpocapsae) have been used in insect control programs. Steinernema carpocapsae includes several different "strains" named according to their geographic origin, their specific features, or the persons credited with their isolation. Some of the most common strains are Czechoslovanian, DD136, Mexican, Agriotos, All, X-I, X-III, and X-IV (Poinar, 1979).

The adult female is almost transparent, rather plump, and measures from 0.8 to $2.5 \mathrm{~mm}$ or more. The head ends in three lips bearing papillae. The pharynx has an anterior cylindrical portion, followed by an isthmus and a terminal bulb with valvular apparatus. The rectum is located about 40 to 50 micrometers beyond the end of the gonads. The protruding vulva is very conspicuous (Wouts, 1980).

The adult male is slender and semi-transparent, measuring from 0.5 to $0.9 \mathrm{~mm}$. The tail has a variable number of genital papillae. Spicules are equal in size, with tips pointed, and with a ventral arch (Poinar, 1968). Males can be easily distinguished from females by their smaller size, greater activity and characteristically curved posterior end (Glaser, 1940).

According to Kaya (1990), the length of infective juveniles is 438 
to 650 microns. They are much narrower than parasitic juveniles, their mouth and anal openings are closed, the pharynx and intestine are collapsed, and their tail is pointed.

\section{The Bacterium, Xenorhabdus}

The bacterium that is associated with Steinernema was described by Thomas and Poinar in 1979 as Xenorhabdus luminescens. They are large (0.8-2.0 by $4.0-10.0$ micrometers), gram-negative, rod-shaped, anaerobic, facultative, entomopathogenic bacteria. They form colonies on nutrient agar that are smooth, moist, and somewhat granular in appearance. On Tergitol media the colonies become blue in color with maroon centers or blue-green with dark centers (Akhurst, 1980).

\section{Behavior of Infected Lepidopterous Larvae}

The nematodes inside the body of the host feed upon all types of the body tissues there. As the result, the caterpillars become sluggish, stop feeding, and usually die within 48 hours. The nematodes continue to develop and the host eventually becomes filled with a thin fluid swarming with larval nematodes. The cadavers are a light brown color at first, and become darker (Poinar, 1967). 


\section{Efficacy of Biological Control Measures Utilizing Nematodes}

Entomogenous nematodes have excellent potential as biological control agents against some insect pests. They possess most of the qualifications of good biocontrol agents. Nematodes as a group have a broad host range, however most are host specific. According to Poinar (1979) nearly 300 species from ten orders of insects have been reported to be infected by nematodes under laboratory conditions (most of the their hosts died within 48 hours). They can be mass produced on artificial media, and they can then be stored, alive, for several months (Bedding, 1984).

There are both advantages and disadvantages to reliance upon nematodes rather than other biological or chemical control measures. These will be discussed below.

\section{a. Advantages of Nematode Control Measures}

Behavior: One of the unique characteristics of entomogenous nematodes is that, unlike other biological agents, they do not depend upon insects to make contact. Rather, they go after the host.

Safety: Extensive testing has been conducted by the Environmental Protection Agency regarding the potential mammalian pathogenicity associated with entomogenous nematodes (Gaugler, 1979). The study showed that these nematodes (and their associated bacteria) cannot develop in vertebrates. The Environmental 
Protection Agency exempted nematodes from EPA registration requirements in December of 1981, because they were regarded as parasites rather than pathogens (Gorsuch, 1982).

Ecological aspects: As far as beneficial insects are concerned, Georgis (1987) found that nematodes cause no detrimental effect on populations of insect predators and parasites. Kaya (1982) reported that honey bees have a very low susceptibility to nematodes because the high temperature and lack of moisture in the brood inhibited nematode development.

Persistence: Efficacy of the nematodes usually depends on their persistence in the soil. They can persist in the soil for about 30 to 90 days, depending on temperature and moisture. Georgis (1987) showed that when the nematodes were applied in the soil to control Japanese beetle larvae, they not only controlled the spring generation of beetles, but also remained viable long enough to kill most of the beetle larvae of the late summer generation.

Compatibility: The infective (third instar) stage of nematodes (in the soil) is adapted for persistence in that environment. In the infective stage, nematodes have a tough outer cuticle, which enables them to resist a spray pressure of up to 300 pounds per square inch (Webster, 1980). The cuticle also protects them from many agricultural chemicals (insecticides, fungicides, herbicides, and fertilizers), and microbial insecticides. Because the nematodes are compatible with most common pesticides, they fit very well into integrated pest management programs. 
Resistance: No evidence of resistance build-up has yet been shown in insects infected with nematodes. That is because only a few bacteria are required to kill the host, and whenever a nematode enters a host, the bacteria which are released into the host's hemocoel kill that host. Thus, there are no survivors to initiate a resistant strain. It has been reported that a few insects may wall off or encapsulate the nematodes, but that is not effective when numerous nematodes are attacking simultaneously (Meyer, 1989).

\section{b. Disadvantages of Nematode Control Measures}

Susceptibility: Insects like white flies are too small in size for nematodes to enter. Also they do not live on or in the soil, where nematodes would be abundant, thus they have a very low susceptibility to nematode infection. Some insects, such as various insect pupae, have very few natural openings and have a hard cuticle that inhibits nematode entry. Other insects, like earwigs and thrips, are just too active for nematodes to enter. A few kinds of insects, like termites, apparently respond to nematodes defensively and are thus able to avoid infestations. Obviously, some insects are much less susceptible to nematodes than others.

Natural enemies: The most common natural enemies of entomogenous nematodes are various kinds of mites and some adult carabid beetles. They are not considered to be a major threat to nematodes (Nickel, 1984). 
Environmental restrictions: The abiotic factors, including moisture temperature radiation, and soil texture in the environment which directly affect the nematodes' survival, movement, and infectivity must be considered before any nematode applications (see the following discussion).

Moisture: Moisture has been regarded as one of the major factors for nematodes' survival and effectiveness (Simons, 1973). Because soil is the natural habitat for nematodes, they can survive in the soil without adequate moisture for a long time. According to Gray (1983), $90 \%$ of Steinernema carpocapsae survived at $79.5 \%$ RH after twelve days. Simons' study (1973) indicated that $80 \%$ of $S$. carpocapsae survived at $48.4 \% \mathrm{RH}$ (corresponds to a very dry soil) after four days. Soil moisture may not be a limiting factor for their survival, but it significantly influences nematodes' infectivity. Shetlar (1988) reported a $50 \%$ reduction in efficacy of $S$. carpocapsae against Japanese beetle, after the soil moisture was reduced form $40 \%$ to $25 \%$ RH. Moisture level is even more critical for nematodes where they are on exposed plant parts. Simons' study (1973) showed that $98 \%$ of the $S$. carpocapsae died after 36 hours if they were kept on leaves at a RH of $85 \%$. Moore (1973) reported that $S$. carpocapsae on the foliage in the field only live for a few hours.

Solar radiation: One of the other important factors limiting success of nematodes as biological control agents is sensitivity to solar radiation (Jaques, 1968). A reduction of infectivity and pathogenicity is the major adverse affect of solar radiation on 
exposed nematodes. According to Gaugler (1978), S. carpocapsae exposed to natural sunlight for 60 minutes lost $95 \%$ of their pathogenicity.

Temperature: Nematodes are also sensitive to temperature. Extreme temperature can be very detrimental to nematode survival and development. The optimum temperature for $S$. carpocapsae ranges between 20 and $28^{\circ} \mathrm{C}$, and they become less active when these values are exceeded (Byers, 1982). According to Kaya (1977), temperatures between 30 and $34^{\circ} \mathrm{C}$ reduce the nematode effectiveness because at that temperature nematodes can develop to the adult stage but cannot reproduce. On the other hand there is no effective development of these nematodes below $10^{\circ} \mathrm{C}$ or above $34^{\circ} \mathrm{C}$.

Soil texture: Soil texture affects nematode ability to survive, to move, and to infect hosts. The movement of nematodes is slowest in dense clay soil and is most rapid in sand and sandy loam soil (Moyel, 1980). It is difficult for nematodes to move in soil where gaps between particles are less than the width of the nematode's diameter. S. carpocapsae can migrate vertically or horizontally in soil up to $4.0 \mathrm{~cm}$ per day under favorable conditions (Schroeder, 1987). Survival of $S$. carpocapsae is the best in sandy soil and is the lowest in clay soil where aeration is limited because of smaller pore spaces (Molyneux, 1984). 


\section{Materials And Methods}

My research deals with the control of two lepidopteran pests on cabbage, and the interactions between those pests and the parasitic nematodes.

\section{Lepidopterous Pests Exposed to Nematodes}

Lepidoptera is an insect order containing thousands of species, many of which contain pests of considerable economic importance (Rosmoser, 1981). Trichoplusia ni (the cabbage looper) and Agrotis ipsilon (the black cutworm), which were utilized for this project, belong in the family Noctuidae, the largest family of lepidoptera, with 2700 species in north America (Borror, 1981).

\section{a. Trichoplusia ni Hübner}

Trichoplusia $n i$ is a cosmopolitan insect that was originally native to tropical or subtropical Africa. It is now found in North and South America from Canada to Argentina. It is also a common insect in Asia and Europe (Singh, 1985). These insects pass the winter as pupae attached to the underside of a leaf near its base and emerge as brown moths in the spring. Then they quickly fly, mate, and lay eggs. Trichoplusia lays 275 to 350 eggs singly on upper surfaces of leaves. The newly hatched eggs are spherical and white. A short time before 
hatching, they become flattened, with a convex top bearing radial lines, and are 0.6 to $0.7 \mathrm{~mm}$ in diameter (McKinney, 1944). The eggs hatch in three to ten days, depending on the temperature. The first instar larvae are dusky with a black head and a thoracic shield. Soon after they begin to feed, they become light-green in color. The fullgrown larvae are 35 to $40 \mathrm{~mm}$ long, with longitudinal white lines along the sides of the body. The larvae have only three pairs of abdominal prolegs, in addition to the anal pair. They tend to crawl in a looping manner. From this looping habit, the common name is derived (McKinney, 1944). The larvae pass through five instars, which takes about two to four weeks. After the feeding period has been completed, the full-grown larva spins a white cocoon, and then pupation takes place. The newly formed pupae are light green and gradually become brown. The pupae turn to dark black just before the moth emerges (Wilson, 1977). The moths are a grayish-brown color with a body length of $25 \mathrm{~mm}$. They have a wing span of about $40 \mathrm{~mm}$ and have a small elongate silver spot in the middle of each front wing (Greene, 1972).

Trichoplusia has two or three generations in the north and as many as six or seven in the south, with the number of worms usually increasing with each generation (Shorey, 1962).

Host Plants

The cabbage looper is a major pest of cruciferous plants, kale, 
cabbage, cauliflower and turnips. Trichoplusia larvae also attack lettuce, spinach, celery, parsley, potatoes, tomatoes, cotton, soy beans, watermelon, cantaloupe, squash, carnations, nasturtiums and mignonettes. This species has also been recorded feeding on many kinds of wild plants, such as California poppy, morning bride, chinch weed and wild lettuce (Talbert, 1953)).

\section{Damage}

The damage done by members of this species is quite variable, due to their wide host range. They can cause severe defoliation by feeding on vegetative tissue of their hosts. The last two instars are voracious feeders which can consume large quantities of plant tissue in a short time. They can injure most of the leaf surface available, and contaminate the remainder with their feces. Depending on the host, they also attack the flower buds of the plant or (in the case of cotton) destroy the "squares" (squares are the leaf-like bracts beneath the ovary). They can also cause damage by making scars on the surface of forming fruit (Atkins, 1960).

\section{Control Measures}

Cultural Control: The most important cultural practice to minimize cabbage looper populations is the removal of all plant waste from the field. In the case of cabbage, the disposal of discarded 
plants is very essential immediately following thinning (Thompson, 1957).

Chemical Control: The current insecticides recommended by Crop Protection Chemicals Reference (Wiley, 1991) to use against Trichoplusia larvae are Ambush and Asana which are both pyrethroids, Cythion which is an organophosphate and Lannate which is a carbamate.

Biological Control: All stages of cabbage loopers are attacked by parasites and predators. Trichogramma mimutum oviposit in the eggs, tachinids oviposit in the larvae and pupae, and birds and bats attack the adults (Brogdon, 1970).

The application of Bacillus thuringiensis as a bacterial insecticide and the use of electrified traps baited with the synthetic sex-scents usually provide satisfactory control. There is also a nuclear polyhedrosis virus which is very effective against these insect pests, but it is highly specific, very slow acting, active for short periods of time, and is very sensitive to UV light (Hall, 1957).

\section{b. Agrotis ipsilon Hufangel}

Agrotis ipsilon is a cosmopolitan pest which is found in all 50 of the states in USA, and in Canada and Europe. It is a major but sporadic pest in the region of the American mid-west (Rings, 1976). These insects pass the winter as pupae and emerge from their pupal cases in the spring. Then they fly, mate, and lay eggs. Each female 
lays up to 1800 eggs singly or in small groups on the stems of grasses and weeds or on the leaves of plants (Busching, 1976). They may also lay their eggs in cracks in the ground. The newly laid eggs are white, circular in outline, blunt subconical in profile, 0.43 to 0.5 $\mathrm{mm}$ high and 0.55 to $0.58 \mathrm{~mm}$ broad (Harris, 1962). The eggs become tan to light brown as the incubation proceeds, and become dark brown just before hatching. The eggs hatch after five days. The young larvae are pale yellowish-green and the older ones are gray to brown, with lighter stripes. The full-grown larvae are about 40 to 45 $\mathrm{mm}$ long. The head capsule is brownish-black with two white spots. The prothoracic plate is a shining dark brown or black with faint yellowish-brown markings. On the top of each segment are four black marks with spines. Thoracic legs are yellowish brown and prolegs are pale gray. The larvae remain below the surface of the soil during the day, coiled in a ball, and feed mainly at night. After about two weeks, the full-grown larvae dig down several inches in the soil where they make cells in which they pupate. The pupae are reddish brown, about 17 to $22 \mathrm{~mm}$ long and five to six $\mathrm{mm}$ broad. The adult crawls out of the ground through the tunnel made earlier by the larvae going down. The adults have a grey body, with long, narrow and dark forewings which are marked with three black dashes. The wing span is 40 to $50 \mathrm{~mm}$. The hind wings are pearly, with a dark terminal fringe. The male moths have bipectinate antennae and females have filiform antennae (Crumb, 1929).

Agrotis has two generations a year as far north as Canada and 
two to four generations a year in the United States (Sechriest, 1967).

\section{Host Plants}

This is a serious pest of many herbaceous and woody plants. About 53 crops have been listed as the major hosts of Agrotis ipsilon (Rings, 1974). Cotton, rice, potatoes, tobacco, cereals, cabbage, sprouts, cauliflower and corn are most frequently attacked by this species.

\section{Damage}

Agrotis ipsilon larvae attack seedlings and young plants. They can eat entire plants, but sometimes just cut the plant off near the soil and drag it to their burrow in the soil. The young larvae feed on the leaves, and the older caterpillars often feed on roots and stems. Most damage caused by Agrotis ipsilon larvae occurs in spring and late summer in both Europe and America (Hill, 1983).

Control Measures

Cultural Control: Clean cultivation of fields is very important because black cutworm moths oviposit on weedy or grassy areas in the fields (Satterthwait, 1933).

Chemical Control: Some of the current chemical insecticides 
recommended by Crop Protection Chemicals Reference (Wiley, 1991) to use against Agrotis are Dyfonate and Lorsban which are both phosphates, and Mocap and Penncap which are organophsphates.

Biological Control: Zenillia formosa, and Meteorus leviventris are the two most important biological control agents of cutworm larvae. Bacillus thuringiensis, a biological insecticide, is also very effective against cutworms (Wilson, 1977).

\section{Rearing Nematodes}

My stock of infective juveniles of the Steinernema carpocapsae was obtained from Biosys (Palo Alto, California). They were sent on foams, in a polyethylene bag. The foams were rinsed five to seven times in distilled water to extract the nematodes. They were then kept refrigerated at $6^{\circ} \mathrm{C}$ with oxygenation in a flash jar in $0.1 \%$ formaldehyde solution to prevent the contamination of bacteria or fungi. The concentration was 200 or 400 nematodes per milliliter

The nematodes were reared in larvae of Galleria mellonella, according to the method described by Dutky (1964). The Galleria (wax moths) were also obtained from Biosys.

Inoculation was done by introducing approximately 400 infective juveniles into a $100 / 20 \mathrm{~mm}$ petri dish containing two filter papers (Whatman No. one) and 10 to 20 last-instar Galleria larvae. Dead larvae were placed in a nematode trap five to seven days after infection. The trap consisted of an inverted watch glass covered with 
a filter paper, on the bottom of a deep petri dish $(150 \times 15 \mathrm{~mm})$, with $0.1 \%$ formalin added so that the filter paper came in contact with the liquid. Dead larvae were placed on the filter paper, then the juvenile nematodes began migrating into the $0.1 \%$ formalin ten to twelve days after death of the larvae. The juveniles were harvested daily thereafter for five days and were kept at $10^{\circ} \mathrm{C}$ in a $250 \mathrm{ml}$ Erlenmeyer flasks with $0.1 \%$ formalin. The nematodes were then diluted with water or concentrated by centrifugation as needed.

Before experimentation, nematodes were rinsed three times in distilled water to remove traces of the formalin, and were examined for viability and concentration before each test. Examination of nematodes was done under a dissecting microscope, and they were discarded if mortality was higher than eight percent.

\section{Rearing Agrotis and Trichoplusia}

The black cutworm and cabbage looper larvae were obtained from Stauffer Chemical Company (Mountain View, California) to establish the colonies. Both colonies were raised under controlled conditions in a San Jose State University biology laboratory using a rearing method described by Robert G. Blenk (1985) and Richard H. Guy (1985).

The rearing incubator was maintained at $27^{\circ} \mathrm{C} \pm 3$ and $65 \%$ to $75 \%$ RH, with a 14 hours photophase. The adults were kept in cylindrical cages nine inches in diameter by twelve inches in height, which were 
made of $1 / 4$ inch mesh screen. The cabbage looper adults were fed on a $10 \%$ honey water solution and black cutworm adults were fed on a $30 \%$ honey water solution.

The eggs were collected daily in the afternoon, and were surface sterilized in a $10 \%$ formaldehyde solution for ten minutes to prevent transfer of bacterial, fungal and viral contamination from adult cages. They were then transferred to cups containing artificial diet, where they were kept until pupation. The pupae were surface sterilized in $10 \%$ bleach solution for ten minutes, to remove the silk and to prevent mold contamination.

The life cycle from egg to adult, at $27^{\circ} \mathrm{C} \pm 3$ and $65 \%$ to $75 \% \mathrm{RH}$, required about 22 to 27 days for cabbage loopers and about 34 to 42 days for black cutworms.

\section{The Experimental Plant}

The cabbage variety that was used for this project was Early Round Dutch. The seeds were planted in 11 by 21 inch flat containers and covered with about $1 / 4$ inch of super-soil. Fish emulsion was used as the fertilizer. They were kept in a greenhouse at San Jose State University.

Cabbages are attacked by many insects, which can be very destructive. The most important insect pests of cabbage are the cabbage looper, cutworm, green cabbage worm, cabbage maggot, southern cabbage butterfly, cross-striped cabbage worm, cabbage 
webworm, cabbage aphid and turnip aphid. Plant lice and harlequin bugs are also considered to be serious pests (Cress, 1976).

\section{Tests}

The tests were designed to determine effects of moisture and natural sunlight (summer) on the efficacy of nematodes as control agents of Agrotis ipsilon and Trichoplusia ni.

\section{a. Trichoplusia ni}

Five series of experiments were done with Trichoplusia larvae. Each series contained two tests. Twenty larvae were used for the first test, and thirty larvae were used for the confirmation test. These experiments were made on cut cabbage leaves. Each leaf was placed in a 60 by $15 \mathrm{~mm}$ petri dish with moist cotton around the stem to prevent rapid dehydration. Half of a milliliter of nematode suspension, containing approximately 1400 nematodes, was pipetted onto the surface of each leaf.

The first series was done to determine the nematode tolerance to desiccation and was conducted in the laboratory. In this series nematodes on the leaf surface were exposed to room conditions (24$26^{\circ} \mathrm{C}$ and $\left.55-65 \% \mathrm{RH}\right)$. They were kept under the hood to allow the water to evaporate from the leaf surface. For the first group of leaves, the water was allowed to evaporate until only a thin film of 
water remained on the leaf surface. For the second group, the water was allowed to evaporate until the leaves became relatively dry. The remaining experiments were conducted outdoors to determine the efficacy of nematcdes after they have been exposed to morning sunlight versus late afternoon sunlight and with high moisture versus low moisture on the leaves. Another objective of these experiments was to determine what amounts of exposure to sunshine would decrease nematode efficacy by $75 \%$ or more.

The second series of experiments was conducted at 11:30 in the morning (higher sunlight intensity), and the third series was carried out two hours prior to sunset (lower sunlight intensity). In both cases nematodes on the leaves were exposed to direct sunlight in open dishes outdoors for periods ranging from four to 192 minutes. The samples were fully exposed to the sun during all exposures. Temperature and sunlight intensity were recorded at the start and at the end of the periods of nematode exposure to morning sun. Sunlight intensity was recorded at the start of the late afternoon tests using a model LI-185B Radiometer (LI-COR, Inc, Products).

The fourth and fifth series were similar to the other series except that the water was first allowed to evaporate until only a thin film of water remained on the leaf surface, before the samples were exposed to the sun.

Immediately after each period of nematode exposure (on the leaves) to sunlight, one third-instar larva of cabbage looper was placed on the nematode-infected leaf in each petri dish. The head 
capsules were measured, to determine the Trichoplusia instars. They were examined under a binocular microscope fitted with a micrometer eyepiece. McEwens' (1960) description was used to determine which instars were involved. The samples were then covered with aluminum foil and incubated at $27^{\circ} \mathrm{C}$ in the dark. After 48 hours, the amount of cabbage leaf consumed by cabbage loopers was recorded. The following guidelines were used in evaluating leaf consumption:

$0 \%=$ No feeding, $25 \%=$ Leaf partially consumed, $50 \%=\mathrm{Up}$ to half of the leaf consumed, $75 \%=$ More than half of the leaf consumed, $100 \%=$ The entire leaf consumed.

Intermediate amounts of consumption were estimated visually.

Each larva was then transferred to a separate one-ounce cup containing artificial diet. The procedure described by Adkisson (1960) was used to make the artificial diet. The ingredients that had been used to make the diet were wheat germ, agar, sorbic acid, salt mixture, 'casein, vitamin, methyl paraben, formaldehyde and water.

Seven days after the actual date of the test, dead larvae were examined for mortality and dissected for analysis of nematode infection. The efficacy of nematodes was determined by the number of Trichoplusia that had been killed by the nematodes. The data were analyzed by the t-test.

Two sets of caterpillar "controls" were compared with test 
caterpillars in each of the five series of experiments. The first set of caterpillar "controls" had adequate water, but no sun (control). ${ }^{1}$ The second set of caterpillar "controls" had water plus nematodes, but no sun (control). ${ }^{2}$ The test caterpillars were exposed to varying amount of sunlight. Both "control" groups of nematodes were also maintained in the laboratory, without exposure to the sun.

\section{b. Agrotis ipsilon}

Three series of experiments were conducted with soil-inhabiting Agrotis larvae. Each series of tests consisted of five replicates of a "control" and a nematode treatment. Each test was run twice. These experiments were done in 11-by-21-inch plastic flats. Each flat was filled with three kilograms of super-soil. Soil was stored at room temperature at least seven days prior to the experimentation date. Twenty seedling cabbage plants were transferred into each container. After transplanting, $1500 \mathrm{ml}$ of water was sprayed onto the soil surface, then $0.1 \mathrm{ml}$ of nematode suspension, containing approximately 10,000 nematodes, was poured around the base of each plant. After each treatment five third-instar cutworm larvae (Harris, 1962) were placed on the surface of the soil on each flat. After 48 hours, $500 \mathrm{ml}$ of water was added to each flat. The larvae were removed from the soil and were examined for mortality and nematode infection after another 48 hours.

The first series of experiments was done in the laboratory under 
controlled conditions $\left(27^{\circ} \mathrm{C} \pm 3,60\right.$ to $\left.65 \% \mathrm{RH}\right)$ to find out what the performance of nematodes would be with regard to moisture in the soil. For comparison, one of the treatments, was performed without adding any water.

The second and third series were similar to the first one except that they were performed outdoors and water was added to all treatments. The purpose of these two series was to determine the performance of nematodes in the soil at high and low sunlight intensity. The second series was conducted at 11:30 in the morning, when sunlight intensity was high, and the third series was done two hours prior to sunset, when sunlight intensity was lower.

The data were analyzed by the t-test. Effectiveness of the nematodes was determined by the extent of mortality of Agrotis larvae and by evaluating the extent of caterpillar injury to cabbage plants after four days. The following guidelines were used in evaluating the cutworm damage to cabbage plants:

$0 \%=$ No feeding, $25 \%=$ Seedling with leaf partially consumed, $50 \%=\mathrm{Up}$ to half of seedling consumed, $75 \%=$ More than half of the seedling consumed, $100 \%=$ The whole seedling consumed (or cut off). Intermediate amounts of damage were estimated visually.

The experiments which were done outdoors, took place in open areas. Temperature was recorded hourly, and sunlight intensity was measured hourly for the first four hours in the morning tests, but 
sunlight intensity was only taken at the time of application of nematodes in the late afternoon series. 


\section{Results and Conclusions}

Five series of experiments were conducted with Trichoplusia (Experiments \#1 through \#5) and three series were conducted with Agrotis (Experiments \#6 through \#8). Each experiment was run twice to confirm the results. The first one was simply called the first test, and the second one was called the confirmation test.

\section{Trichoplusia ni}

Experiment \#1

The results showing percent mortality of cabbage loopers caused by nematodes are presented in Tables 1 and 3. Standard deviations and means of cabbage leaf volume consumed by the third instar cabbage loopers are recorded in Tables 2 and 4 for this experiment.

In this series of tests, two groups of leaves (details on page 22 and 23) containing nematodes were exposed to laboratory conditions, before the larvae were placed on the leaves. This experiment indicates the importance of moisture on the foliage for effective control of Trichoplusia. As the results show, efficacy of nematodes depended on the amount of moisture on the leaf surface. A high level of control was achieved by nematodes when more moisture was present $(83.3 \%$ to $85 \%$ of Trichoplusia mortality); however, after the water evaporated from the leaf surface and it became relatively dry, the desiccation effectively reduced the efficacy of nematodes and 
they became $100 \%$ noneffective (Figures 1 and 2 ).

There was no mortality in the controls ${ }^{1}$ (caterpillars exposed to watered leaves, but no nematodes). There was $100 \%$ infection in the controls $^{2}$ (caterpillars exposed to watered leaves and nematodes) in both the first and confirmation tests. All of the dead (treated) larvae contained nematodes.

The mean percent mortality of cabbage loopers differed significantly between the controls ${ }^{1}$ (first test, $0 \%$; confirmation test, $0 \%$ ) and the larvae with moisturized nematodes (first test, 85\%; confirmation test, 83.3\%) after seven days of scoring $(\mathrm{p}<0.05)$. Mean mortality did not differ significantly between the controls ${ }^{1}$ (first test, $0 \%$; confirmation test, $0 \%$ ) and the relatively dry nematodes (first test, $0 \%$; confirmation test, $0 \%$ ) after seven days. The t-test showed that the the most significant difference in the tested nematodes was due to the differences in moisture.

Experiment \#2

The results showing percent mortality of cabbage loopers caused by nematodes are presented in Tables 5 and 7 . Standard deviations and means of cabbage leaf volume consumed by the third instar cabbage loopers are recorded in Tables 6 and 8 for experiment \#2.

In this series of tests, the leaves containing nematodes were exposed to morning sunlight (with sunlight intensity of 1650 Einstein) for 4 minutes, 8 minutes, 16 minutes, 32 minutes or 64 minutes, respectively, before the larvae were placed on the leaves. 
The longer the nematodes had been in the sunlight the less effective they became. In the first test the percent mortality of cabbage loopers was $90 \%$ when nematodes had been in sunlight for 4 minutes, but $85 \%$ after they had been in sunlight for 8 and 16 minutes. Only $65 \%$ mortality of loopers resulted from nematodes that had been exposed to morning sunlight for 32 minutes, and there was no mortality caused by nematodes that were exposed to sunlight for 64 minutes. In the confirmation test, the percent mortality of cabbage loopers caused by nematodes after exposure to morning sun for 16,32 and 64 minutes, respectively, was $93.3 \%, 66.7 \%$ and $3.3 \%$. There was no mortality in the controls ${ }^{1}$ (caterpillars exposed to watered leaves, but no nematodes). There was $100 \%$ infection in the controls $^{2}$ (caterpillars exposed to watered leaves and nematodes) in both the first and confirmation tests. All of the dead (treated) larvae contained nematodes.

Experiments to determine the effects of sunlight on the nematodes indicated that nematode efficacy was significantly reduced by exposure to morning sunlight (1650 Einstein). The nematodes that had been exposed to morning sunlight killed fewer Trichoplusia larvae than those nematodes that were never exposed to the sun. Larval mortality ranged from $100 \%$ to $0 \%$, indicating that with increased exposure time to morning sunlight the ability of nematodes to control Trichoplusia decreased. Efficacy remained high after up to 16 minutes of exposure time to the morning sunlight, but was adversely effected after nematodes were exposed to the 
morning sunlight for 32 minutes (mortality of Trichoplusia was reduced to $65 \%$ and $66.7 \%$ ). The nematodes became almost completely ineffective after 64 minutes of exposure to morning sunlight (Figures 3 and 4).

A t-test revealed that there were significant differences between the controls ${ }^{1}$ and the larvae treated with nematodes that had been exposed to morning sunlight for up to 32 minutes $(p<0.05)$. There were no significant differences however, between the controls ${ }^{1}$ and the larvae treated with nematodes that had been exposed to morning sunlight for 64 minutes ( $p>0.05$ ).

\section{Experiment \#3}

Tables 9 and 11 show the percent mortality of cabbage loopers caused by nematodes after they had been exposed to late afternoon sunlight (two hours prior to sunset, with sunlight intensity of 680 Einstein). Means and standard deviations of cabbage leaf volume consumed by cabbage loopers are recorded in Tables 10 and 12 .

As the data of both the first and confirmation tests show, 100 percent mortality of black cutworms was caused by the nematodes that had been exposed to late afternoon sunlight for 32 and 64 minutes, respectively. The percent mortality of cabbage loopers caused by the nematodes that had been exposed to late afternoon sunlight for 128 and 192 minutes, respectively, was $75 \%$ and $10 \%$ in the first test, and $80 \%$ and $23.3 \%$ in the confirmation test.

There was no mortality in the controls ${ }^{1}$ (caterpillars exposed to 
watered leaves, but no nematodes) in the first test. There was $6.7 \%$ mortality induced by virus in the controls 1 in the confirmation test. There was $100 \%$ infection in the controls ${ }^{2}$ (caterpillars exposed to watered leaves and nematodes) for both tests. All of the dead (treated) larvae contained nematodes.

The t-test indicated that there were significant differences between the controls ${ }^{1}$ and the larvae treated with nematodes which had been exposed to late afternoon sunlight for up to 128 minutes $(p<0.05)$. There were no significant differences however, between the controls $^{1}$ and the larvae treated with nematodes which were similarly exposed for 192 minutes ( $p>0.05$ ).

This experiment shows that 64 minutes of late afternoon sunlight (680 Einstein) exposure did not reduce nematodes' efficacy in controlling Trichoplusia larvae. The mortality rate caused by nematodes after exposure to the sun for 64 minutes was the same as for the nematodes that had not been exposed to sunshine. The efficacy was considerably reduced after 128 minutes of exposure (75\% to $80 \%$ Trichoplusia mortality, compared with $100 \%$ mortality induced by unexposed nematodes). A very significant loss in efficacy resulted after 192 minutes of nematode exposure to the late afternoon sunlight (only $10 \%$ to $23.3 \%$ Trichoplusia mortality). The data suggest that nematodes applied to foliage in late afternoon can achieve a high level of caterpillar control only within the first two hours after application, and only if optimum moisture is present (Figures 5 and 6). 
A comparison between experiments \#2 and \#3 demonstrates that nematodes that have been exposed to morning sunlight (1650 Einstein) for 64 minutes controlled only $0 \%$ to $3.3 \%$ of the cabbage looper larvae, whereas nematodes that have been exposed to late afternoon sunlight (680 Einstein) for the same length of time controlled $100 \%$ of the larvae. These results show that nematodes are very susceptible to morning sunlight, and that they will therefore be more efficient in killing the cabbage loopers if they are applied in late afternoon.

\section{Experiment \#4}

The results showing percent mortality of cabbage loopers caused by nematodes are presented in Tables 13 and 15. Standard deviations and means of cabbage leaf volume consumed by the third instar cabbage loopers are recorded in Tables 14 and 16 for experiment \#4.

In this series of tests, the leaves containing nematodes were exposed to morning sunlight (with sunlight intensity of 1680 Einstein) for $4,8,16$ or 32 minutes, respectively, after the water was evaporated from the leaf surface (only a thin film of water was available on the leaf). In the first test the percent mortality of cabbage loopers was $80 \%$ when nematodes had been in sunlight for 4 and 8 minutes, but $60 \%$ after they had been in sunlight for 16 minutes. Only $10 \%$ mortality of loopers resulted from the nematodes that had been exposed to morning sunlight for 32 minutes. In the 
confirmation test, the percent mortality of cabbage loopers caused by nematodes after exposure to late afternoon sunlight for 8,16 and 32 minutes, respectively, was $73.3 \%, 56.7 \%$ and $10 \%$.

There was $5 \%$ mortality induced by virus in the controls 1 (caterpillars exposed to watered leaves, but no nematodes). There was $90 \%$ infection in the controls $^{2}$ (caterpillars exposed to watered leaves and nematode) in the first test. There was no mortality in the controls $^{1}$ and $83.3 \%$ infection in the controls ${ }^{2}$ in the confirmation test. All of the dead (treated) larvae contained nematodes.

The t-test revealed that there were significant differences between efficacy of the controls ${ }^{1}$ and the larvae treated with nematodes which had been exposed to morning sunlight for 4,8 and 16 minutes $(p<0.05)$. However, no significant difference was observed between the controls 1 and the larvae treated with nematodes which were exposed to sunlight for 32 minutes ( $p>0.05$ ).

The results obtained by exposing nematodes to natural morning sunlight (1680 Einstein) after the water was evaporated from the leaf surface revealed that, the combined effects of the two factors resulted in a rapid decrease of the nematodes' efficacy. The efficacy was moderately high only within the first eight minutes of exposure to morning sunlight (causing $73.3 \%$ to $80 \%$ Trichoplusia mortality). Nematode efficacy was considerably reduced after 16 minutes of exposure to the morning sunlight (causing only $56.7 \%$ to $60 \%$ Trichoplusia mortality). There was an even more drastic decline in the efficacy of nematodes that had been exposed to sunlight for 32 
minutes (they caused only $10 \%$ Trichoplusia mortality) (Figures 7 and 8).

A comparison between the data from experiments \#2 and \#4 demonstrates that the loss of efficacy was attributed mainly to sunlight (Experiment \#2), but when lack of moisture provided an additional stress factor (Experiment \#4) nematodes lost their infectivity at a much faster rate. Nematodes controlled $65 \%$ to $66.7 \%$ of loopers after they had been exposed to the sun for 32 minutes in experiment \#2 (with optimum moisture present), whereas in experiment \#4 they controlled only $10 \%$ of larvae after they had been exposed to the sun for the same length of time, but under arid conditions.

\section{Experiment \#5}

Tables 17 and 19 indicate the percent mortality of cabbage loopers treated with nematodes which had been exposed to late afternoon sunlight (two hours prior to sunset, with sunlight intensity of 730 Einstein) and with only a thin film of water available on the leaf. Means and standard deviations of cabbage leaf volume consumed by cabbage loopers are recorded in Tables 18 and 20.

Nematodes that had been previously exposed to late afternoon sunlight (730 Einstein) for periods of $16,32,64$ or 128 minutes killed $85 \%, 75 \%, 30 \%$ and $20 \%$ of cabbage loopers, respectively, in the first test. In the confirmation test the percent mortality of cabbage loopers caused by nematodes that had been exposed to late 
afternoon sunlight for $16,32,64$ and 128 minutes, respectively, was $90 \%, 80 \%, 36.7 \%$ and $23.3 \%$, respectively.

There was $5 \%$ mortality induced by virus in the controls 1 (caterpillars exposed to watered leaves, but no nematodes). There was $85 \%$ infection in those controls ${ }^{2}$ (caterpillars exposed to watered leaves and nematodes) in the first test. There was no mortality in the controls $\mathrm{s}^{1}$ and $93.3 \%$ infection in the controls ${ }^{2}$ in the confirmation test. All of the dead (treated) larvae contained nematodes.

The t-test indicated that there were significant differences between the controls 1 and the larvae treated with nematodes which had been exposed to late afternoon sunlight for up to 64 minutes $(p<0.05)$. There were no significant differences between the controls 1 and the larvae treated with nematodes which were similarly exposed for 128 minutes ( $p>0.05$ ).

As the results indicate, little change in efficacy of nematodes was detected after the nematodes had been exposed to late afternoon sunlight (730 Einstein) for up to 32 minutes. Mortality caused by those nematodes ranged from $75 \%$ to $90 \%$. The efficacy declined as the exposure time increased, therefore longer sunlight exposure times resulted in lowered mortality of Trichoplusia. Efficacy began to decline dramatically when the length of time of sunlight exposure was 64 minutes or longer, and mortality caused by those nematodes did not exceed $36.7 \%$, while nematodes that were never exposed to sunshine caused $85 \%$ to $93.3 \%$ mortality (Figures 9 and 10).

Comparing experiments $\# 3$ and \#5, nematodes that were 
exposed to late afternoon sunlight for 64 minutes with optimum moisture available, were more efficient in killing Trichoplusia larvae (100\% mortality) than were the nematodes with the same sunlight exposure time but with only a thin film of water present (30\% to $36.7 \%$ mortality). The data suggest that the $63.3 \%$ to $70 \%$ decrease in efficacy of nematodes was due to the desiccation of the nematodes in experiment \#5.

\section{Agrotis ipsilon}

During these experiments with Agrotis ipsilon, the weather was sunny, clear to partly cloudy, and there was no wind. The highest temperatures did not exceed $26^{\circ} \mathrm{C}$, and the lowest temperatures did not go below $6^{\circ} \mathrm{C}$. The mean temperature for the four days during each experiment is included in the Tables.

\section{Experiment \#6}

Mortality of black cutworms treated with nematodes under the control conditions $\left(27^{\circ} \mathrm{C}, 60\right.$ to $\left.65 \% \mathrm{RH}\right)$ are presented in Tables 21 and 22. As the tables of both tests show, $100 \%$ mortality of cutworms was achieved when they were treated with nematodes under the confined conditions when moisture was available at the time of introduction. The percent mortality of black cutworms caused by nematodes applied to dry soil were $40 \%, 60 \%, 40 \%, 40 \%$ and $20 \%$ (mean $=40.0)$ in the first test. In the confirmation test the percent 
mortality of black cutworms were $60 \%, 40 \%, 40 \%, 60 \%$ and $40 \%$ (mean $=48.0)$. All of the dead (treated) cutworms contained reproducing nematodes. There was $4 \%$ mortality (virus infection) in the controls of the first test and no mortality in the controls of the confirmation test.

Estimates of the percent damage caused by cutworms to cabbage plants in the first test with untreated soil were: $100 \%, 77.5 \%, 100 \%$, $95 \%$ and $82.5 \%$ (mean $=91.00$ ); with treated moist soil: $16.25 \%$, $8.75 \%, 13.75 \%, 15 \%$ and $11.25 \%$ (mean $=13.00$ ) and with treated dry soil: $56.25 \%, 45 \%, 55 \%, 48.75 \%$ and $70 \%$ (mean $=55.00)($ Table 23$)$. In the confirmation test, estimates of the percent damage with untreated soil were: $77.5 \%, 100 \%, 76.25 \%$ and $83.75 \%$ (mean $=87.50)$; with treated moist soil: $15 \%, 13.75 \%, 11.25 \%, 12.5 \%$ and $10 \%$ (mean $=$ $12.50)$ and with treated dry soil: $43.75 \%, 52.50 \%, 56.25 \%, 50 \%$ and $53.75 \%($ mean $=51.25)($ Table 24$)$.

The t-test showed that there were significant differences for mortality and cutworm damage between the controls and those treated with nematodes applied to moist soil $(\mathrm{p}<0.05)$, whereas there were no significant differences between the controls and those treated with nematodes applied to dry soil in both the first and confirmation tests $(p>0.05)$.

Results of this experiment show that the efficacy of nematodes was the greatest when the soil was moist. A very high control of cutworms by the nematodes was achieved (100\% mortality) under the confined conditions when nematodes were applied to moist soil 
(Figures 11 and 12). Nematodes were less effective when they were applied to dry soil, controlling only $40 \%$ to $48 \%$ of the Agrotis larvae. This $52 \%$ to $60 \%$ reduction in the mortality of Agrotis was correlated with the insufficient moisture content of soil. Moisture is a major requirement factor for nematodes to be highly effective. Data also indicate that damage caused by black cutworms was significantly reduced in the moist trays treated with nematodes, compared to damage caused by cutworms in the control groups. The amount of plant damage in the dry trays treated with nematodes was not significantly lower than that caused by the controls. This test proved that nematode treatments protected seedlings from cutworm damage when the soil moisture was optimum (Figures 13 and 14).

\section{Experiment \#7}

The percent mortality of black cutworms caused by nematodes applied in the morning (with sunlight intensity of 1710 Einstein) were $40 \%, 20 \%, 0 \%, 0 \%$ and $40 \%$ (mean $=20.0$ ) (Table 25) in the first test. In the confirmation test the percent mortality of black cutworms were $40 \%, 40 \%, 20 \%, 0 \%$ and $40 \%$ (mean $=28.0)$ (Table 26). All of the dead (treated) cutworms contained reproducing nematodes. There was no mortality in the controls for either first or the confirmation tests.

Estimates of the percent damage caused by black cutworms to cabbage plants in the first test with untreated soil were: $80 \%, 71.25 \%$, $81.25 \%$ and $78.75 \%($ mean $=78.50)$ and with treated soil: $51.25 \%$, 
$61.25 \%, 70 \%, 85 \%$ and $58.75 \%($ mean $=65.25)$ (Table 27). In the confirmation test, estimates of the percent damage for untreated soil were: $85 \%, 75 \%, 78.75 \%, 83.75 \%$ and $80 \%$ (mean= 80.50 ) and for treated soil: $50 \%, 58.75 \%, 73.75 \%, 78.75 \%$ and $55 \%($ mean $=63.25)$ (Table 28).

The t-test revealed that there were no significant differences between the controls and those treated with nematodes applied in the morning, for mortality and cutworm damage in either the first or the confirmation tests $(p>0.05)$.

The data from this experiment indicate that the factor responsible for decreased efficacy of nematodes applied in the soil to control Agrotis was the sunlight (Figures 15 and 16). Steinernema carpocapsae controlled only $20 \%$ to $28 \%$ of Agrotis larvae when applied in the morning (1710 Einstein). This test also indicates that nematode treatments showed some potential for protecting seedlings from cutworm injury but it was not very significant (Figures 17 and 18).

\section{Experiment \#8}

The percentages of mortality of black cutworms caused by nematodes applied in late afternoon (two hours prior to sunset, with sunlight intensity of 705 Einstein) were 100\%, 100\%, 100\%, 100\% and $60 \%$ (mean $=92.0$ ) in the first test. In the confirmation test the percentages of mortality were $80 \%, 100 \%, 100 \%, 100 \%$ and $60 \%$ $($ mean $=88.0)($ Table 29$)$. All of the dead (treated) cutworms 
contained reproducing nematodes. There was no mortality in the controls of first test and 4\% mortality (virus infection) in the controls of the confirmation test.

Estimates of the damage caused by cutworms to cabbage plants in the first test with untreated soil were: $88.75 \%, 93.75 \%, 85 \%, 82.5 \%$ and $77.5 \%$ (mean $=85.50$ ) and with treated soil: $18.75 \%, 11.25 \%$, $18.75 \%, 16.25 \%$ and $20 \%($ mean $=17.00)($ Table 31$)$. In the confirmation test, estimates of the damage with untreated soil were: $72.50 \%, 85 \%, 78.75 \%, 80 \%$ and $91.25 \%$ (mean $=81.50$ ) and with treated soil: $21.25 \%, 12.5 \%, 18.75 \%, 20 \%$ and $18.75 \%($ mean $=18.25)$ (Table 32).

The t-test showed that there were significant differences in mortality and cutworm damage between the the controls and those treated with nematodes applied in the late afternoon in both the first and the confirmation tests $(\mathrm{p}<0.05)$.

This experiment was performed to determine the importance of protecting the nematodes from sunlight. Nematode treatments caused a significant cutworms mortality ( $88 \%$ to $92 \%$ ) when they were applied in the late afternoon (705 Einstein), compared to untreated cutworms. Results also showed that the nematode applications in the afternoon caused a significant decrease in plant damage, compared to untreated plants (Figures 21 and 22).

A comparison between experiments \#7 and \#8 demonstrates that applications of nematodes during late afternoon provided a much higher level of control (Figures 21 and 22) than applications 
during the morning (Figures 15 and 16). The data suggest that nematode effectiveness against Agrotis larvae was improved substantially by late afternoon applications. 


\section{E. Discussion}

Entomogenous nematodes have been evaluated as biological control agents for many insect pests (Webster, 1972). It has been reported that nematodes can provide control comparable with chemical insecticides (Georgis, 1991). That is true only when environmental conditions (temperature, moisture, sunlight) are favorable for nematode motility and infectivity. The objective of this study was to assess the efficacy of Steinernema carpocapsae in controlling two insect pests in two different habitats (a foliagefeeding caterpillar and a soil-inhabiting caterpillar).

The observed effect of sunlight and moisture on nematode efficacy for control of Trichoplusia and Agrotis led to the conclusions that nematodes rapidly lose their efficacy when exposed to sunlight, and also that efficacy is dependent on moisture availability.

My data indicate that Steinernema carpocapsae is extremely sensitive to desiccation and natural sunlight. Some conditions under which the nematodes were applied affected their efficacy as biological control agents. It is very important that these nematodes be applied to habitats in which adequate moisture is available, if caterpillar control is desired (Experiment \#6). This enhances nematode survival and improves access to target zones. The timing of application is also very important. To avoid adverse temperatures and high sunlight intensity, the applications must be made either in early morning (Macvean, 1982) or in late afternoon (Experiment \#8). 
The present results encourage the use of Steinernema carpocapsae against soil-feeding caterpillars. Soil is the natural habitat for these nematodes, and it provides protection against environmental extremes.

The present results discourage the use of Steinernema carpocapsae against leaf-feeding insects due to the poor persistence in the foliage environment. This is an important consideration in the utilization of nematodes for the control of insect pests. The nematodes frequently enter their host by the ingestion, so they must remain viable in the environment long enough to be consumed by the host. Nematodes on leaves, however, are only effective for a very short period of time (Experiment \#1). They are subjected there to rapid desiccation and are also destroyed by ultraviolet light.

From the results presented in this paper, it is clearly evident that these nematodes are more effective in controlling soil insect pests than leaf-feeding insects, unless the leaves are protected from adverse environmental factors. One of the important goals in the future is to increase the persistence and efficacy of these nematodes in the field. Developing new formulations might be a means of accomplishing this goal.

Many researchers have investigated methods of increasing nematode efficacy by using protective additives such as ultraviolet protectants (Gaugler, 1979) and evaporation retardants (Ignoffo, 1976). Most of these materials looked promising in the laboratory, but in actual practice the results have been inconsistent and 
unsatisfactory in the field (Kaya, 1990).

The results of my experiments indicate the importance of being aware of the conditions that adversely affect entomogenous nematodes, and illustrate how effective the nematodes can be if they are properly administered. If protected from desiccation and ultraviolet light by evaporation retardants and ultraviolet protectants, nematodes can obviously become even more valuable as effective weapons in the developing field of integrated pest management. 
Table 1

\section{Percent mortality of cabbage looper by nematodes when the diluent (water) was allowed to evaporate from the leaf surface.}

\begin{tabular}{|c|c|c|c|c|c|c|c|c|c|}
\hline $\begin{array}{l}\text { Treatment } \\
\text { Exposure }\end{array}$ & $\begin{array}{l}\# \\
\text { Larvae }\end{array}$ & $\begin{array}{l}\# \\
\text { Dead }\end{array}$ & $\begin{array}{l}\% \\
\text { Dead }\end{array}$ & $\begin{array}{l}\# \\
\text { Live }\end{array}$ & $\begin{array}{l}\% \\
\text { Live }\end{array}$ & $\begin{array}{l}\# \\
\text { Dead larvae } \\
\text { Containing } \\
\text { Nematodes }\end{array}$ & $\begin{array}{l}\% \\
\text { Dead larvae } \\
\text { Containing } \\
\text { Nematodes }\end{array}$ & Mean & S.D \\
\hline $\begin{array}{l}\text { Water } \\
\text { Control }^{1}\end{array}$ & 20 & 0 & 0 & 20 & 100 & 0 & 0 & 0.0 & 0.0 \\
\hline $\begin{array}{l}\text { Nematode } \\
\text { Control }^{2}\end{array}$ & 20 & 20 & 100 & 0 & 0 & 20 & 100 & 100.0 & 0.0 \\
\hline $\begin{array}{l}\text { Nematode } \\
\text { Moist }\end{array}$ & 20 & 17 & 85 & 3 & 15 & 17 & 100 & 85.0 & 36.6 \\
\hline $\begin{array}{l}\text { Nematode } \\
\text { Relatively } \\
\text { Dry }\end{array}$ & 20 & 0 & 0 & 20 & 100 & 0 & 0 & 0.0 & 0.0 \\
\hline
\end{tabular}

\section{Mean consumption of cabbage leaves by cabbage looper}

Table 2

$\begin{array}{lllll}\text { Treatment } & \text { Water } & \text { Nematode } & \text { Nematode } & \text { Nematode } \\ \text { Exposure } & \text { Control } & & \text { Moist } & \text { Relatively dry } \\ \text { Mean } & 82.50 & 63.75 & 65.00 & 78.75 \\ \text { S.D } & 28.21 & 29.77 & 31.83 & 28.42\end{array}$

Experiment \#1 (first test)

Kept inside $\left(24-26^{\circ} \mathrm{C}, 55-65 \% \mathrm{RH}\right)$ 


\section{Percent mortality of cabbage looper by nematodes when the diluent (water) was allowed to evaporate from the leaf surface.}

Table 3

\begin{tabular}{|c|c|c|c|c|c|c|c|c|c|}
\hline $\begin{array}{l}\text { Treatment } \\
\text { Exposure }\end{array}$ & $\begin{array}{l}\# \\
\text { Larvae }\end{array}$ & $\begin{array}{l}\# \\
\text { Dead }\end{array}$ & $\begin{array}{l}\% \\
\text { Dead }\end{array}$ & $\begin{array}{l}\# \\
\text { Live }\end{array}$ & $\begin{array}{l}\% \\
\text { Live }\end{array}$ & $\begin{array}{l}\# \\
\text { Dead larvae } \\
\text { Containing } \\
\text { Nematodes }\end{array}$ & $\begin{array}{l}\% \\
\text { Dead larvae } \\
\text { Containing } \\
\text { Nematodes }\end{array}$ & Mean & S.D \\
\hline $\begin{array}{l}\text { Water } \\
\text { Control }\end{array}$ & 30 & 0 & 0 & 30 & 100 & 0 & 0 & 0.0 & 0.0 \\
\hline $\begin{array}{l}\text { Nematode } \\
\text { Control }^{2}\end{array}$ & 30 & 30 & 100 & 0 & 0 & 30 & 100 & 100.0 & 0.0 \\
\hline $\begin{array}{l}\text { Nematode } \\
\text { Moist }\end{array}$ & 30 & 25 & 83.3 & 5 & 16.7 & 25 & 100 & 83.3 & 37.9 \\
\hline $\begin{array}{l}\text { Nematode } \\
\text { Relatively } \\
\text { Dry }\end{array}$ & 30 & 0 & 0 & 30 & 100 & 0 & 0 & 0.0 & 0.0 \\
\hline \multicolumn{10}{|c|}{$\begin{array}{l}\text { Mean consumption of cabbage } \\
\text { leaves by cabbage looper }\end{array}$} \\
\hline $\begin{array}{l}\text { Treatment } \\
\text { Exposure }\end{array}$ & & $\begin{array}{l}\text { Nater } \\
\text { Control }\end{array}$ & & $\begin{array}{l}\text { Nema } \\
\text { Contr }\end{array}$ & & $\begin{array}{l}\text { Nematoc } \\
\text { Moist }\end{array}$ & & $\begin{array}{l}\text { Nematode } \\
\text { Relatively }\end{array}$ & dry \\
\hline Mean & & 1.67 & & 71.67 & & 76.67 & & 89.17 & \\
\hline S.D & & 7.78 & & 29.6 & & 29.31 & & 16.97 & \\
\hline
\end{tabular}

Experiment \#1 (confirmation test)

Kept inside $\left(24-26^{\circ} \mathrm{C}, 55-65 \% \mathrm{RH}\right)$ 


\section{Percent mortality of cabbage looper by nematodes exposed to morning sunlight.}

Table 5

\begin{tabular}{|c|c|c|c|c|c|c|c|c|c|}
\hline $\begin{array}{l}\text { Treatment } \\
\text { Exposure }\end{array}$ & $\begin{array}{l}\text { \# } \\
\text { Larvae }\end{array}$ & $\begin{array}{l}\# \\
\text { Dead }\end{array}$ & $\begin{array}{l}\% \\
\text { Dead }\end{array}$ & $\begin{array}{l}\# \\
\text { Live }\end{array}$ & $\begin{array}{l}\% \\
\text { Live }\end{array}$ & $\begin{array}{l}\# \\
\text { Dead larvae } \\
\text { Containing } \\
\text { Nematodes }\end{array}$ & $\begin{array}{l}\% \\
\text { Dead larvae } \\
\text { Containing } \\
\text { Nematodes }\end{array}$ & Mean & S.D \\
\hline $\begin{array}{l}\text { Water } \\
\text { Control }^{1} \\
\text { No sun }\end{array}$ & 20 & 0 & 0 & 20 & 100 & 0 & 0 & 0.0 & 0.0 \\
\hline $\begin{array}{l}\text { Nematode } \\
\text { Control }^{2} \\
\text { No sun }\end{array}$ & 20 & 20 & 100 & 0 & 0 & 20 & 100 & 100.0 & 0.0 \\
\hline $\begin{array}{l}\text { Nematode } \\
4 \text { min sun }\end{array}$ & 20 & 18 & 90 & 2 & 10 & 18 & 100 & 90.0 & 30.7 \\
\hline $\begin{array}{l}\text { Nematode } \\
8 \text { min sun }\end{array}$ & 20 & 17 & 85 & 3 & 15 & 17 & 100 & 85.0 & 36.6 \\
\hline $\begin{array}{l}\text { Nematode } \\
16 \text { min sun }\end{array}$ & 20 & 17 & 85 & 3 & 15 & 17 & 100 & 85.0 & 36.6 \\
\hline $\begin{array}{l}\text { Nematode } \\
32 \text { min sun }\end{array}$ & 20 & 13 & 65 & 7 & 35 & 13 & 100 & 65.0 & 48.9 \\
\hline $\begin{array}{l}\text { Nematode } \\
64 \text { min sun }\end{array}$ & 20 & 0 & 0 & 20 & 100 & 0 & 0 & 0.0 & 0.0 \\
\hline
\end{tabular}

\section{Mean consumption of cabbage leaves by cabbage looper}

Table 6

$\begin{array}{llllllll}\text { Treatment } & \text { Water } & \text { Nematode } & \text { Nematode } & \text { Nematode } & \text { Nematode } & \text { Nematode } & \text { Nematode } \\ \text { Exposure } & \begin{array}{l}\text { Control } \\ \text { Control }\end{array} & 4 \mathrm{~min} & 8 \mathrm{~min} & 16 \mathrm{~min} & 32 \mathrm{~min} & 64 \mathrm{~min} \\ \text { Mean } & 86.25 & 52.50 & 55.00 & 56.25 & 53.75 & 78.75 & 88.75 \\ \text { S.D } & 18.98 & 29.13 & 27.63 & 26.75 & 20.32 & 29.10 & 20.64\end{array}$

Experiment \#2 (first test)

Temperature at the time of start $28^{\circ} \mathrm{C}$; Temperature at the end $31^{\circ} \mathrm{C}$

Min $=$ minutes 


\section{Percent mortality of cabbage looper by nematodes exposed to morning sunlight.}

Table 7

\begin{tabular}{|c|c|c|c|c|c|c|c|c|c|}
\hline $\begin{array}{l}\text { Treatment } \\
\text { Exposure }\end{array}$ & $\begin{array}{l}\text { \# } \\
\text { Larvae }\end{array}$ & $\begin{array}{l}\# \\
\text { Dead }\end{array}$ & $\begin{array}{l}\% \\
\text { Dead }\end{array}$ & $\begin{array}{l}\# \\
\text { Live }\end{array}$ & $\begin{array}{l}\% \\
\text { Live }\end{array}$ & $\begin{array}{l}\text { \# } \\
\text { Dead larvae } \\
\text { Containing } \\
\text { Nematodes }\end{array}$ & $\begin{array}{l}\% \\
\text { Dead larvae } \\
\text { Containing } \\
\text { Nematodes }\end{array}$ & Mean & S.D \\
\hline $\begin{array}{l}\text { Water } \\
\text { Control }{ }^{1} \\
\text { No sun }\end{array}$ & 30 & 0 & 0 & 30 & 100 & 0 & 0 & 0.0 & 0.0 \\
\hline $\begin{array}{l}\text { Nematode } \\
\text { Control } 2 \\
\text { No sun }\end{array}$ & 30 & 30 & 100 & 0 & 0 & 30 & 100 & 100.0 & 0.0 \\
\hline $\begin{array}{l}\text { Nematode } \\
16 \text { min sun }\end{array}$ & 30 & 28 & 93.3 & 2 & 6.7 & 28 & 100 & 93.3 & 25.3 \\
\hline $\begin{array}{l}\text { Nematode } \\
32 \text { min sun }\end{array}$ & 30 & 20 & 66.7 & 10 & 33.3 & 20 & 100 & 66.7 & 47.9 \\
\hline $\begin{array}{l}\text { Nematode } \\
64 \text { min sun }\end{array}$ & 30 & 1 & 3.3 & 29 & 96.7 & 1 & 100 & 3.3 & 18.2 \\
\hline
\end{tabular}

\section{Mean consumption of cabbage leaves by cabbage looper}

Table 8

\begin{tabular}{|c|c|c|c|c|c|}
\hline Treatment & Water & Nematode & Nematode & Nematode & Nematode \\
\hline Exposure & Control $^{1}$ & Control ${ }^{2}$ & $16 \mathrm{~min}$ & $32 \mathrm{~min}$ & $64 \mathrm{~min}$ \\
\hline Mean & 95.00 & 74.17 & 74.17 & 79.17 & 91.67 \\
\hline S.D & 10.17 & 35.04 & 25.83 & 21.86 & 15.16 \\
\hline
\end{tabular}

Experiment \#2 (confirmation test)

Temperature at the time of start $25^{\circ} \mathrm{C}$; Temperature at the end $27^{\circ} \mathrm{C}$

Min $=$ minutes 
Table 9

\section{Percent mortality of cabbage looper by nematodes exposed to late afternoon sunlight.}

\begin{tabular}{|c|c|c|c|c|c|c|c|c|c|}
\hline $\begin{array}{l}\text { Treatment } \\
\text { Exposure }\end{array}$ & $\begin{array}{l}\# \\
\text { Larvae }\end{array}$ & $\begin{array}{l}\# \\
\text { Dead }\end{array}$ & $\begin{array}{l}\% \\
\text { Dead }\end{array}$ & $\begin{array}{l}\# \\
\text { Live }\end{array}$ & $\begin{array}{l}\% \\
\text { Live }\end{array}$ & $\begin{array}{l}\text { \# } \\
\text { Dead larvae } \\
\text { Containing } \\
\text { Nematodes }\end{array}$ & $\begin{array}{l}\% \\
\text { Dead larvae } \\
\text { Containing } \\
\text { Nematodes }\end{array}$ & Mean & S.D \\
\hline $\begin{array}{l}\text { Water } \\
\text { Control } 1 \\
\text { No sun }\end{array}$ & 20 & 0 & 0 & 20 & 100 & 0 & 0. & 0.0 & 0.0 \\
\hline $\begin{array}{l}\text { Nematode } \\
\text { Control }{ }^{2} \\
\text { No sun }\end{array}$ & 20 & 20 & 100 & 0 & 0 & 20 & 100 & 100.0 & 0.0 \\
\hline $\begin{array}{l}\text { Nematode } \\
32 \text { min sun }\end{array}$ & 20 & 20 & 100 & 0 & 0 & 20 & 100 & 100.0 & 0.0 \\
\hline $\begin{array}{l}\text { Nematode } \\
64 \text { min sun }\end{array}$ & 20 & 20 & 100 & 0 & 0 & 20 & 100 & 100.0 & 0.0 \\
\hline $\begin{array}{l}\text { Nematode } \\
128 \text { min sun }\end{array}$ & 20 & 15 & 75 & 5 & 25 & 15 & 100 & 75.0 & 44.4 \\
\hline $\begin{array}{l}\text { Nematode } \\
192 \text { min sun }\end{array}$ & 20 & 2 & 10 & 18 & 90 & 2 & 100 & 10.0 & 30.7 \\
\hline \multicolumn{10}{|c|}{$\begin{array}{l}\text { Mean consumption of cabbage } \\
\text { leaves by cabbage looper }\end{array}$} \\
\hline $\begin{array}{l}\text { Treatment } \\
\text { Exposure }\end{array}$ & $\begin{array}{l}\text { Water } \\
\text { Control } 1\end{array}$ & & $\begin{array}{l}\text { Nematode } \\
\text { Control }^{2}\end{array}$ & & min & $\begin{array}{l}\text { Nematode } \\
64 \mathrm{~min}\end{array}$ & $\begin{array}{l}\text { Nematode } \\
128 \min \end{array}$ & $\begin{array}{l}\text { Nema } \\
192 n\end{array}$ & $\min$ \\
\hline Mean & 86.25 & & 68.75 & 60. & & 60.00 & 70.00 & 82.50 & \\
\hline S.D & 26.64 & & 27.95 & 31. & & 29.69 & 28.79 & 25.78 & \\
\hline
\end{tabular}

Experiment \#3 (first test)

Temperature at the time of start $27^{\circ} \mathrm{C}$; Temperature at the end $18^{\circ} \mathrm{C}$

Min $=$ minutes 
Table 11

\section{Percent mortality of cabbage looper by nematodes exposed to late afternoon sunlight.}

\begin{tabular}{|c|c|c|c|c|c|c|c|c|c|}
\hline $\begin{array}{l}\text { Treatment } \\
\text { Exposure }\end{array}$ & $\begin{array}{l}\# \\
\text { Larvae }\end{array}$ & $\begin{array}{l}\# \\
\text { Dead }\end{array}$ & $\begin{array}{l}\% \\
\text { Dead }\end{array}$ & $\begin{array}{l}\# \\
\text { Live }\end{array}$ & $\begin{array}{l}\% \\
\text { Live }\end{array}$ & $\begin{array}{l}\text { \# } \\
\text { Dead larvae } \\
\text { Containing } \\
\text { Nematodes }\end{array}$ & $\begin{array}{l}\% \\
\text { Dead larvae } \\
\text { Containing } \\
\text { Nematodes }\end{array}$ & Mean & S.D \\
\hline $\begin{array}{l}\text { Water } \\
\text { Control }{ }^{1} \\
\text { No sun }\end{array}$ & 30 & 2 & 6.7 & 28 & 93.3 & 0 & 0 & 6.7 & 25.3 \\
\hline $\begin{array}{l}\text { Nematode } \\
\text { Control } \\
\text { No sun }\end{array}$ & 30 & 30 & 100 & 0 & 0 & 30 & 100 & 100.0 & 0.0 \\
\hline $\begin{array}{l}\text { Nematode } \\
64 \text { min sun }\end{array}$ & 30 & 30 & 100 & 0 & 0 & 30 & 100 & 100.0 & 0.0 \\
\hline $\begin{array}{l}\text { Nematode } \\
128 \text { min sun }\end{array}$ & 30 & 24 & 80 & 6 & 20 & 24 & 100 & 80.0 & 40.6 \\
\hline $\begin{array}{l}\text { Nematode } \\
192 \text { min sun }\end{array}$ & 30 & 7 & 23.3 & 23 & 76.7 & 7 & 100 & 23.3 & 43.0 \\
\hline \multicolumn{10}{|c|}{$\begin{array}{l}\text { Mean consumption of cabbage } \\
\text { leaves by cabbage looper }\end{array}$} \\
\hline $\begin{array}{l}\text { Treatment } \\
\text { Exposure }\end{array}$ & & $\begin{array}{l}\text { Water } \\
\text { Control }^{1}\end{array}$ & & $\begin{array}{l}\text { Nematode } \\
\text { Control }^{2}\end{array}$ & & $\begin{array}{l}\text { Nematode } \\
64 \mathrm{~min}\end{array}$ & $\begin{array}{l}\text { Nematode } \\
128 \mathrm{~min}\end{array}$ & $\begin{array}{l}\text { Nema } \\
192 r\end{array}$ & min \\
\hline Mean & & 87.50 & & 75.83 & & 72.50 & 80.83 & 81.67 & \\
\hline S.D & & 26.87 & & 31.13 & & 28.12 & 25.16 & 26.21 & \\
\hline
\end{tabular}

Experiment \#3 (confirmation test)

Temperature at the time of start $27^{\circ} \mathrm{C}$; Temperature at the end $19^{\circ} \mathrm{C}$

Min $=$ minutes 
Percent mortality of cabbage looper by nematodes exposed to morning sunlight when the water was allowed

Table 13 to evaporate from the leaf surface.

\begin{tabular}{|c|c|c|c|c|c|c|c|c|c|}
\hline $\begin{array}{l}\text { Treatment } \\
\text { Exposure }\end{array}$ & $\begin{array}{l}\# \\
\text { Larvae }\end{array}$ & $\begin{array}{l}\# \\
\text { Dead }\end{array}$ & $\begin{array}{l}\% \\
\text { Dead }\end{array}$ & $\begin{array}{l}\# \\
\text { Live }\end{array}$ & $\begin{array}{l}\% \\
\text { Live }\end{array}$ & $\begin{array}{l}\# \\
\text { Dead larvae } \\
\text { Containing } \\
\text { Nematodes }\end{array}$ & $\begin{array}{l}\% \\
\text { Dead larvae } \\
\text { Containing } \\
\text { Nematodes }\end{array}$ & Mean & S.D \\
\hline $\begin{array}{l}\text { Water } \\
\text { Control }^{1} \\
\text { No sun }\end{array}$ & 20 & 1 & 5 & 19 & 95 & 0 & 0 & 5.0 & 22.3 \\
\hline $\begin{array}{l}\text { Nematode } \\
\text { Control }{ }^{2} \\
\text { No sun }\end{array}$ & 20 & 18 & 90 & 2 & 10 & 18 & 100 & 90.0 & 30.7 \\
\hline $\begin{array}{l}\text { Nematode } \\
4 \text { min sun }\end{array}$ & 20 & 16 & 80 & 4 & 20 & 16 & 100 & 80.0 & 41.0 \\
\hline $\begin{array}{l}\text { Nematode } \\
8 \text { min sun }\end{array}$ & 20 & 16 & 80 & 4 & 20 & 16 & 100 & 80.0 & 41.0 \\
\hline $\begin{array}{l}\text { Nematode } \\
16 \text { min sun }\end{array}$ & 20 & 12 & 60 & 8 & 40 & 12 & 100 & 60.0 & 50.2 \\
\hline $\begin{array}{l}\text { Nematode } \\
32 \text { min sun }\end{array}$ & 20 & 2 & 10 & 18 & 90 & 2 & 100 & 10.0 & 30.7 \\
\hline
\end{tabular}

\section{Mean consumption of cabbage}

leaves by cabbage looper

Table 14

\begin{tabular}{|c|c|c|c|c|c|c|}
\hline $\begin{array}{l}\text { Treatment } \\
\text { Exposure }\end{array}$ & $\begin{array}{l}\text { Water } \\
\text { Control }^{1}\end{array}$ & $\begin{array}{l}\text { Nematode } \\
\text { Control }^{2}\end{array}$ & $\begin{array}{l}\text { Nematode } \\
4 \mathrm{~min}\end{array}$ & $\begin{array}{l}\text { Nematode } \\
8 \mathrm{~min}\end{array}$ & $\begin{array}{l}\text { Nematode } \\
16 \mathrm{~min}\end{array}$ & $\begin{array}{l}\text { Nematode } \\
32 \mathrm{~min}\end{array}$ \\
\hline Mean & 83.75 & 65.00 & 70.00 & 68.75 & 73.75 & 86.25 \\
\hline S.D & 28.42 & 33.83 & 26.41 & 24.16 & 26.25 & 23.21 \\
\hline
\end{tabular}

Experiment \#4 (first test)

Temperature at the time of start $27^{\circ} \mathrm{C}$; Temperature at the end $31^{\circ} \mathrm{C}$ Min $=$ minutes 
Table 15

\section{Percent mortality of cabbage looper by nematodes exposed \\ to morning sunlight when the water was allowed to evaporate from the leaf surface.}

\begin{tabular}{|c|c|c|c|c|c|c|c|c|c|}
\hline $\begin{array}{l}\text { Treatment } \\
\text { Exposure }\end{array}$ & $\begin{array}{l}\# \\
\text { Larvae }\end{array}$ & $\begin{array}{l}\# \\
\text { Dead }\end{array}$ & $\begin{array}{l}\% \\
\text { Dead }\end{array}$ & $\begin{array}{l}\# \\
\text { Live }\end{array}$ & $\begin{array}{l}\% \\
\text { Live }\end{array}$ & $\begin{array}{l}\text { \# } \\
\text { Dead larvae } \\
\text { Containing } \\
\text { Nematodes }\end{array}$ & $\begin{array}{l}\% \\
\text { Dead larvae } \\
\text { Containing } \\
\text { Nematodes }\end{array}$ & Mean & S.D \\
\hline $\begin{array}{l}\text { Water } \\
\text { Control }{ }^{1} \\
\text { No sun }\end{array}$ & 30 & 0 & 0 & 30 & 100 & 0 & 0 & 0.0 & 0.0 \\
\hline $\begin{array}{l}\text { Nematode } \\
\text { Control } 2 \\
\text { No sun }\end{array}$ & 30 & 25 & 83.3 & 5 & 16.7 & 25 & 100 & 83.3 & 37.9 \\
\hline $\begin{array}{l}\text { Nematode } \\
8 \text { min sun }\end{array}$ & 30 & 22 & 73.3 & 8 & 26.7 & 22 & 100 & 73.3 & 44.9 \\
\hline $\begin{array}{l}\text { Nematode } \\
16 \text { min sun }\end{array}$ & 30 & 17 & 56.7 & 13 & 43.3 & 17 & 100 & 56.7 & 50.4 \\
\hline $\begin{array}{l}\text { Nematode } \\
32 \text { min sun }\end{array}$ & 30 & 3 & 10 & 27 & 90 & 3 & 100 & 10.0 & 30.5 \\
\hline & & & $\begin{array}{l}\text { Mean } \\
\text { leav }\end{array}$ & $\begin{array}{l}\text { consum } \\
\text { les by }\end{array}$ & $\begin{array}{l}\text { iption } \\
\text { cabba }\end{array}$ & $\begin{array}{l}\text { of cabbage } \\
\text { ge looper }\end{array}$ & & & \\
\hline Table 16 & & & & & & & & & \\
\hline $\begin{array}{l}\text { Treatment } \\
\text { Exposure }\end{array}$ & & $\begin{array}{l}\text { Water } \\
\text { Control }^{1}\end{array}$ & & $\begin{array}{l}\text { Nematode } \\
\text { Control }^{2}\end{array}$ & & $\begin{array}{l}\text { Nematode } \\
8 \mathrm{~min}\end{array}$ & $\begin{array}{l}\text { Nematode } \\
16 \mathrm{~min}\end{array}$ & $\begin{array}{l}\text { Nem } \\
32 n\end{array}$ & $\begin{array}{l}\text { atode } \\
\text { in }\end{array}$ \\
\hline Mean & & 85.83 & & 67.50 & & 70.83 & 80.83 & 81.6 & \\
\hline S.D & & 21.46 & & 25.55 & & 24.64 & 23.38 & 24.5 & \\
\hline
\end{tabular}




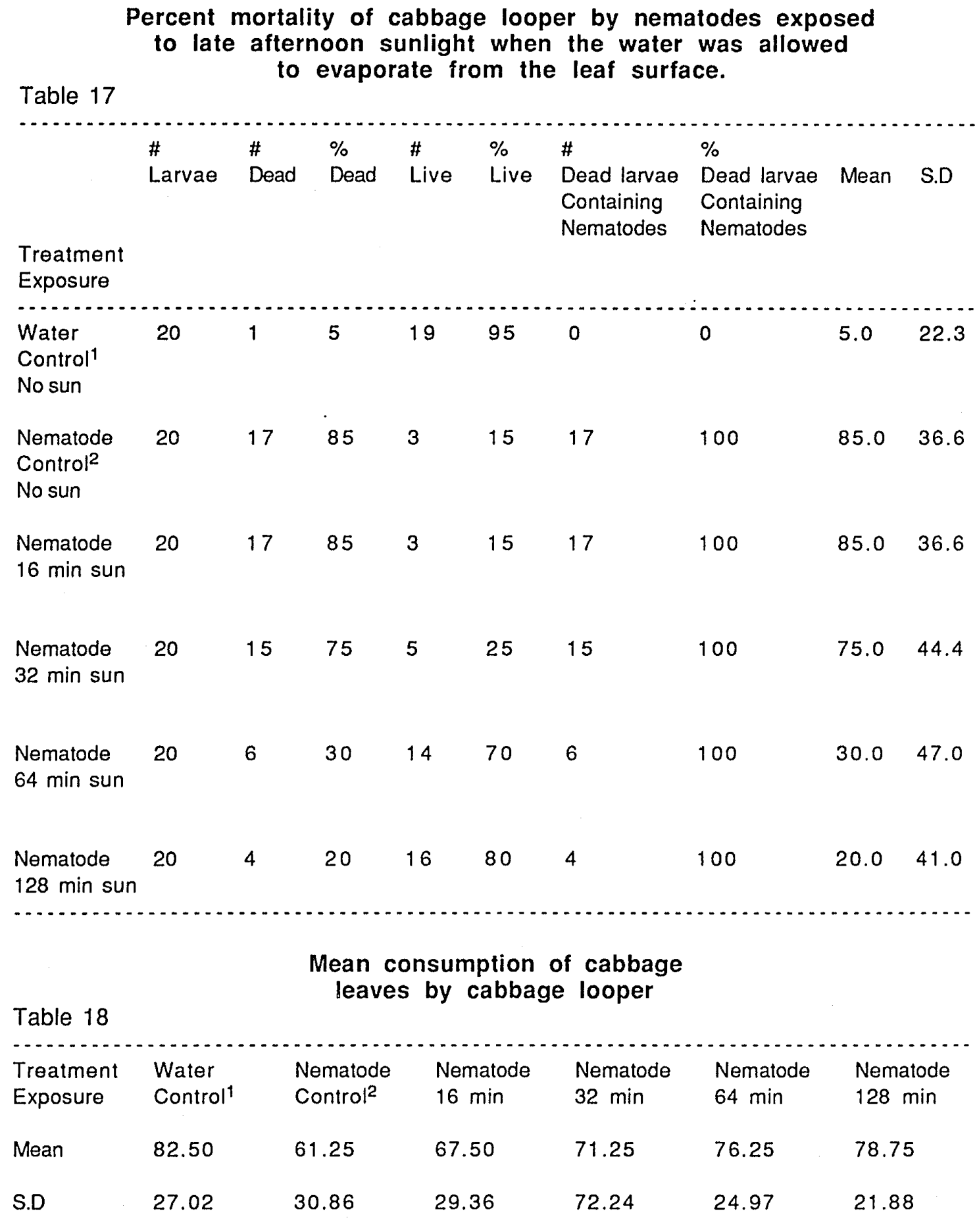

Experiment \#5 (first test)

Temperature at the time of start $25^{\circ} \mathrm{C}$; Temperature at the end $16^{\circ} \mathrm{C}$ Min $=$ minutes 
Table 19

\section{Percent mortality of cabbage looper by nematodes exposed to late afternoon sunlight when the water was allowed to evaporate from the leaf surface.}

\begin{tabular}{|c|c|c|c|c|c|c|c|c|c|}
\hline $\begin{array}{l}\text { Treatment } \\
\text { Exposure }\end{array}$ & $\begin{array}{l}\# \\
\text { Larvae }\end{array}$ & $\begin{array}{l}\# \\
\text { Dead }\end{array}$ & $\begin{array}{l}\% \\
\text { Dead }\end{array}$ & $\begin{array}{l}\# \\
\text { Live }\end{array}$ & $\begin{array}{l}\% \\
\text { Live }\end{array}$ & $\begin{array}{l}\# \\
\text { Dead larvae } \\
\text { Containing } \\
\text { Nematodes }\end{array}$ & $\begin{array}{l}\% \\
\text { Dead larvae } \\
\text { Containing } \\
\text { Nematodes }\end{array}$ & Mean & S.D \\
\hline $\begin{array}{l}\text { Water } \\
\text { Control }^{1} \\
\text { No sun }\end{array}$ & 30 & 0 & 0 & 30 & 100 & 0 & 0 & 0.0 & 0.0 \\
\hline $\begin{array}{l}\text { Nematode } \\
\text { Control }{ }^{2} \\
\text { No sun }\end{array}$ & 30 & 28 & 93.3 & 2 & 6.7 & 28 & 100 & 93.3 & 25.3 \\
\hline $\begin{array}{l}\text { Nematode } \\
16 \text { min sun }\end{array}$ & 30 & 27 & 90 & 3 & 10 & 27 & 100 & 90.0 & 30.5 \\
\hline $\begin{array}{l}\text { Nematode } \\
32 \text { min }\end{array}$ & 30 & 24 & 80 & 6 & 20 & 24 & 100 & 80.0 & 40.6 \\
\hline $\begin{array}{l}\text { Nematode } \\
64 \text { min sun }\end{array}$ & 30 & 11 & 36.7 & 19 & 63.3 & 11 & 100 & 36.7 & 49.0 \\
\hline $\begin{array}{l}\text { Nematode } \\
128 \text { min sun }\end{array}$ & 30 & 7 & 23.3 & 23 & 76.7 & 7 & 100 & 23.3 & 43.0 \\
\hline \multicolumn{10}{|c|}{$\begin{array}{l}\text { Mean consumption of cabbage } \\
\text { leaves by cabbage looper }\end{array}$} \\
\hline $\begin{array}{l}\text { Treatment } \\
\text { Exposure }\end{array}$ & $\begin{array}{l}\text { Water } \\
\text { Control }^{1}\end{array}$ & & $\begin{array}{l}\text { Nematode } \\
\text { Control }{ }^{2}\end{array}$ & & $\begin{array}{l}\text { natode } \\
\min \end{array}$ & $\begin{array}{l}\text { Nematode } \\
32 \mathrm{~min}\end{array}$ & $\begin{array}{l}\text { Nematode } \\
64 \text { min }\end{array}$ & $\begin{array}{l}\text { Nema } \\
128\end{array}$ & atode \\
\hline Mean & 85.83 & & 62.93 & & & 74.17 & 82.50 & 85.0 & \\
\hline S.D & 29.86 & & 22.78 & 23 & & 27.45 & 25.55 & 25.09 & \\
\hline
\end{tabular}

Experiment \#5 (confirmation test)

Temperature at the time of start $24^{\circ} \mathrm{C}$; Temperature at the end $17^{\circ} \mathrm{C}$

Min $=$ minutes 
Table 21

\section{Mortality of black cutworm, 96 hours after treated with nematodes, when nematodes were kept indoors under the controlled conditions.}

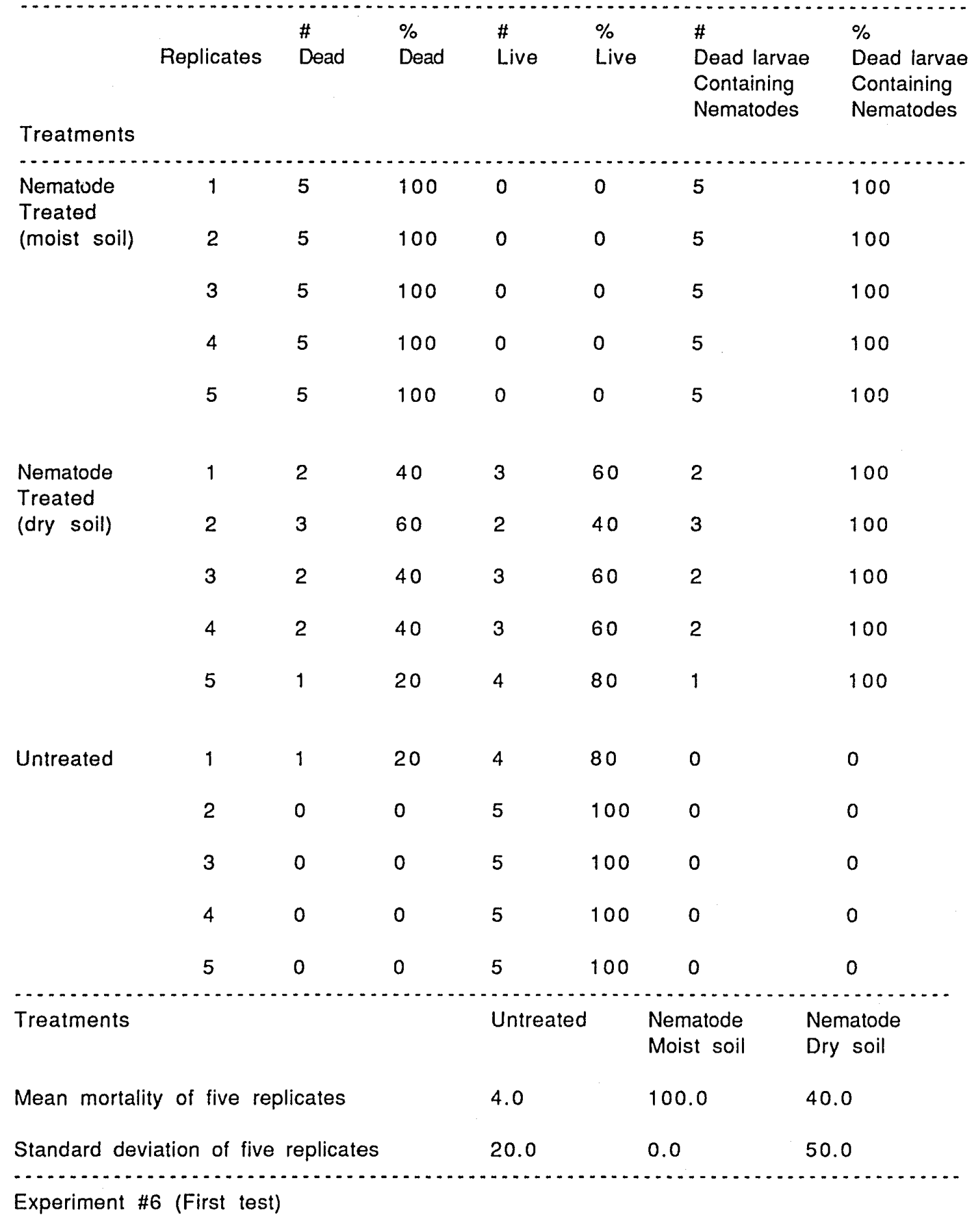


Table 22

Mortality of black cutworm, 96 hours after treated

with nematodes, when nematodes were kept indoors under the controlled conditions.

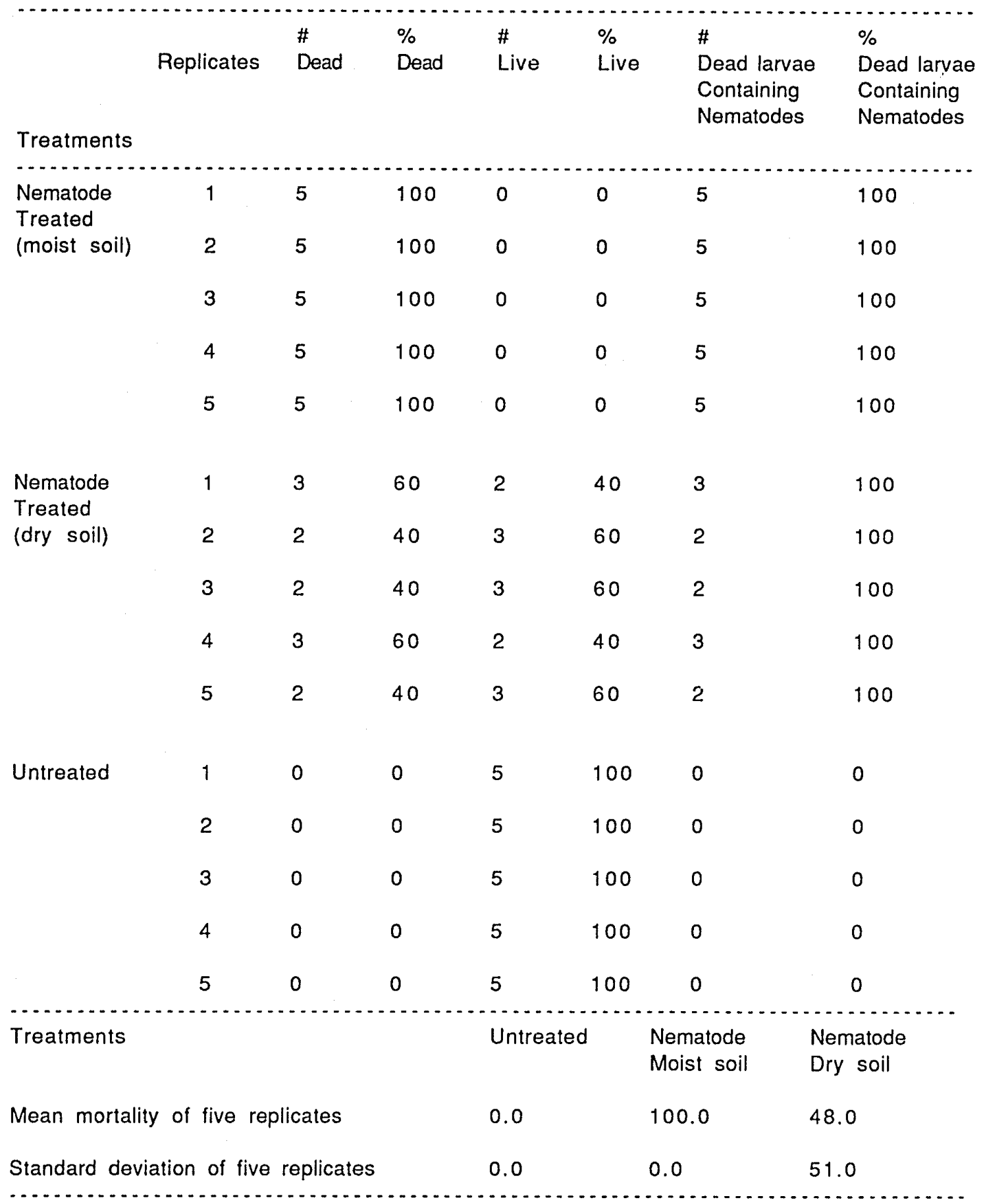

Experiment \#6 (confirmation test) 


\section{Percent cutworm damage to cabbage plants, 96 hours after treated with nematodes, when nematodes were kept indoors under the controlled conditions.}

\section{Table 23}

Treatments

Soil conditions at the time of application

$\begin{array}{lll}\text { Untreated } & \text { Nematode } & \text { Nematode } \\ \text { Moist } & \text { Moist } & \text { Dry }\end{array}$

Replicates Flat information

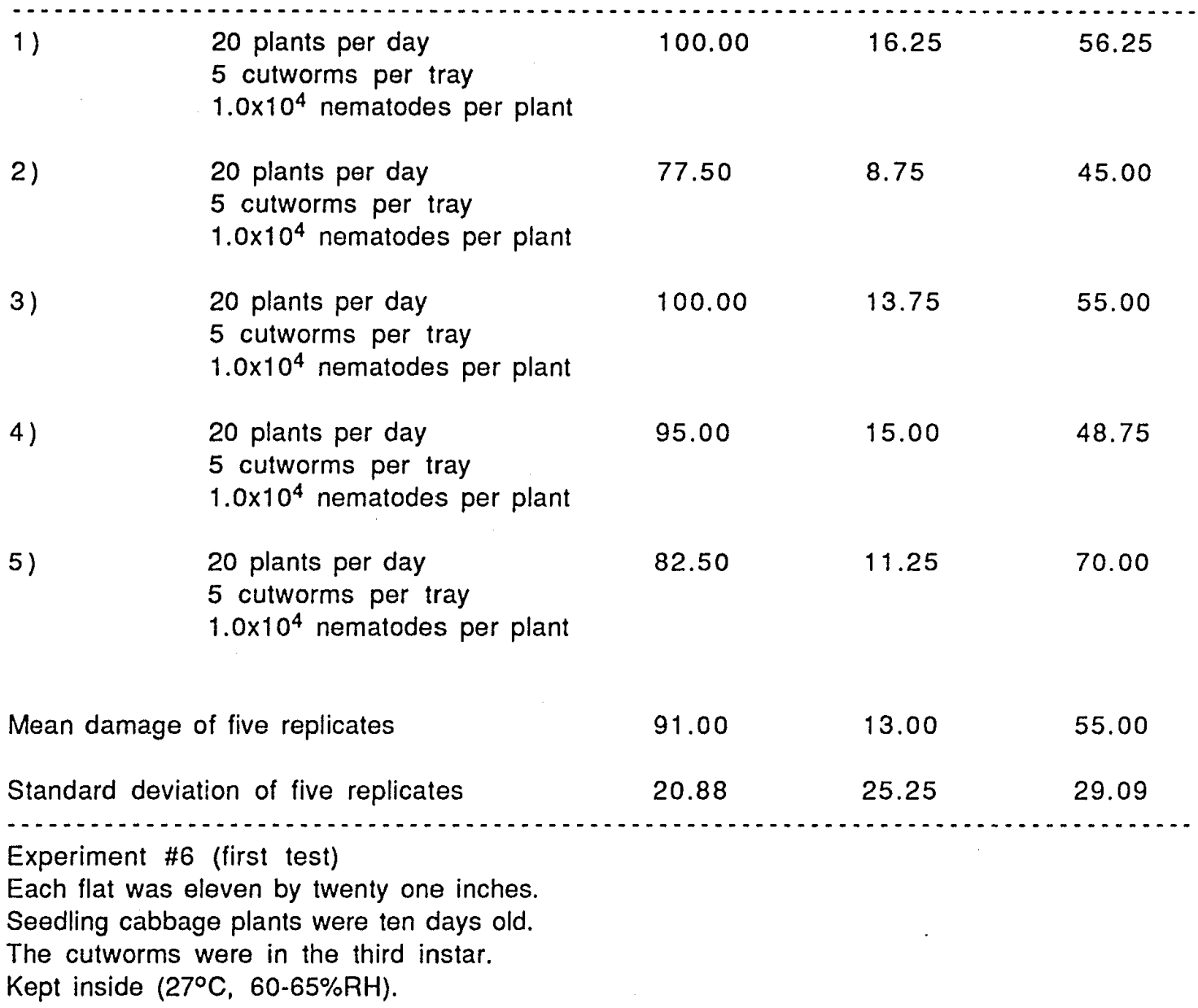




\section{Percent cutworm damage to cabbage plants, 96 hours after treated with nematodes, when nematodes were kept indoors under the controlled conditions.}

Table 24

Treatments

$\begin{array}{lll}\text { Untreated } & \text { Nematode } & \text { Nematode } \\ \text { Moist } & \text { Moist } & \text { Dry }\end{array}$

Soil conditions at the time of application

Moist

Moist

Dry

Replicates Flat information

1)

1)

20 plants per day

77.50

15.00

43.75

5 cutworms per tray

$1.0 \times 10^{4}$ nematodes per plant

2)

20 plants per day

100.00

13.75

52.50

5 cutworms per tray

$1.0 \times 10^{4}$ nematodes per plant

3)

20 plants per day

100.00

11.25

56.25

5 cutworms per tray

$1.0 \times 10^{4}$ nematodes per plant

4)

20 plants per day

76.25

12.50

50.00

5 cutworms per tray

$1.0 \times 10^{4}$ nematodes per plant

5)
20 plants per day
5 cutworms per tray
$1.0 \times 10^{4}$ nematodes per plant

83.75

10.00

53.75

Mean damage of five replicates

87.50

12.50

51.25

Standard deviation of five replicates

23.97

22.33

28.95

Experiment \#6 (confirmation test)

Each flat was eleven by twenty one inches.

Seedling cabbage plants were ten days old.

The cutworms were in the third instar.

Kept inside $\left(27^{\circ} \mathrm{C}, 60-65 \% \mathrm{RH}\right)$. 
Table 25

\section{Mortality of black cutworm, 96 hours after treated} with nematodes (morning applications).

\begin{tabular}{|c|c|c|c|c|c|c|c|}
\hline & Replicates & $\begin{array}{l}\# \\
\text { Dead }\end{array}$ & $\begin{array}{l}\% \\
\text { Dead }\end{array}$ & $\begin{array}{l}\# \\
\text { Live }\end{array}$ & $\begin{array}{l}\% \\
\text { Live }\end{array}$ & $\begin{array}{l}\# \\
\text { Dead larvae } \\
\text { Containing } \\
\text { Nematodes }\end{array}$ & $\begin{array}{l}\% \\
\text { Dead larvae } \\
\text { Containing } \\
\text { Nematodes }\end{array}$ \\
\hline \multicolumn{8}{|l|}{ Treatments } \\
\hline \multirow{5}{*}{$\begin{array}{l}\text { Nematode } \\
\text { Treated } \\
\text { (moist soil }\end{array}$} & 1 & 2 & 40 & 3 & 60 & 2 & 100 \\
\hline & 2 & 1 & 20 & 4 & 80 & 1 & 100 \\
\hline & 3 & 0 & 0 & 5 & 100 & 0 & 0 \\
\hline & 4 & 0 & 0 & 5 & 100 & 0 & 0 \\
\hline & 5 & 2 & 40 & 3 & 60 & 2 & 100 \\
\hline \multirow[t]{5}{*}{ Untreated } & 1 & 0 & 0 & 5 & 100 & 0 & 0 \\
\hline & 2 & 0 & 0 & 5 & 100 & 0 & 0 \\
\hline & 3 & 0 & 0 & 5 & 100 & 0 & 0 \\
\hline & 4 & 0 & 0 & 5 & 100 & 0 & 0 \\
\hline & 5 & 0 & 0 & 5 & 100 & 0 & 0 \\
\hline \multicolumn{4}{|c|}{ Mean mortality of five replicates } & \multicolumn{2}{|c|}{$\begin{array}{l}\text { Untreated } \\
0.0\end{array}$} & \multicolumn{2}{|c|}{$\begin{array}{l}\text { Nematode } \\
20.0\end{array}$} \\
\hline \multicolumn{4}{|c|}{ Standard deviation of five replicates } & 0.0 & & \multicolumn{2}{|c|}{40.8} \\
\hline
\end{tabular}

Experiment \#7 (first test) 
Table 26

\section{Mortality of black cutworm, 96 hours after treated with nematodes (morning applications).}

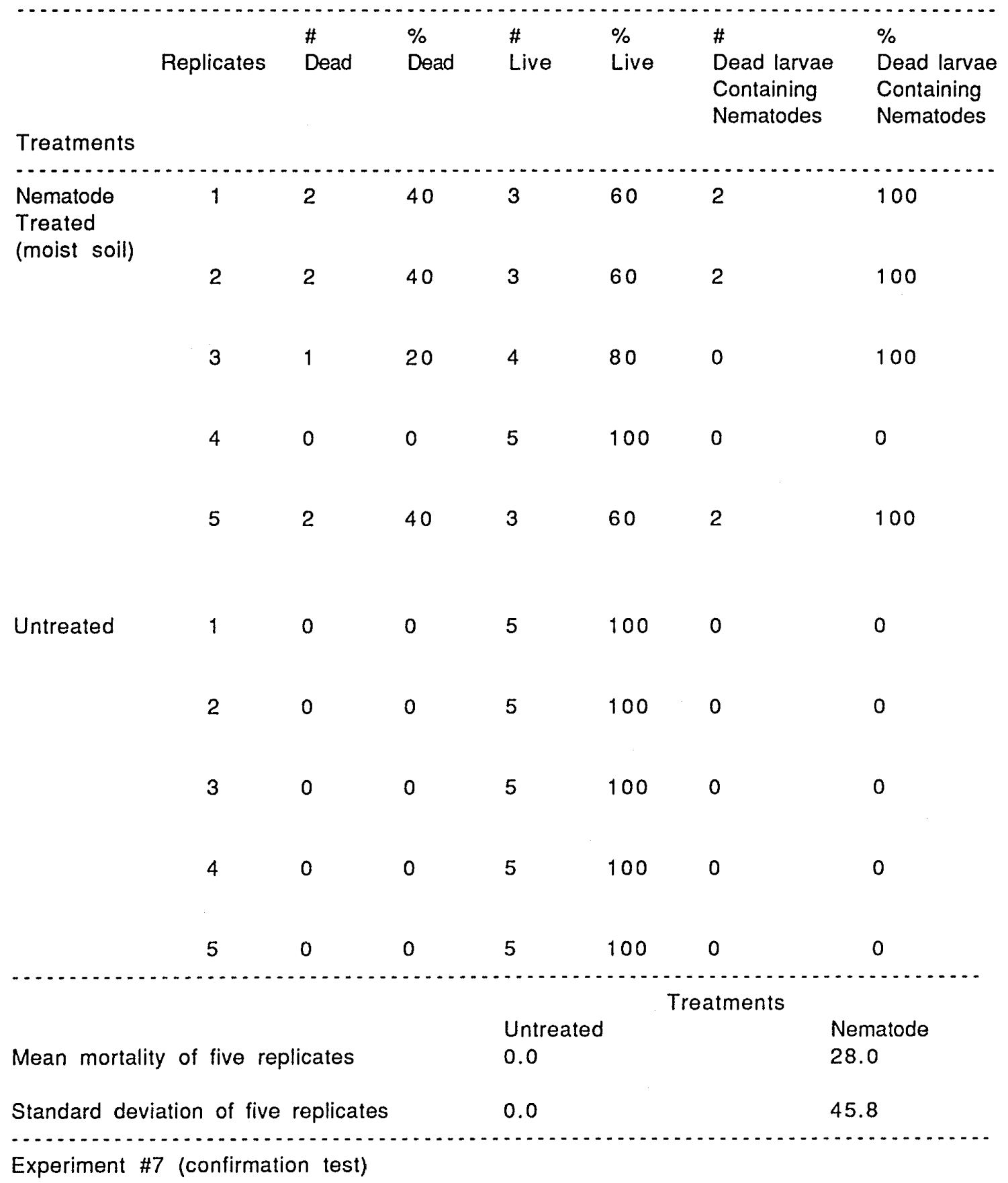




\section{Percent cutworm damage to cabbage plants, 96 hours after treated with nematodes (morning applications).}

Table 27

Treatments

$\begin{array}{lll}\text { Soil conditions at the time of application } & \text { Untreated } & \text { Nematode } \\ \text { Moist } & \text { Moist }\end{array}$

Replicates Flat information

\begin{tabular}{|c|c|c|c|}
\hline 1) & $\begin{array}{l}20 \text { plants per day } \\
5 \text { cutworms per tray } \\
1.0 \times 10^{4} \text { nematodes per plant }\end{array}$ & 80.00 & 51.25 \\
\hline 2) & $\begin{array}{l}20 \text { plants per day } \\
5 \text { cutworms per tray } \\
1.0 \times 10^{4} \text { nematodes per plant }\end{array}$ & 71.25 & 61.25 \\
\hline 3) & $\begin{array}{l}20 \text { plants per day } \\
5 \text { cutworms per tray } \\
1.0 \times 10^{4} \text { nematodes per plant }\end{array}$ & 81.25 & 70.00 \\
\hline 4) & $\begin{array}{l}20 \text { plants per day } \\
5 \text { cutworms per tray } \\
1.0 \times 10^{4} \text { nematodes per plant }\end{array}$ & 82.50 & 85.00 \\
\hline 5) & $\begin{array}{l}20 \text { plants per day } \\
5 \text { cutworms per tray } \\
1.0 \times 10^{4} \text { nematodes per plant }\end{array}$ & 78.75 & 58.75 \\
\hline
\end{tabular}

Mean damage of five replicates

78.75

65.25

Standard deviation of five replicates

28.73

29.92

Experiment \#7 (first test)

Each flat was eleven by twenty one inches.

Seedling cabbage plants were ten days old.

The cutworms were in the third instar.

Mean temperature was $14.5^{\circ} \mathrm{C}$. 


\section{Percent cutworm damage to cabbage plants, 96 hours after treated with nematodes (morning applications).}

\section{Table 28}

Treatments

$\begin{array}{lll} & \text { Untreated } & \text { Nematode } \\ \text { Soil conditions at the time of application } & \text { Moist } & \text { Moist }\end{array}$

Replicates Flat information

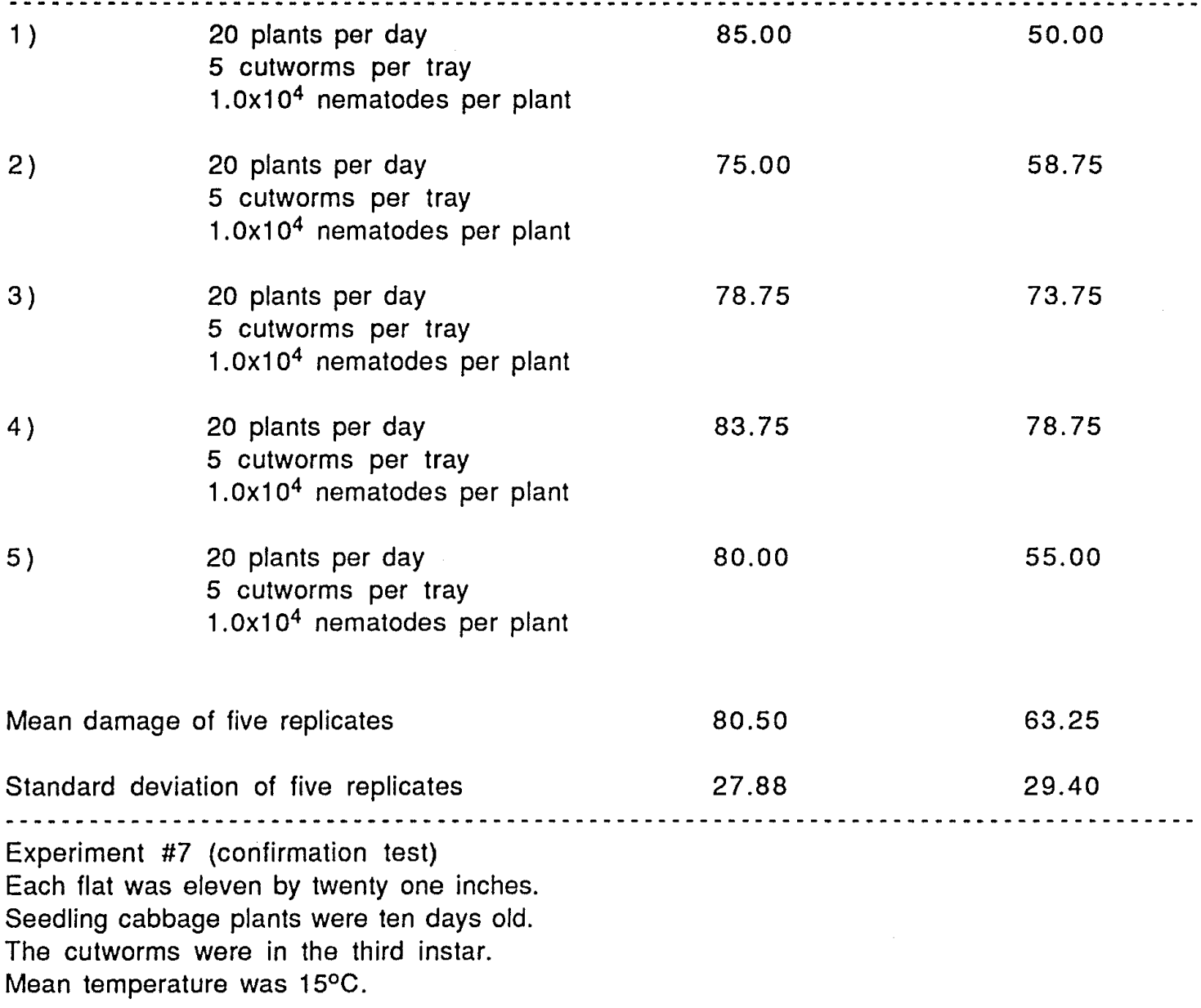




\section{Table 29}

Moriality of black cutworm, 96 hours after treated with nematodes (late afternoon applications).

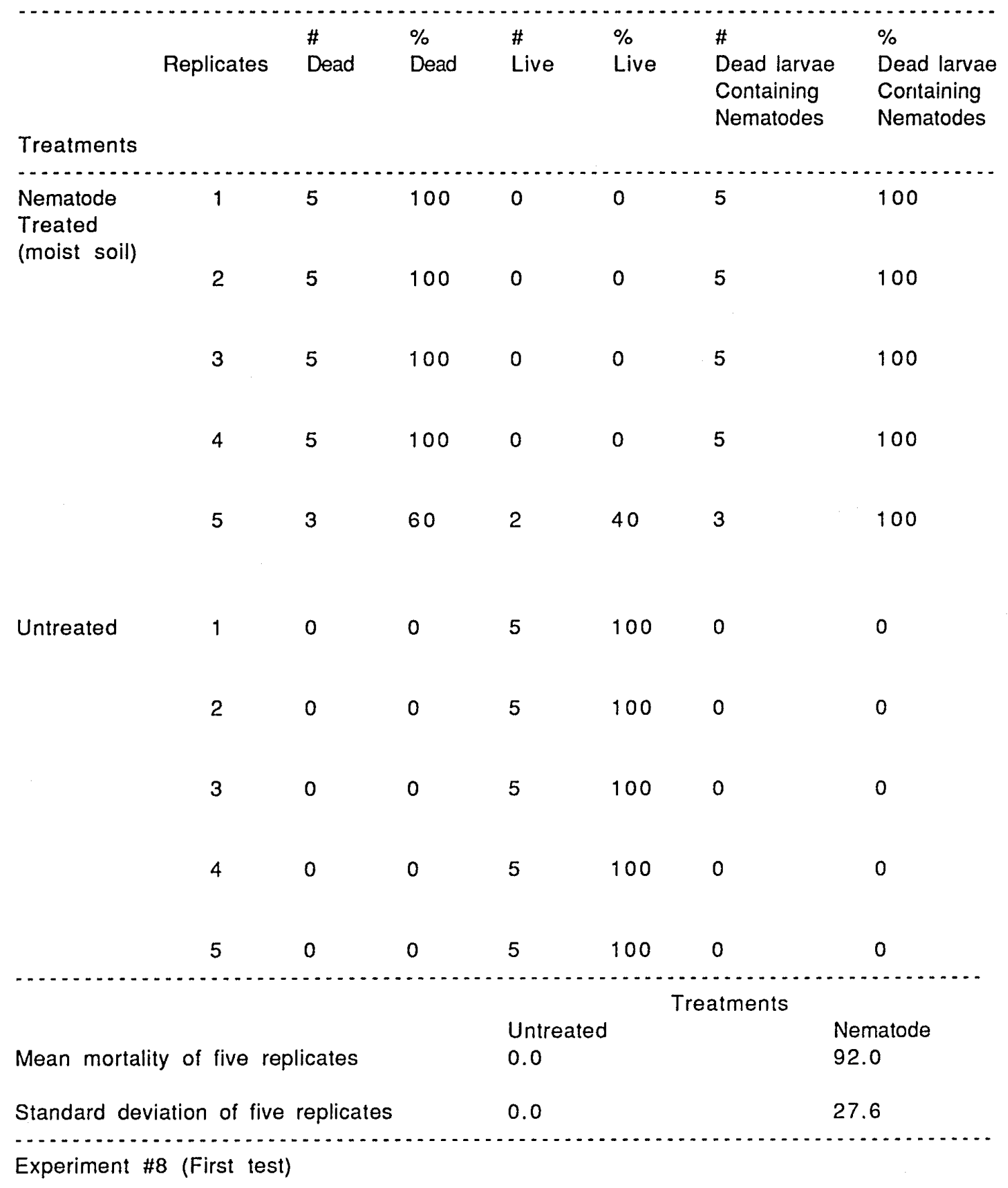




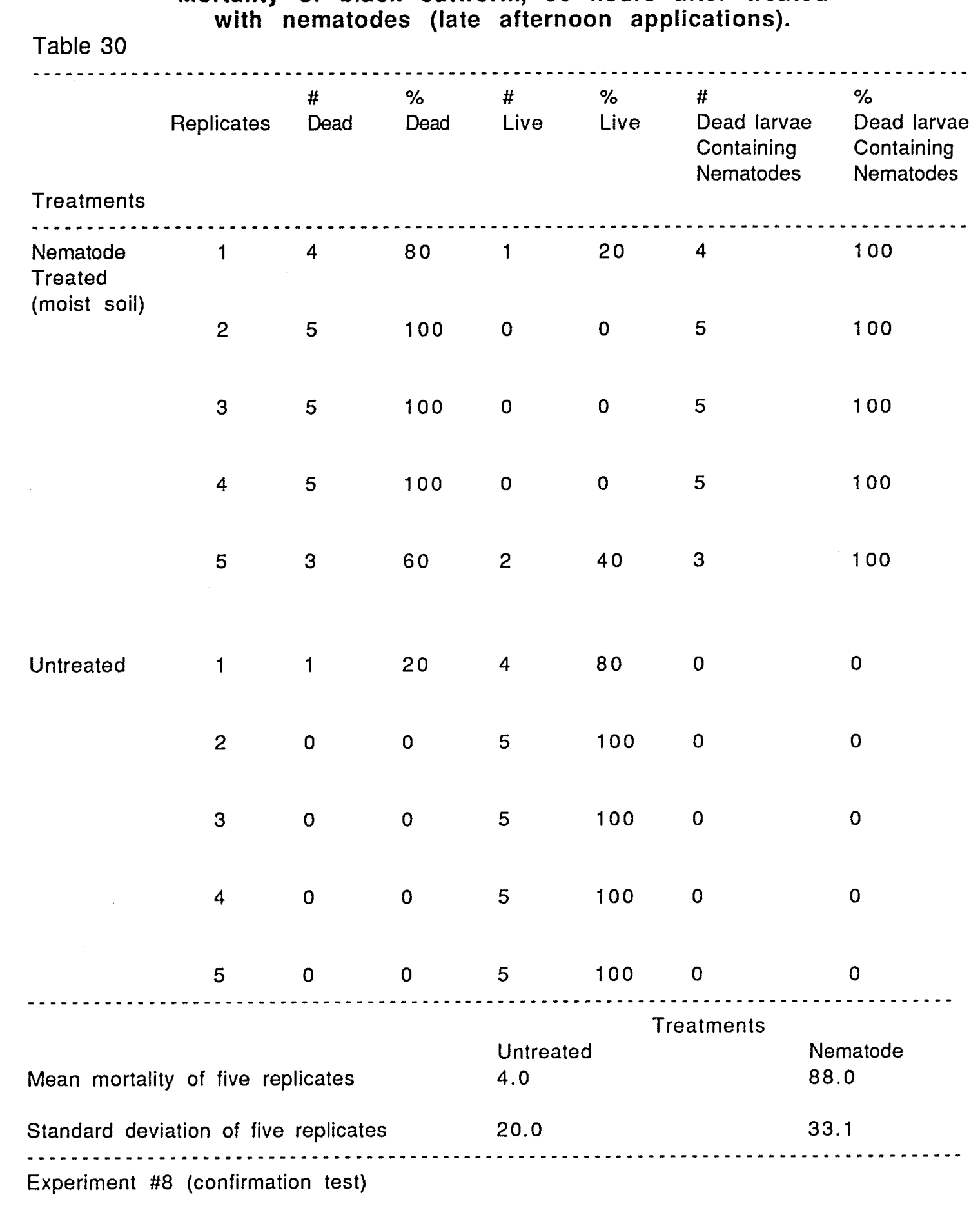

Mortality of black cutworm, 96 hours after treated with nematodes (late afternoon applications). 


\section{Percent cutworm damage to cabbage plants, 96 hours after treated with nematodes (late afternoon applications).}

\section{Table 31}

\begin{tabular}{|c|c|c|c|}
\hline \multirow{2}{*}{\multicolumn{2}{|c|}{ Soil conditions at the time of application }} & \multicolumn{2}{|c|}{ Treatments } \\
\hline & & \multirow[t]{2}{*}{$\begin{array}{l}\text { Untreated } \\
\text { Moist }\end{array}$} & \multirow[t]{2}{*}{$\begin{array}{l}\text { Nematode } \\
\text { Moist }\end{array}$} \\
\hline Replicates & Flat information & & \\
\hline \multicolumn{2}{|c|}{$\begin{array}{l}20 \text { plants per day } \\
5 \text { cutworms per tray } \\
1.0 \times 10^{4} \text { nematodes per plant }\end{array}$} & 88.75 & 18.75 \\
\hline 2) & $\begin{array}{l}20 \text { plants per day } \\
5 \text { cutworms per tray } \\
1.0 \times 10^{4} \text { nematodes per plant }\end{array}$ & 93.75 & 11.25 \\
\hline 3) & $\begin{array}{l}20 \text { plants per day } \\
5 \text { cutworms per tray } \\
1.0 \times 10^{4} \text { nematodes per plant }\end{array}$ & 85.00 & 18.75 \\
\hline 4) & $\begin{array}{l}20 \text { plants per day } \\
5 \text { cutworms per tray } \\
1.0 \times 10^{4} \text { nematodes per plant }\end{array}$ & 82.50 & 16.25 \\
\hline 5) & $\begin{array}{l}20 \text { plants per day } \\
5 \text { cutworms per tray } \\
1.0 \times 10^{4} \text { nematodes per plant }\end{array}$ & 77.50 & 20.00 \\
\hline \multicolumn{2}{|c|}{ Mean damage of five replicates } & 85.50 & 17.00 \\
\hline \multirow{2}{*}{\multicolumn{2}{|c|}{$\begin{array}{l}\text { Standard deviation of five replicates } \\
\text { Experiment } \# 8 \text { (first test) } \\
\text { Seedling cabbage plants were ten days old. } \\
\text { The cutworms were in the third instar. } \\
\text { Mean temperature was } 15^{\circ} \mathrm{C} \text {. }\end{array}$}} & 23.88 & 26.56 \\
\hline & & & \\
\hline
\end{tabular}




\section{Percent cutworm damage to cabbage plants, 96 hours after treated with nematodes (late afternoon applications).}

Table 32

Treatments

Soil conditions at the time of application

Untreated

Nematode

Moist

Moist

Replicates Flat information

1)

20 plants per day

72.50

21.25

5 cutworms per tray

$1.0 \times 10^{4}$ nematodes per plant

2)

20 plants per day

85.00

12.50

5 cutworms per tray

$1.0 \times 10^{4}$ nematodes per plant

3)

20 plants per day

78.75

18.75

5 cutworms per tray

$1.0 \times 10^{4}$ nematodes per plant

4)

20 plants per day

80.00

20.00

5 cutworms per tray

$1.0 \times 10^{4}$ nematodes per plant

5)

20 plants per day

91.25

18.75

5 cutworms per tray

$1.0 \times 10^{4}$ nematodes per plant

Mean damage of five replicates

81.50

18.25

Standard deviation of five replicates

27.44

27.26

Experiment \#8 (confirmation test)

Each flat was eleven by twenty one inches.

Seedling cabbage plants were ten days old.

The cutworms were in the third instar.

Mean temperature was $16^{\circ} \mathrm{C}$. 
Fig.1 Percent mortality of cabbage looper by nematodes when the diluent (water) was allowed to evaporate from the leaf surface (first test).

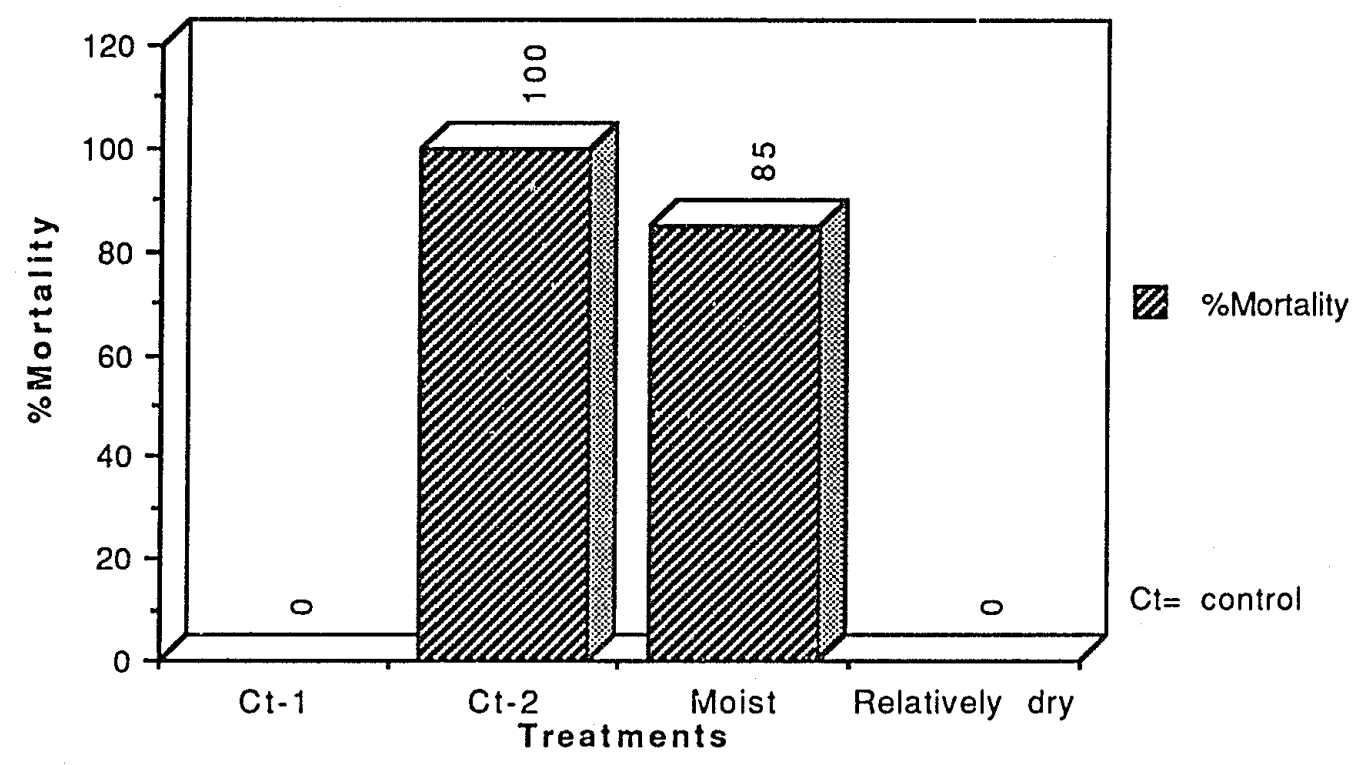

Fig.2 Percent mortality of cabbage looper by nematodes when the diluent (water) was allowed to evaporate from the leaf surface (confirmation test).

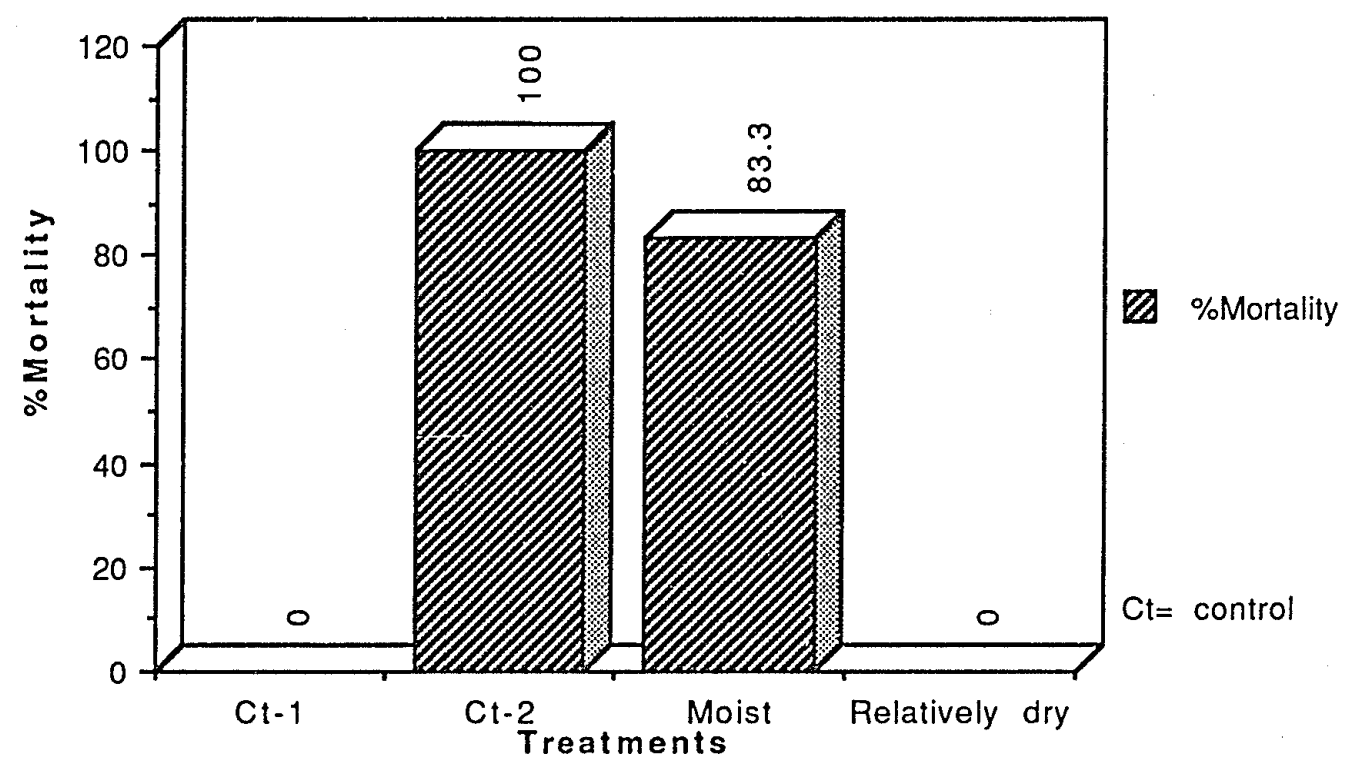


Fig.3 Percent mortality of cabbage looper by nematodes exposed to morning sunlight (first test).

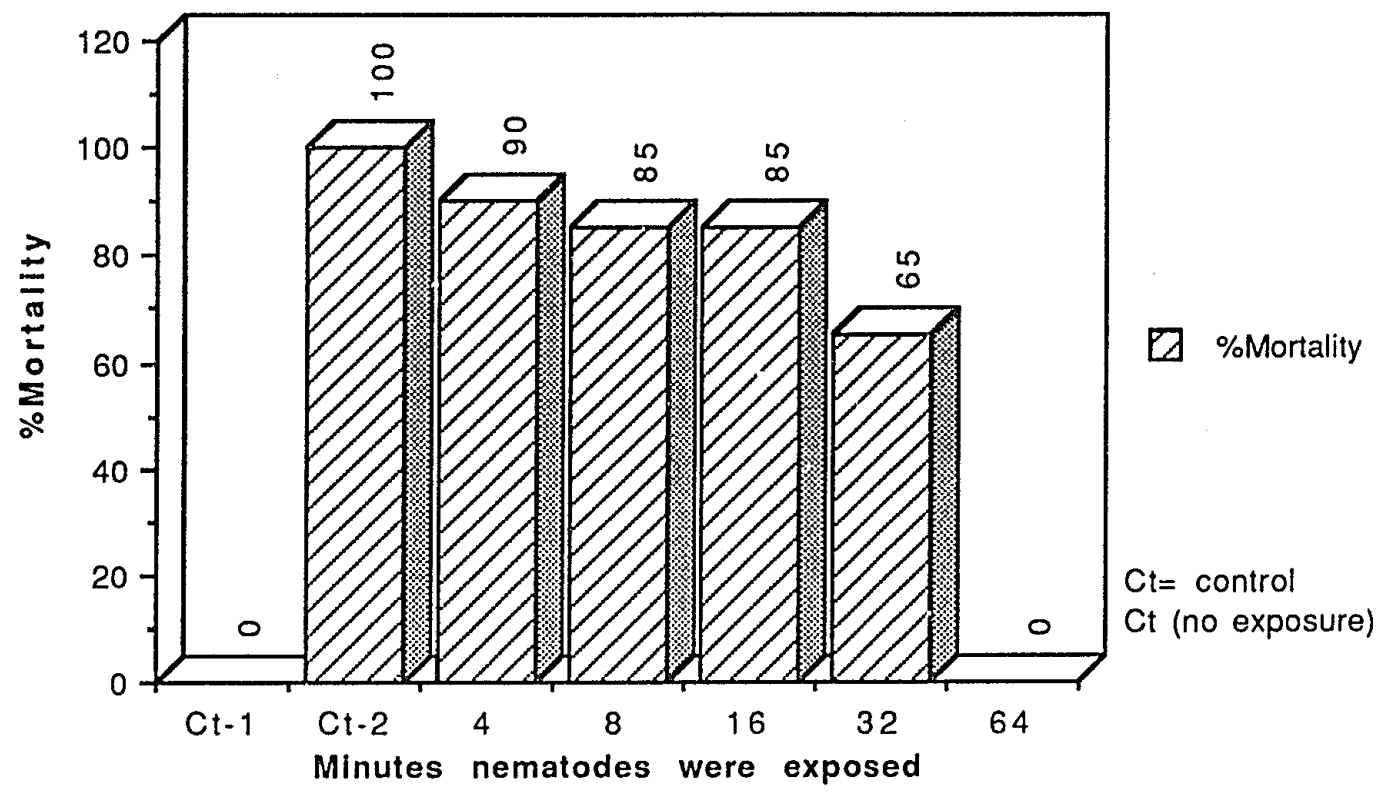

Fig.4 Percent mortality of cabbage looper by nematodes exposed to morning sunlight (confirmation test).

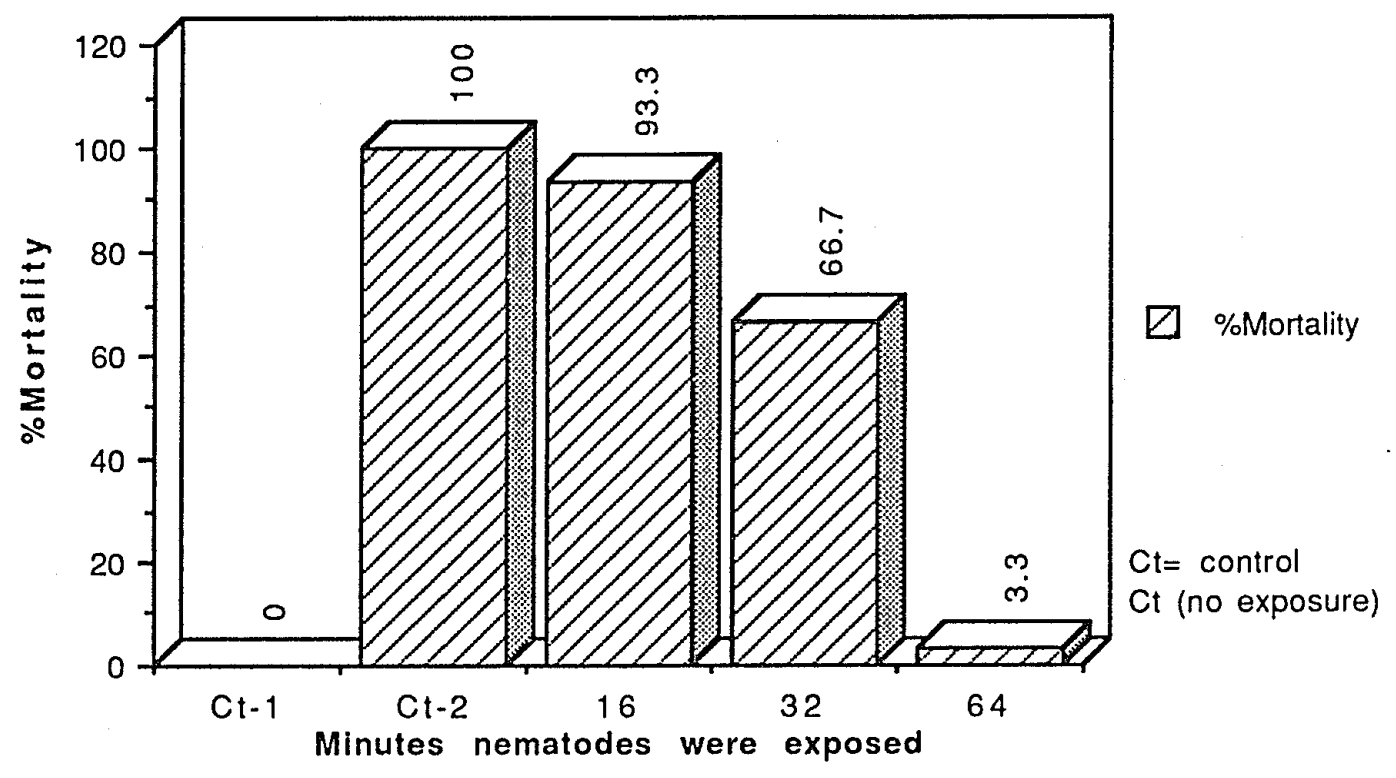


Fig.5 Percent mortality of cabbage looer by nematodes exposed to late afternoon sunlight (first test).

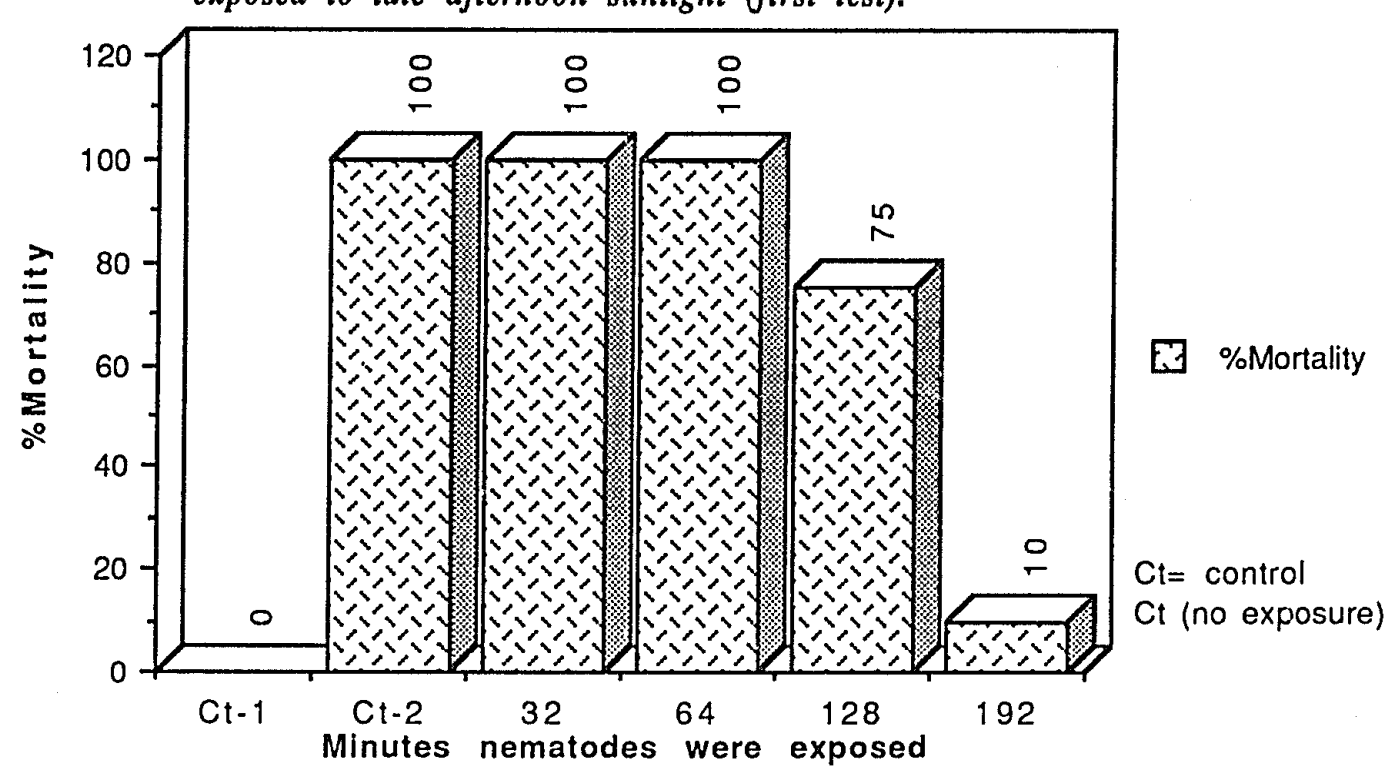

Fig.6 Percent mortality of cabbage looper by nematodes exposed to late afternoon sunlight (confirmation test).

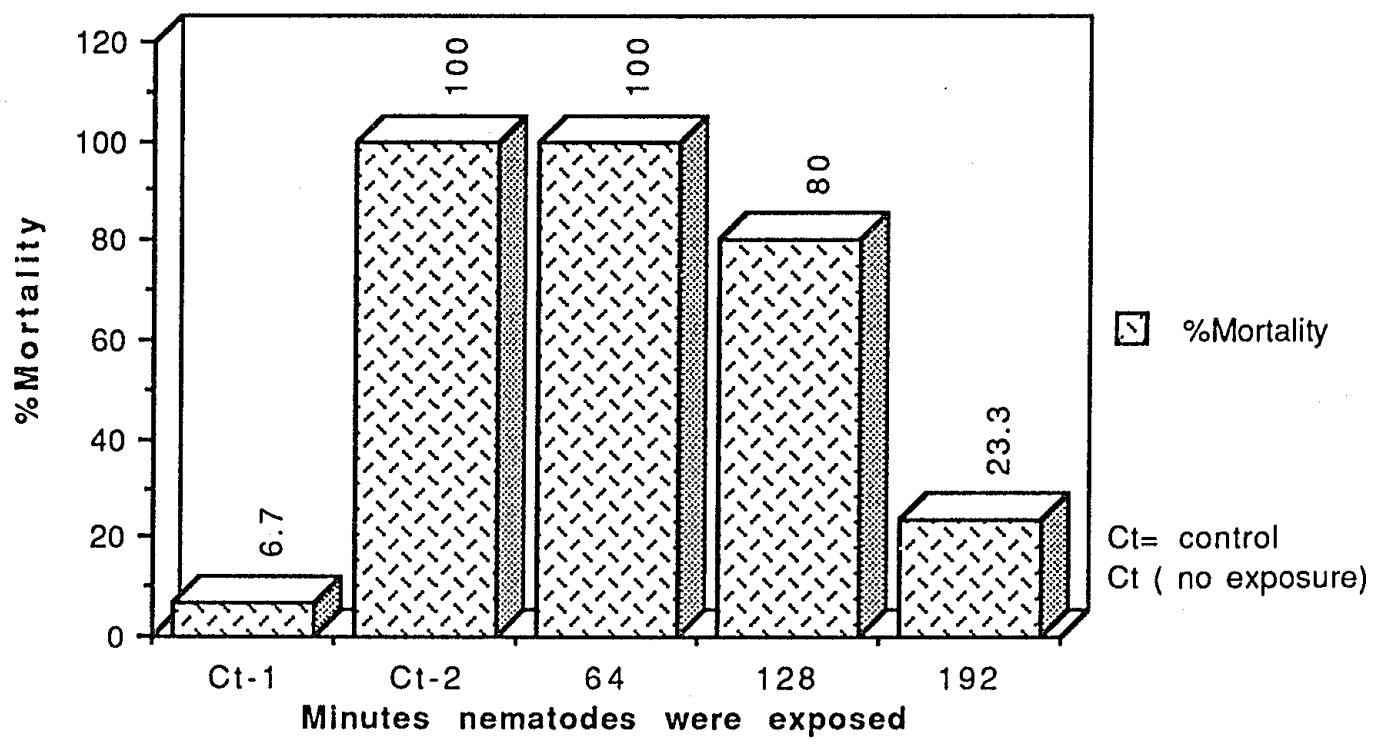


fig.7 Percent mortality of cabbage looper by nematodes exposed to morning sunlight when the water was allowed to evaporate from the leaf surface (first test).

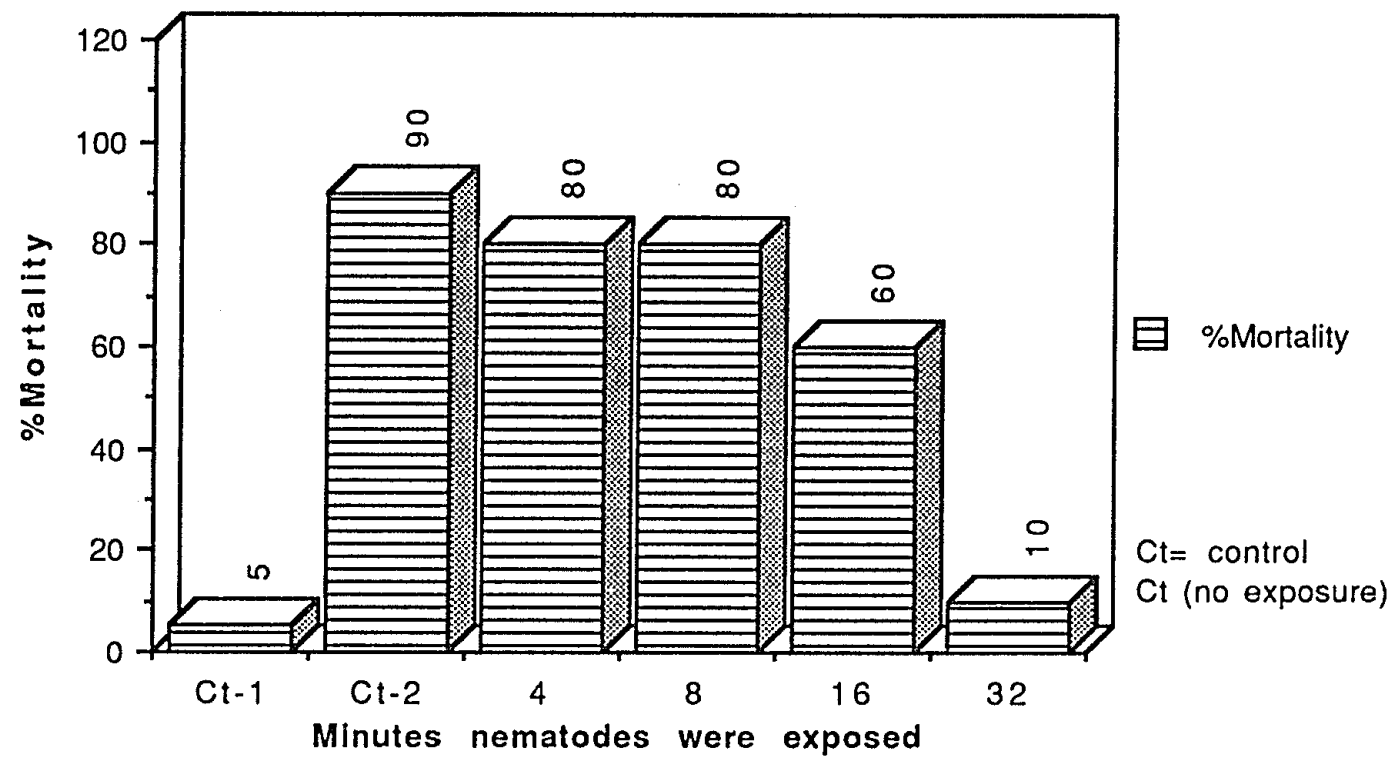

Fig.8 Percent mortality of cabbage looper by nematodes exposed to morning sunlight when the water was allowed to evaporate from the leaf surface (confirmation test).

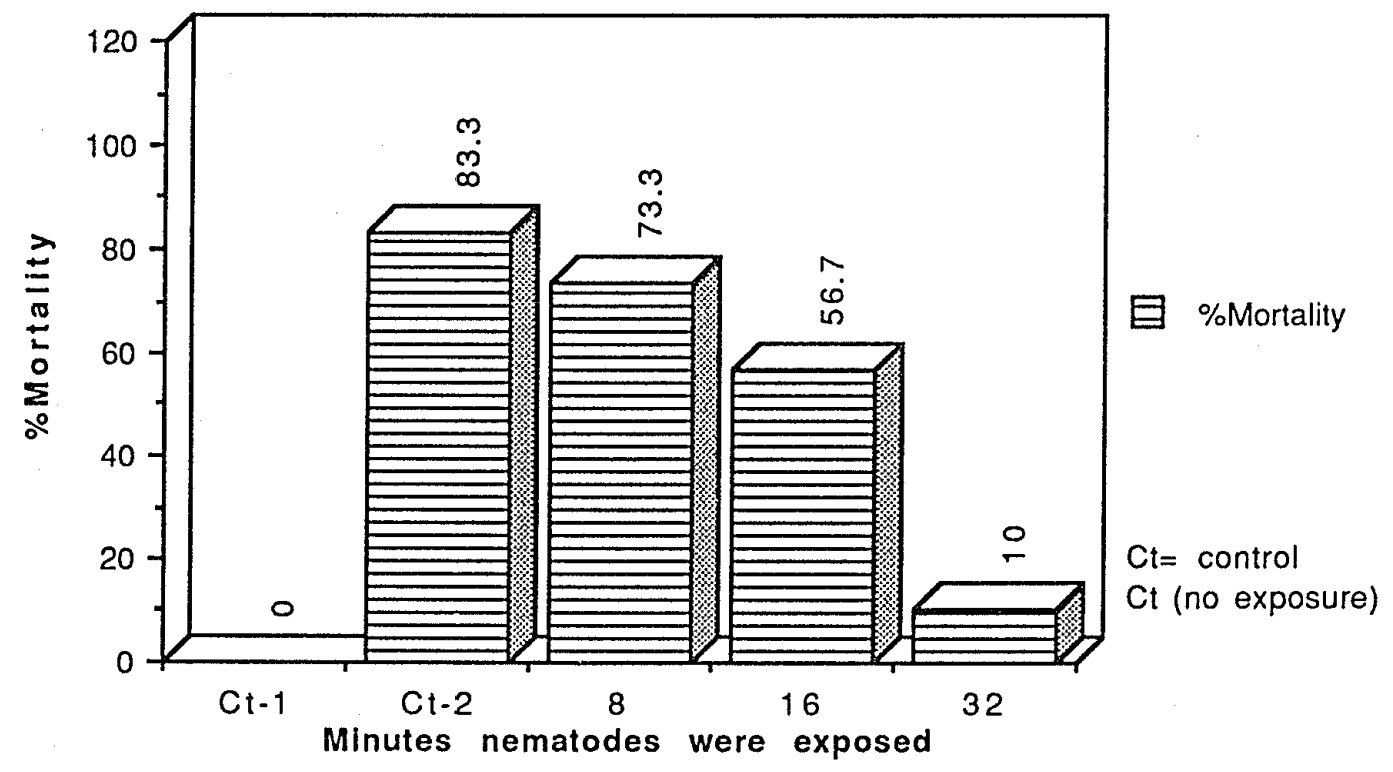


Fig.9 Percent mortality of cabbage looper by nematodes exposed to late afternoon sunlight when the water was allowed to evaporate from the leaf surface (first test).

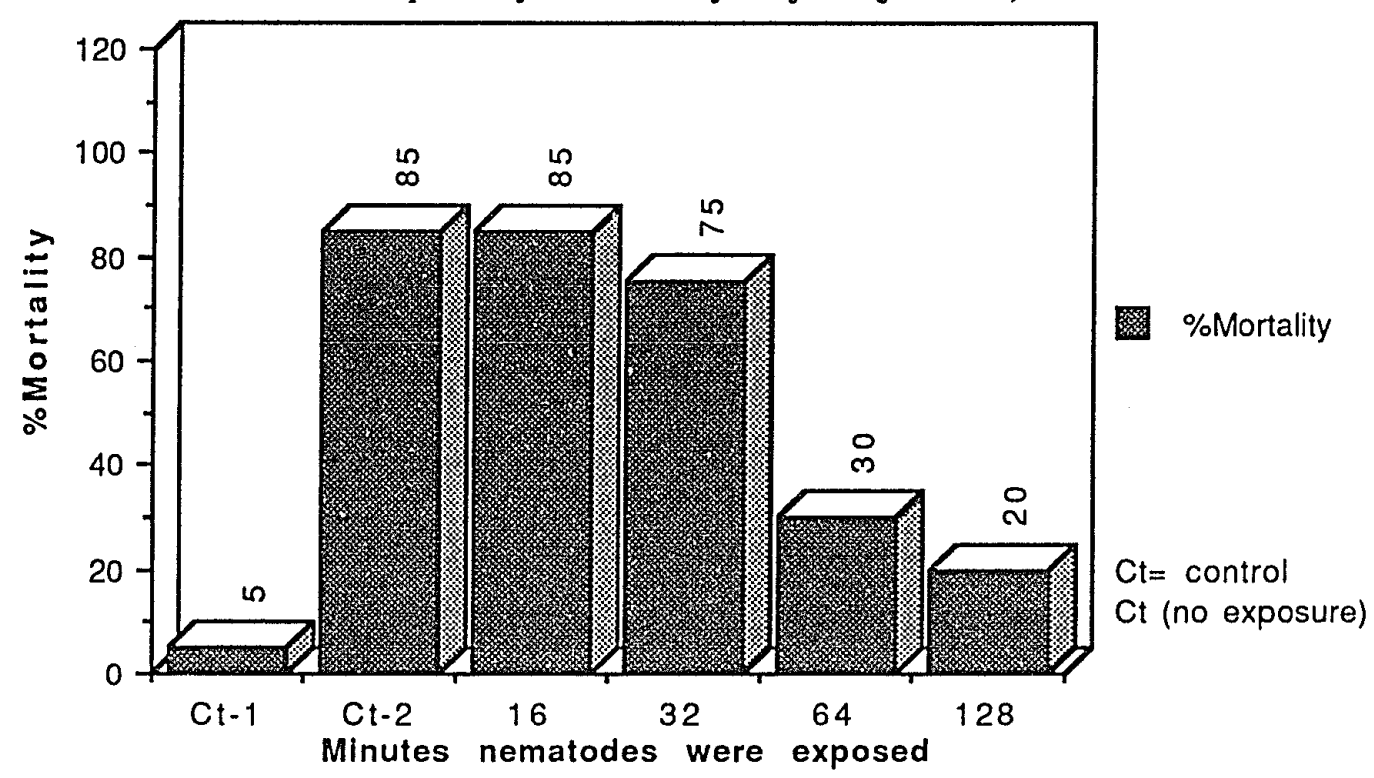

Fig.10 Percent mortality of cabbage looper by nematodes exposed to late afternoon sunlight when the water was allowed to evaporate from the leaf surface (confirmation test).

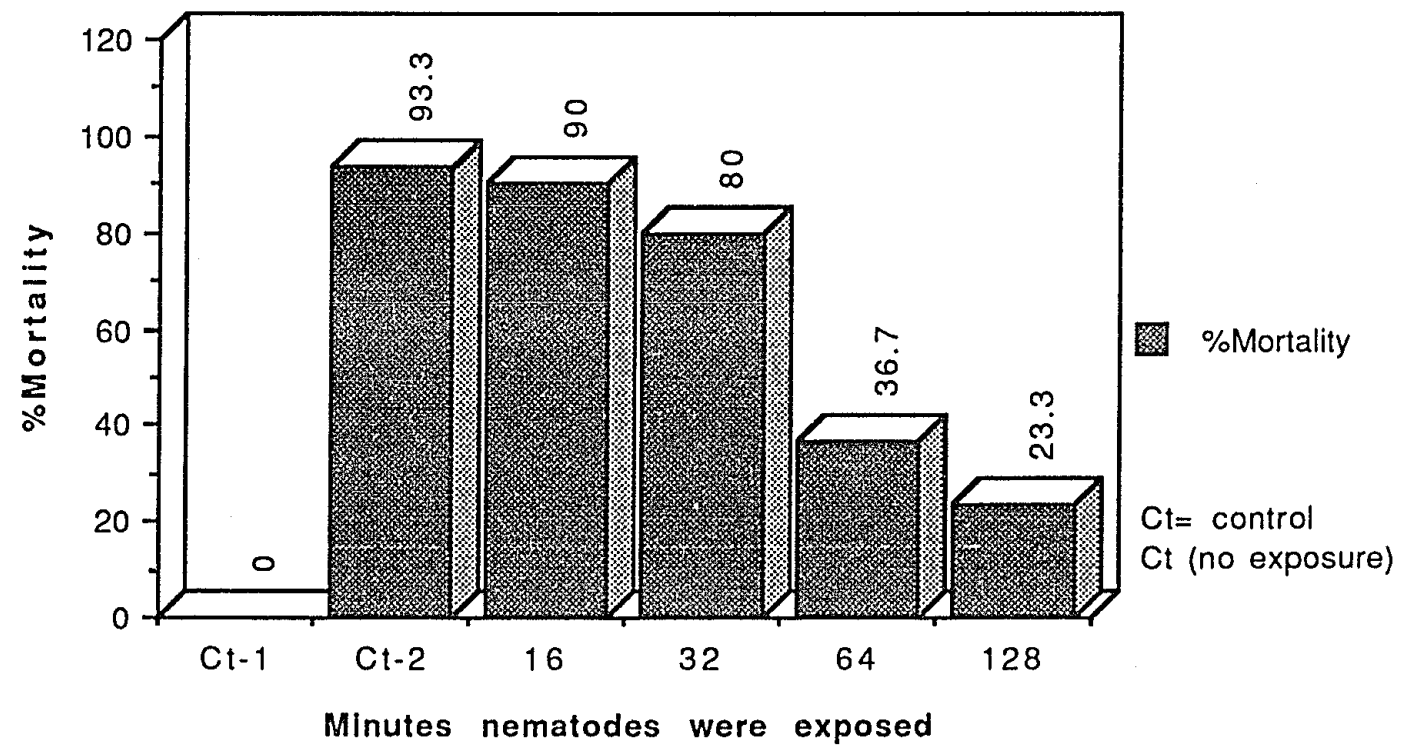


Fig.11 Percent mortality of black cutworm, 96 hours after treated with nematodes, when nematodes were kept indoors under the controlled conditions (first test).

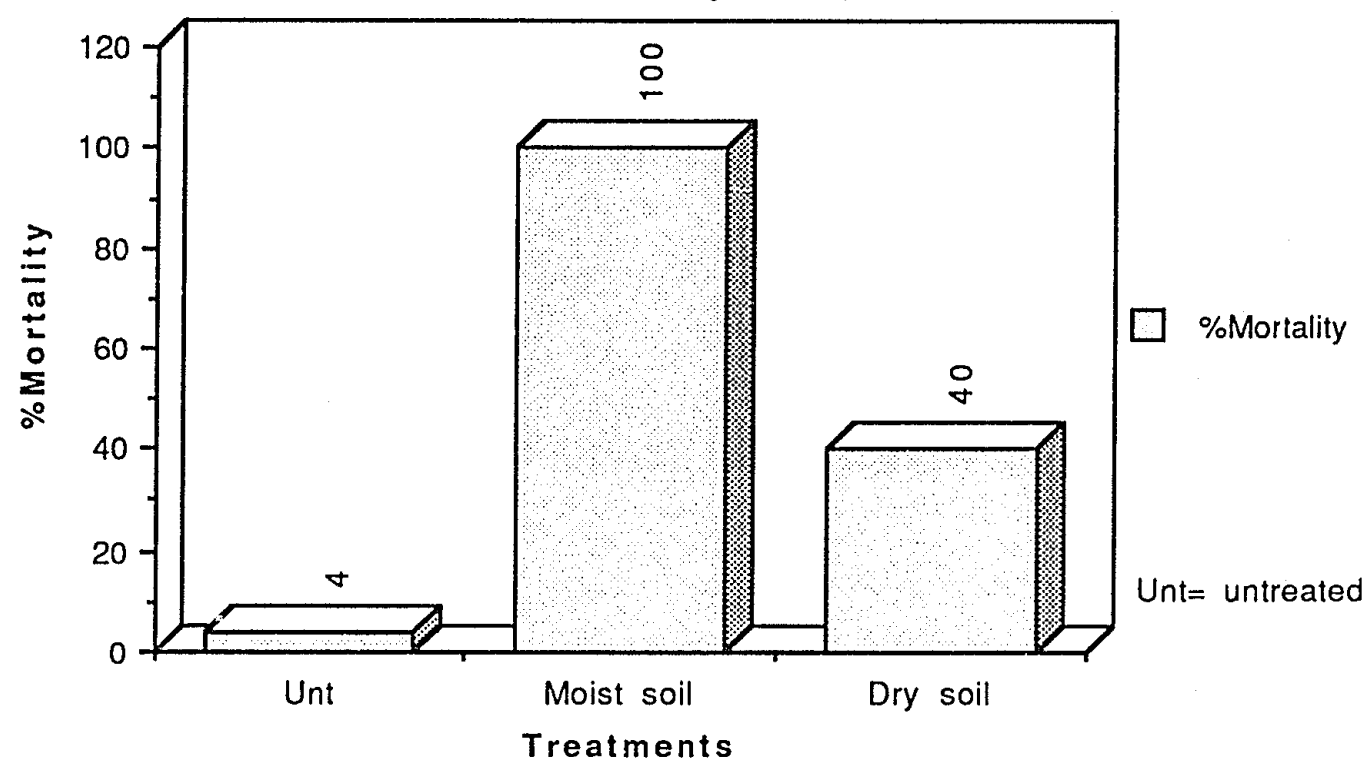

Fig.12 Percent mortality of black cutworm, 96 hours after treated with nematodes, when nematodes were kept indoors under the controlled conditions (confirmation test).

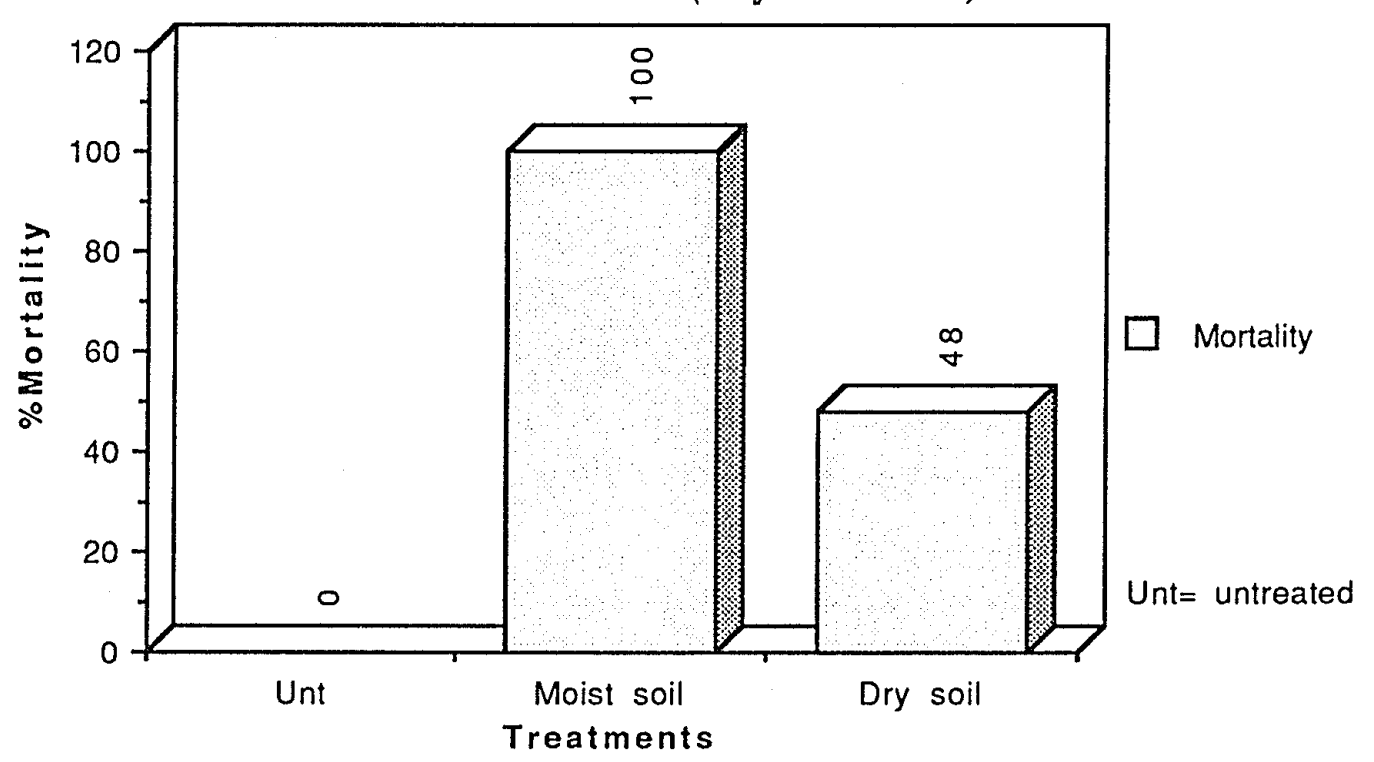


Fig.13 Percent cutworm damage to cabbage plants, 96 hours after treated with nematodes, when nematodes were kept indoors under the controlled conditions (first test).

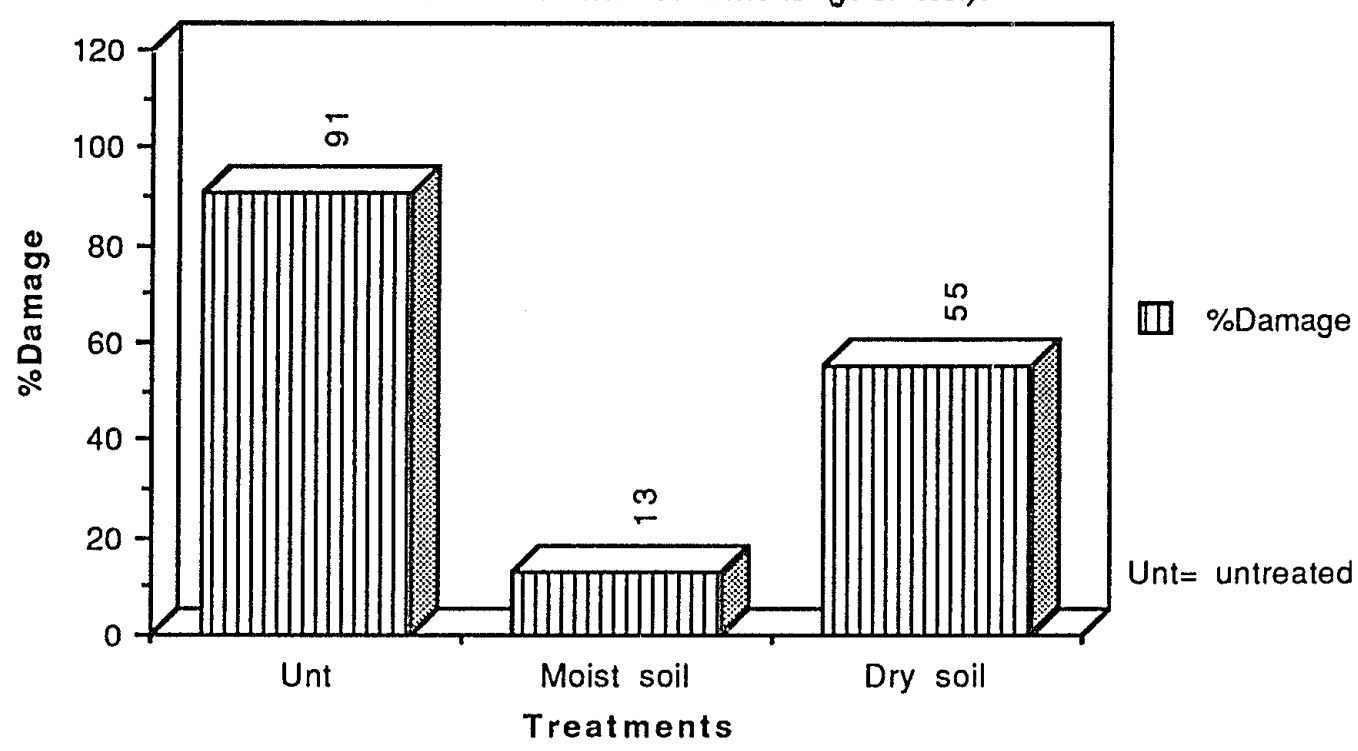

Fig.14 Percent cutworm damage to cabbage plants, 96 hours after treated with nematodes, when nematodes were kept indoors under the controlled conditions (confirmation test).

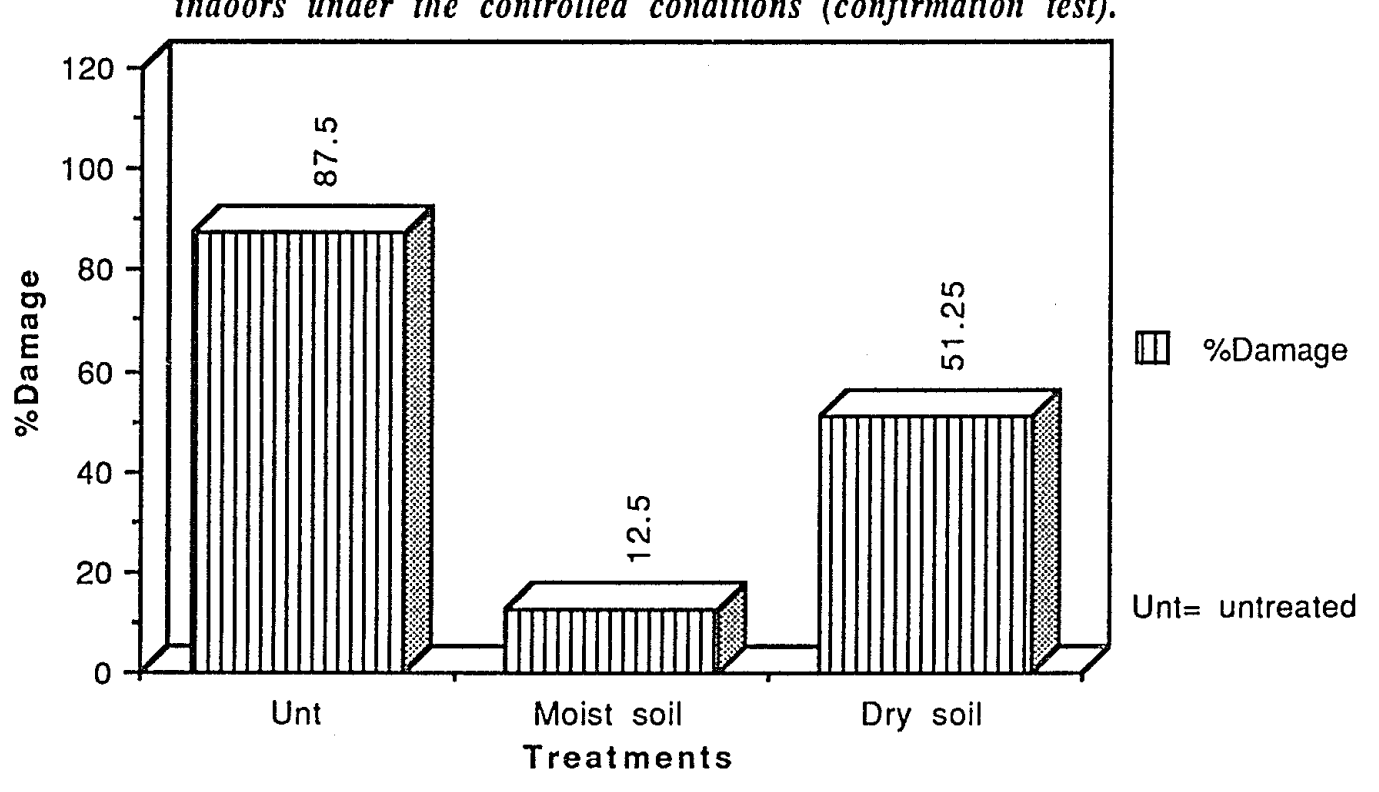


Fig.15 Percent mortaltiy of black cutworm, 96 hours after treated with nematodes (first test, morning applications).

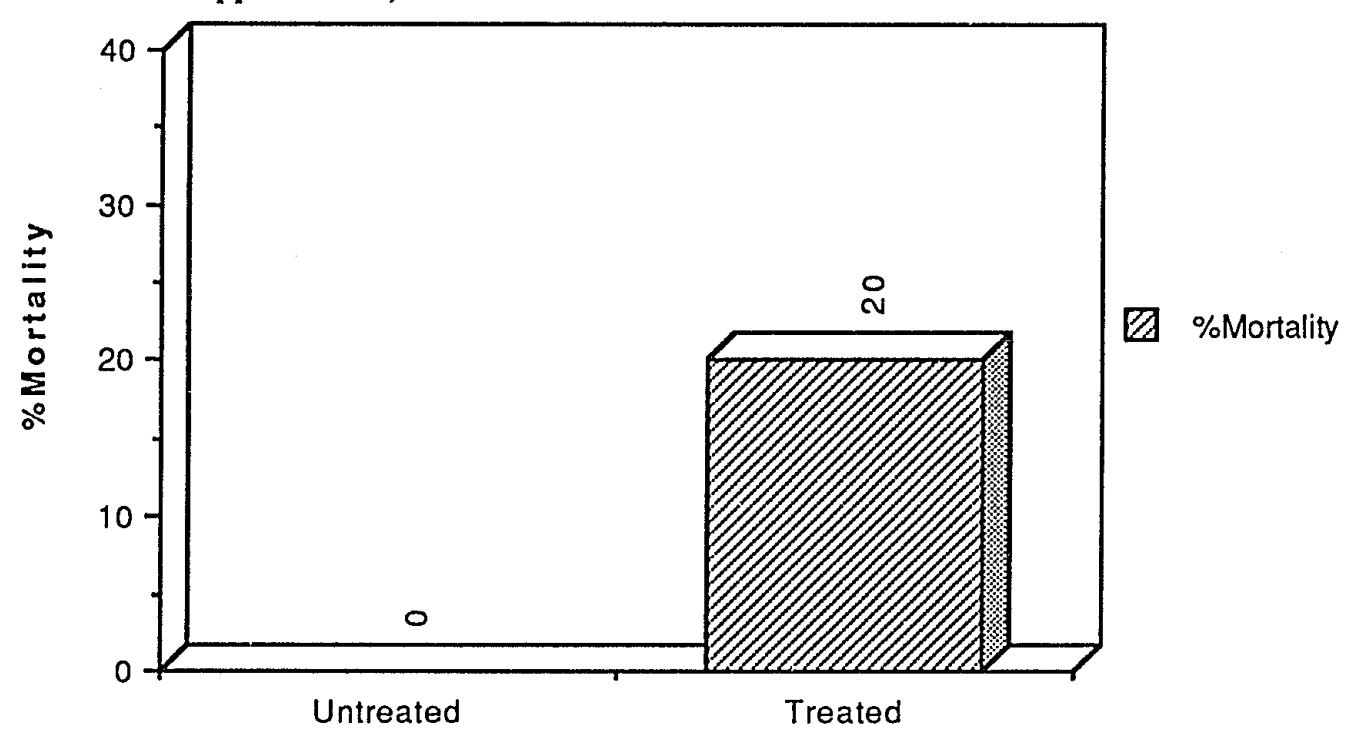

Fig.16 Percent mortality of black cutworm, 96 hours after treated with nematodes (confirmation test, morning applications).

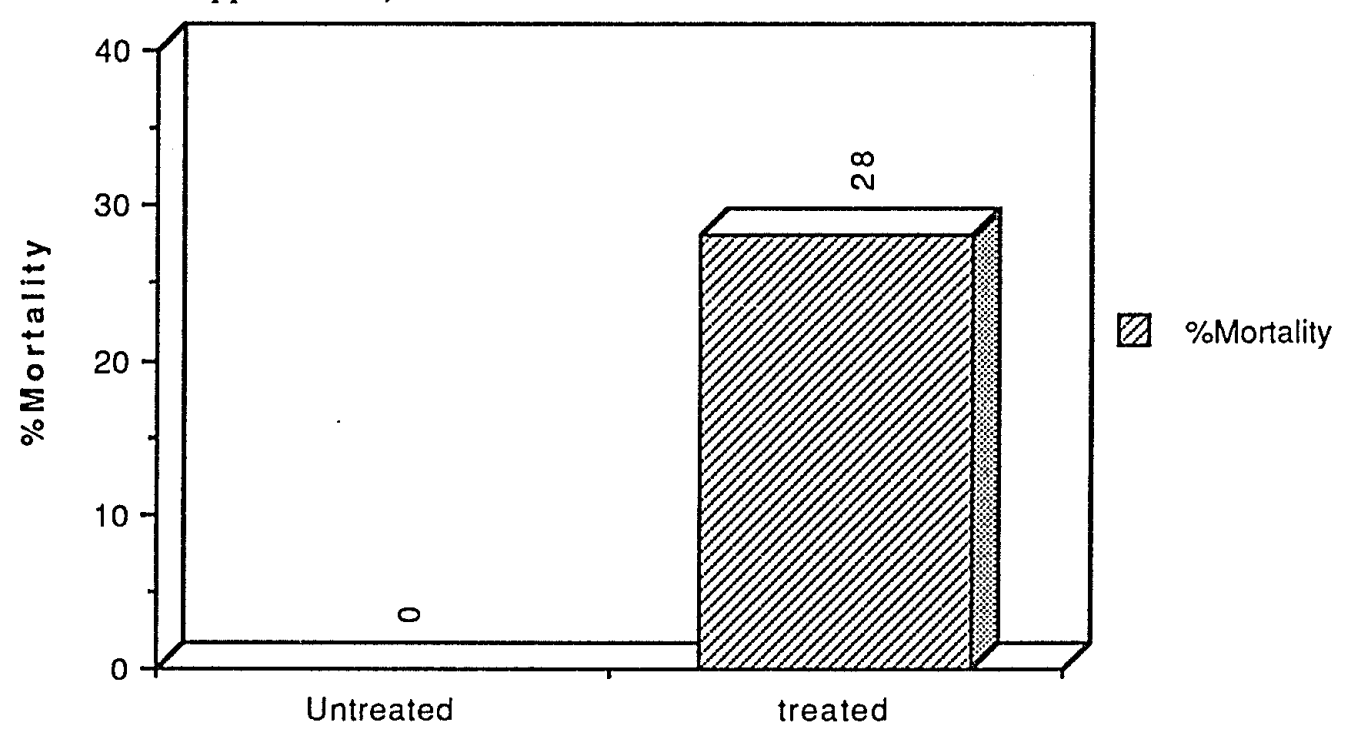


Fig.17 Percent cutworm damage to cabbage plants, 96 hours after treated with nematode (first test, morning applications).

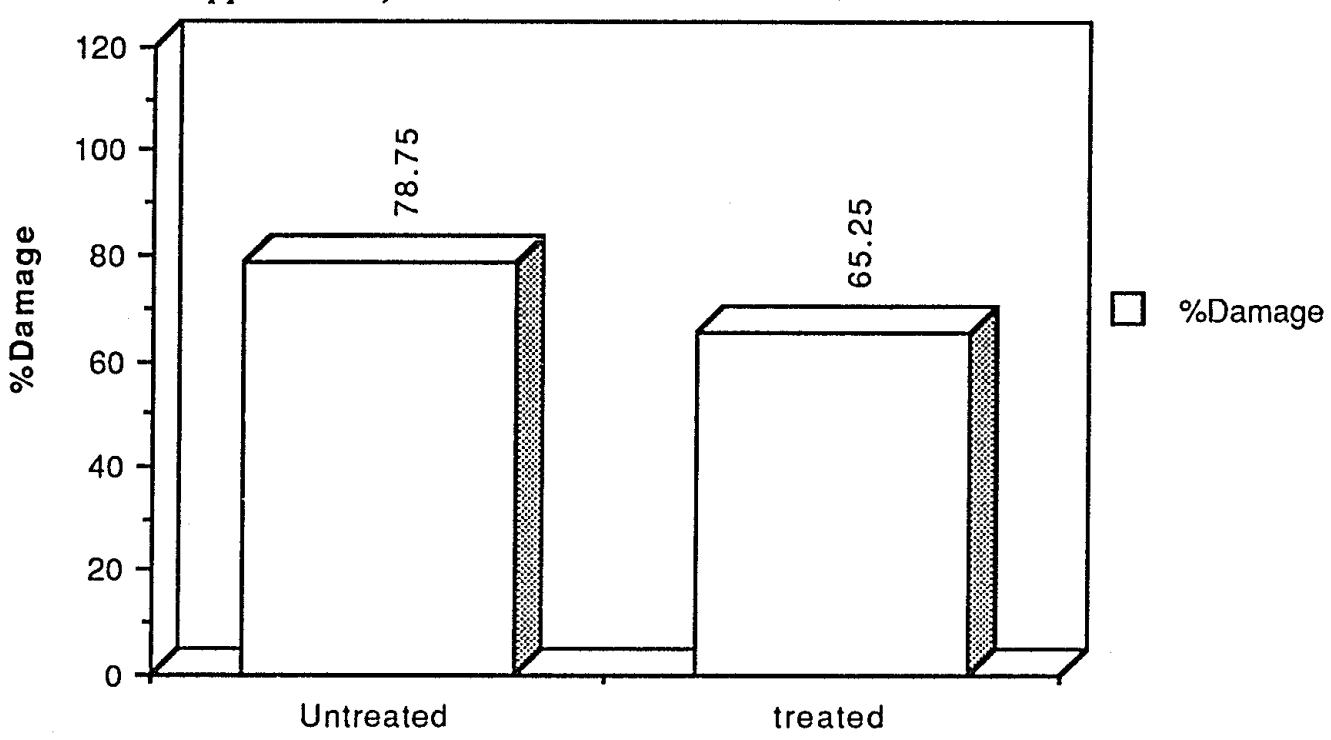

Fig.18 Percent cutworm damage to cabbage plants, 96 hours after treated with nematodes (confirmation test, morning applications).

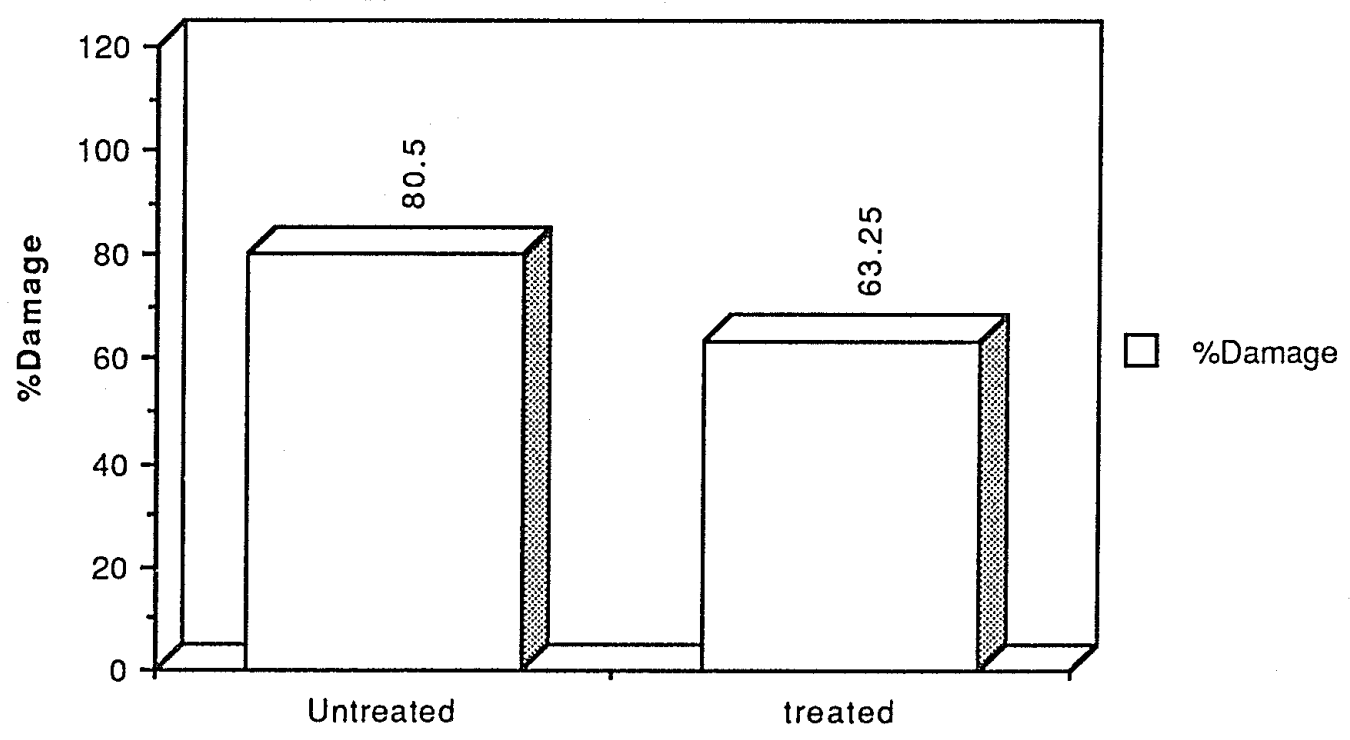


Fig.19 Percent mortality of black cutworm, 96 hours after treated with nematodes (first test, late afternoon applications).

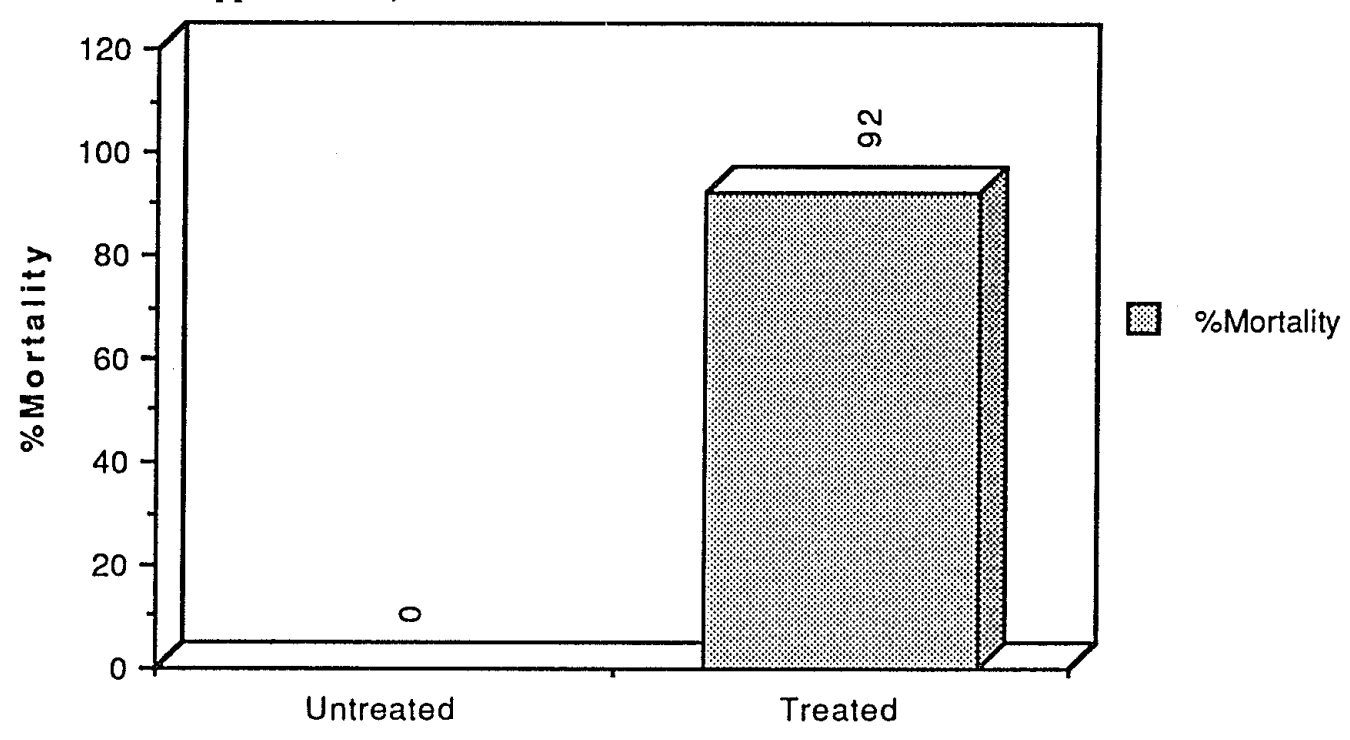

Fig.20 Percent mortality of black cutworm, 96 hours after treated with nematodes (confirmation test, late afternnon applications).

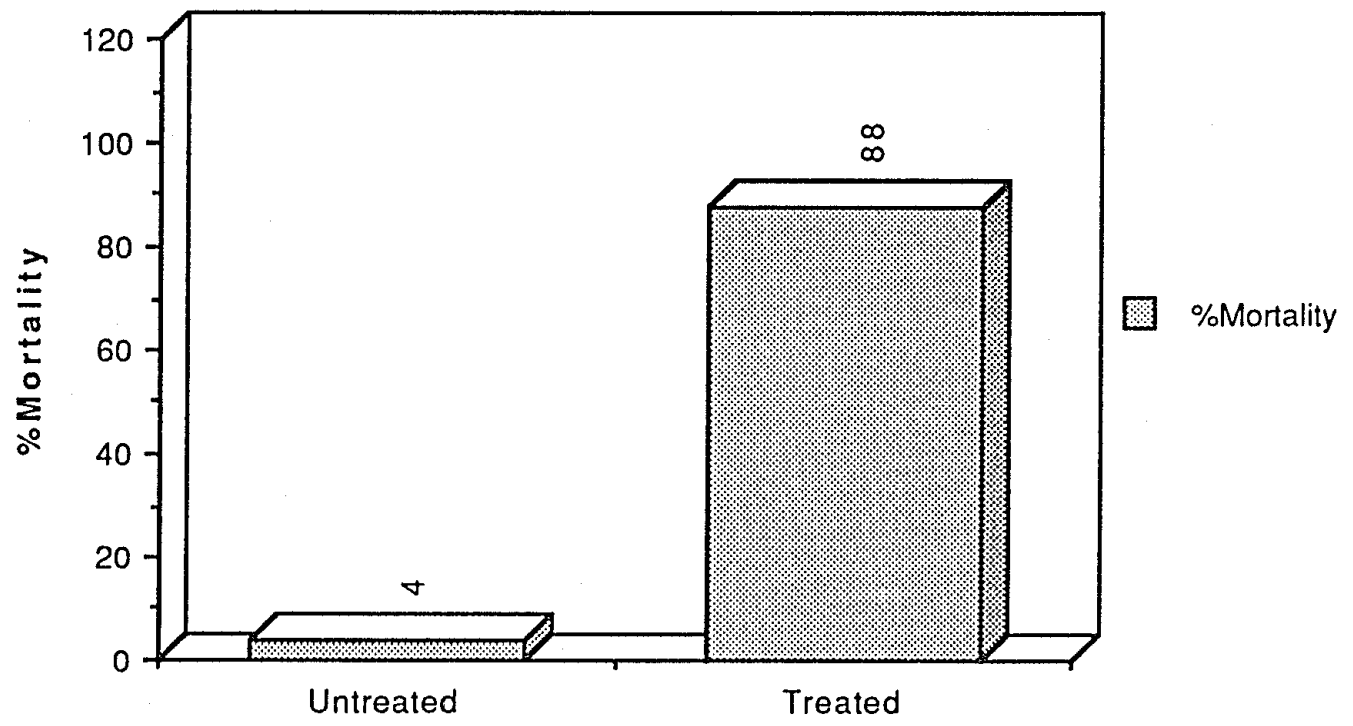


Fig.21 Percent cutworm damage to cabbage plants, 96 hours after treated with nematodes (first test, late afternnon applications).

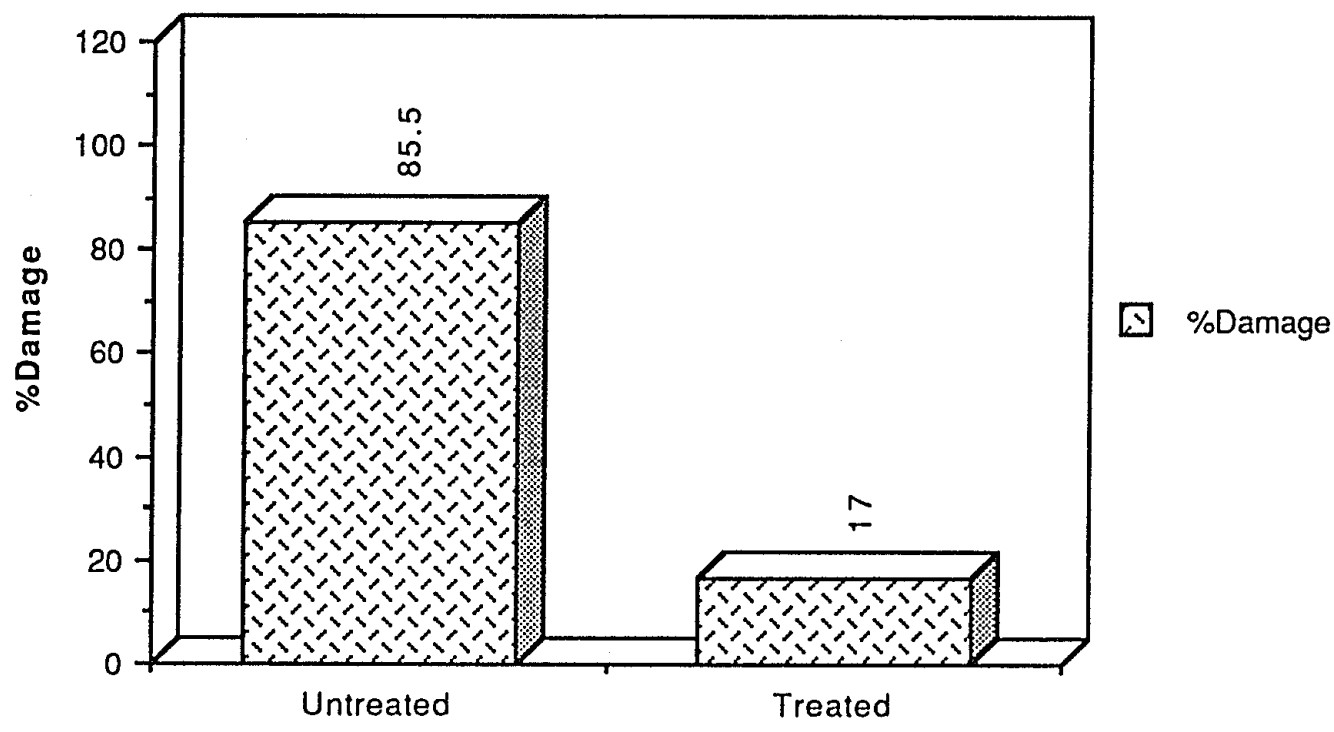

Fig.22 Percent cutworm damage to cabbage plants, 96 hours after treated with nematodes (confirmation test, late afternnon applications).

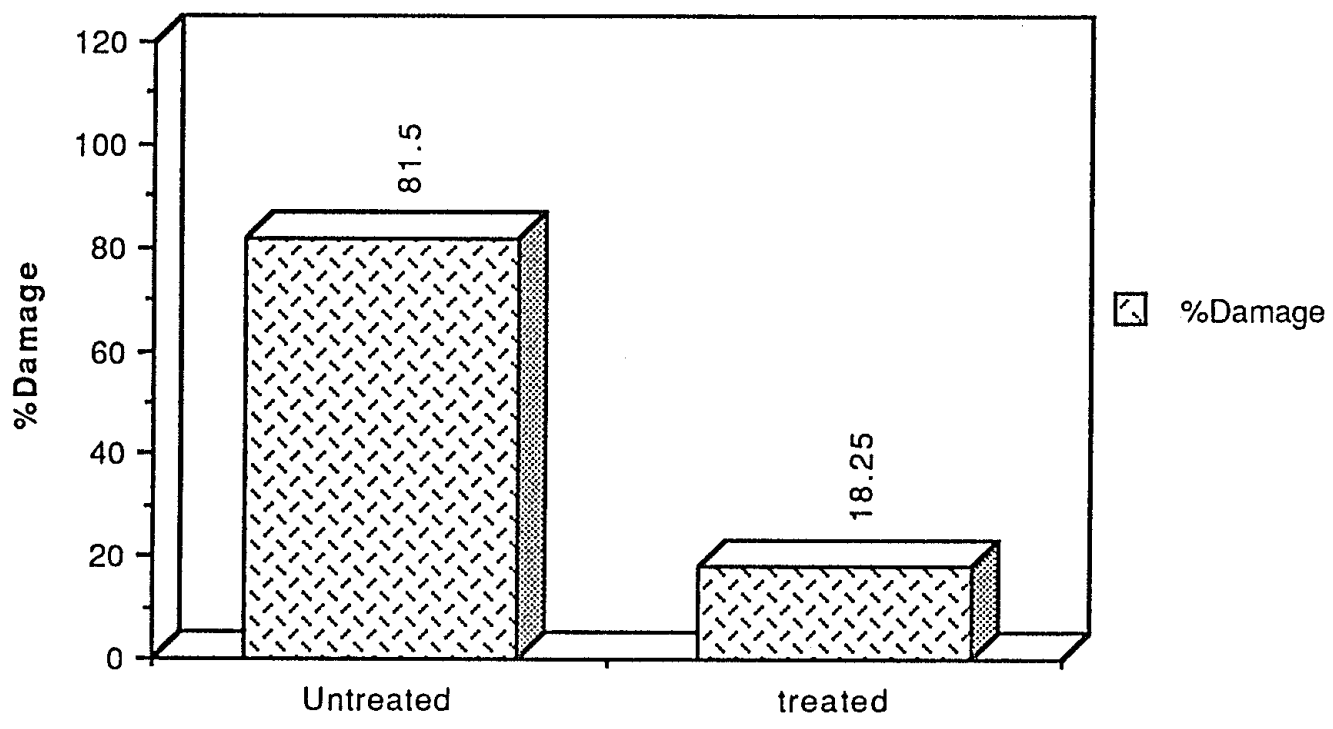




\section{BIBLIOGRAPHY}

Adkisson, P. L., E. S. Vanderzant, and D. L. Allison. 1960. A wheat germ medium for rearing the pink bollworm. Journal of Economic Entomology 53:759-762.

Akhurst, R. J. 1980. Morphological and functional dimorphism in Xenorhabdus spp. bacteria symbiotically associated with the insect pathogenic nematodes Neoaplectana and Heterorhabditis. Journal of General Microbiology 121:303-309.

Atkins, E. L. 1960. Cabbage looper on citrus. California Citrograph $45: 154-56$.

Bedding, R. A. 1984. Large scale production, storage and transport of the insect-parasitic nematodes Neoaplectana spp. and Heterorhabditis. Annals of Applied Biology 104:117-120.

Borror, J. Donald., and M. D. Delong. 1981. An introduction to the study of insects. Fifth Edition, Saunders College Publishing, Chicago p:543.

Bovien, P. 1937. Some types of association between nematodes and insects. Videnskabelige Meddelelser fra Dansk Naturhistorisk Forening p:55-57.

Brogdon, J. E., M. E. Marvel, and R. S. Mullin. 1970. Commercial vegetable insect and disease control guide. University of Florida, Extension Circulation, 193G, p:20.

Byers, J. A., and G. O. Poinar, Jr. 1982. Location of insect hosts by the nematode Neoaplectana carpocapsae in response to temperature. Behaviour 79:1-10.

Busching, M. K., and F. T. Turnip. 1976. Oviposition preferences of black cutworm moths among various crop plants, weeds, and plant debris. Journal of Economic Entomology 69:587-90.

Cobb, N. 1919. The orders and classes of nematodes. Contributions 
to Science of Nematology 8:213:216.

Cress, D., and A. Wells. 1976. "Cole crops insect pests," Michigan State University, Cooperative Extension Services, Bulletin E968, p:44.

Croll, N. A., and B. P. Matthews. 1977. The biology of nematodes. Halsted Press, New York p:44-46 and 152.

Crumb, S. E. 1929. Tobacco cutworms. United States Department of Agriculture, Technical Bulletin 88:1-175.

Dutky, S. R., J. V. Thompson, and G. E. Cantwell. 1964. A technique for the mass propagation of the DD-136 nematode. Journal of Insect Pathology 6:417-422.

Finney, D. J. 1964. Statistical method in biological assay. Second Edition, Griffin, London p:84-98.

Gaugler, R., and G. M. Boush. 1978. Effects of ultraviolet radiation and sunlight on the entomogenous nematode, Neoaplectana carpocapsae. Journal of Invertebrate Pathology 32:291-296.

Gaugler, R. 1979. Non susceptibility of rats to the entomogenous nematode, Neoaplectana carpocapsae. Environmental Entomology 8:658-660.

Gaugler, R., and G. M. Boush. 1979. Laboratory tests on ultraviolet protectants of an entomogenous nematode. Environmental Entomology 8:810-813.

Gaugler, R. 1981. Biological control potential of Neoaplectanid nematodes. Journal of Nematology 13:241-249.

Georgis, R. 1987. Nematodes for biological control of urban insects. American Chemical Society, Division of Environmental Chemistry, 194th National Meeting, New Orleans, Louisiana 27:(2)816-821.

Georgis, R., and R. Gaugler. 1991. Predictability in biological control 
using entomopathogenic nernatodes. Journal of Economic Entomology 84:(3)713-720.

Glaser, R. W., E. E. McCoy, and H. B. Girth. 1940. The Biology and economic importance of a nematode parasitic in insects. Journal of Parasitology p:479-495.

Gorsuch, A. M. 1982. Regulations for the enforcement of the federal insecticide, fungicide and rodenticide act exemption from regulation of certain biological control agents. Federal Register 47:23928-23930.

Gray, P. A., and D. T. Johnson. 1983. Survival of the nematode Neoaplectana carpocapsae in relation to soil temperature, moisture and time. Journal of Georgia Entomological Society $18(4): 452-454$.

Greene, G. L. 1972. Economic damage threshold and spray interval for cabbage looper control on cabbage. Journal of Economic Entomology 65:205-8.

Hall, I. M. 1957. Use of polyhedrosis virus to control the cabbage looper on lettuce in California. Journal of Economic Entomology $50: 551-553$.

Harris, C. R., J. H. Mazurek, and G. U. White. 1962. The life history of the black cutworm, Agrotis ipsilon, under controlled conditions. Canadian Entomologist 94:1183-1187.

Hill, D. S. 1983. Agricultural insect pests of the tropics and their control. Second Edition, Cambridge University Press, Cambridge p:98-101.

Ignoffo, C. M., and D. L. Hostetter, and D. B. Smith. 1976. Gustatory stimulant, sunlight protectant, evaporation retardant: three characteristics of a microbial insecticidal adjuvant. Journal of Economic Entomology 69(2):207-210.

Jaques, R. P. 1968. The inactivation of the nuclear polyhedrosis virus of Trichoplusia $n i$ by gamma and ultraviolet radiation. 
Canadian Journal of Microbiology 14:1161-1163.

Kaya, H. K. 1977. Development of the DD 136 strain of Neoaplectana carpocapsae at constant temperatures. Journal of Nematology 9:346-349.

Kaya, H. K., L. M. Marston., J. E. Lindegren, and Y. S. Peng. 1982. Low susceptibility of honey bee, Apis mellifera L. (Hymenoptera: Apidae) to the entomogenous nematode Neoaplectana carpocapsae Weiser. Environmental Entomology 11:920-924.

Kaya, H. K. 1985. Entomogenous nematodes for insect control in Integrated pest management systems. Academic Press, New York $\mathrm{p}: 283-294$.

Kaya, H. K., and R. Gaugler. 1990. Entomopathogenic nematodes in biological control. CRC Press, Inc., Boca Raton, Ann Arbor, Boston p:50-52 and 118 .

MacVean, C. M., J. W. Brewer, and J. L. Capinera. 1982. Field tests of antidesiccants to extend the infection period of an entomogenous nematode, Neoaplectana carpocapsae, against the colorado potato beetle. Journal of Economic Entomology 75:97-101.

McCollum, Ware. 1980. Producing vegetable crops. Third Edition, Interstate Printers and Publishers, New York p:257-270.

McEwen, F. L., and G. E. Hervey. 1960. Mass-rearing the cabbage looper, Trichoplusia ni, with notes on its biology in the laboratory. Annals of the Entomological Society of America $53: 229-234$.

McKinney, K. B. 1944. The cabbage looper as a pest of lettuce in the southwest. United States Department of Agriculture, Technical Bulletin 846:1-29.

Metcalf, R. L., and W. H. Luckmann. 1982. Introduction to insect pest management. Second Edition, Environmental Science and Technology, New York p:402. 
Meyer, B. 1989. Biosys' hypodermic needle of biocontrol-nematode alternative to chemical pest control. Agricultural Biotechnology News p:4-5 and 29.

Molyneux, A. S., and R. A. Bedding. 1984. Influence of soil texture and moisture on the infectivity of Steinernema glaseri for the larvae of the sheep blowfly, Lucilia cuprina. Nemtologica $30: 358-365$.

Moyle, P. L. 1980. Dispersal and infectivity of the entomogenous nematode, Neoaplectana carpocapsae (Rhabditida:

Steinernematidae), in sand. Masters Thesis, University of California, Davis p:15.

Moore, G. E. 1973. Moisture requirements of the DD-136 Strain of Neoaplectana carpocapsae (Nematoda; Rhabditida) as related to host infection. Experimental Parasitology 33:207-211.

Nickle, W. R. 1967. On the classification of the insect parasitic nematodes of the Sphaerulariidae Lubbock, (Tylenchoidea: Nematoda). Proceedings of the Helminthological Society of Washington 34:72-94.

Nickle, W. R. 1977. Taxonomy of nematodes that parasitise insects, and their use as biological control agents. Biosystmatics in Agriculture, Beltsville Symposium 2:37-51.

Nickel, W. R. 1984. Plant and insect nematodes. Marcel Dekker Inc., New York p:325-327.

Petersen, J. J. 1981. Status and future of entomogenous nematodes: symposium introduction. Journal of Nematology 13:239-240.

Poinar, G. O, Jr., and P. T. Himsworth. 1967. Neoaplectana parasitism of larvae of the greater wax moth, Galleria mellonella. Journal of Invertebrate Pathology 9:241-246.

Poinar, G. O. Jr., and R. Leutenegger. 1968. Anatomy of the infective and normal third-stage juveniles of Neoaplectana carpocapsae 
Weiser (Steinernematidae: Nematoda). Journal of Parasitology $54:(2) 340-350$.

Poinar, G. O, Jr. 1972. Nematodes as facultative parasites of insects. Annual Review of Entomology 17:103-122.

Poinar, G. O, Jr. 1976. Infection of adult lepidoptera by Neoaplectana carpocapsae (Nematoda). Journal of Invertebrate Pathology 27:413-414.

Poinar, G. O, Jr. 1979. Nematodes for biological control of insects. CRC Press, Inc., Boca Raton, Florida p: 88-91.

Poinar, G. O, Jr. 1983. The natural history of nematodes. Prentice Hall, Inc., Englewood Cliffs, New Jersy p:45 and 69.

Rings, R. W., F. J. Keaster., and A. J. Musick. 1974. A worldwide annotated of the black cutworm. Ohio Agricultural Research and Development Center, Research Circulation 198:33-34.

Rings, R. W., G. J. Keaster. and A. J. Luckman. 1976. Geographical distribution and economic importance of the black, glassy and bronzed cutworms. United States Department of Agriculture, Plant Pest Report 1(16):178.

Romoser, W. S., 1981. The Science of entomology. Second Edition, Macmillan Publishing Inc., New York p:437.

Satterthwait, A. F., 1933. Larval instars and feeding of the black cutworm, Agrotis ipsilon. Journal of Agricultural Research, Washington, D. C. 46:(6)56-59.

Schmidt, J., and J. N. All. 1978. Chemical attraction of Neoaplectana carpocapsae (Nematoda: Steinernematidae) to insect larvae. Environmental Entomology 7:605-607.

Schroeder, W. J., and J. B. Beavers. 1987. Movement of the entomogenous nematodes of the families Heterorhabditidae and Steinernematidae in soil. Journal of Nematology 19:(2)257259. 
Sechriest, R. E. 1967. Studies on black cutworm control. Proceedings North Central Branch Entomological Society of America 22:8993.

Shetlar, D. J., P. E. Suleman, and R. Georgis. 1988. Irrigation and use of entomogenous nematodes, Neoaplectana spp. and Heterorhabditis heliothidis (Rhabditida: Steinernematidae and Heterorhabditidae), for control of Japanese beetle (Coleoptera: Scarabaeidae) grubs in turf grass. Journal of Economic Entomology 81:1318-1322.

Shorey, H. H., L. A. Andres, and R. L. Haie. 1962. The biology of Trichoplusia ni (Lepidoptera: Noctuidae). I. Life history and behavior. Annals of Entomological Society of America 35:591598.

Simons, W. R., and G. O. Poinar, Jr. 1973. The ability of Neoaplectana carpocapsae (Steinernematidae: Nematoda) to survive extended periods of desiccation. Journal of Invertebrate Pathology 22:228-230.

Singh, P., and R. F. Moore. 1985. Handbook of insect rearing. Elsevier Science Publishers, New York 2:177-187, and 487495.

Sokal, R. R., and F. J. Rohlf. 1981. Biometry, the principles and practice of statistics in biological research. Freeman and Company, New York p:229-233.

Talbert, Jesse. 1953. Growing fruit and vegetable crops. Lea and Febiger, Philadelphia p:259-260.

Thomas, G. M., and G. O. Poinar, Jr. 1979. Xenorhabdus gen. nov., a genus of entomopathogenic, nematophilic bacteria of the family Enterobacteriaceae. International Journal of Systematic Bacteriology 29:352-360.

Thompson, H. C., and W. C. Kelly. 1957. Vegetable crops. Fifth Edition, Mcgraw-Hill Book company, New York p:275-277. 
Towson, A. J. 1983. Effect of soil water potential on survival of Meloidogyne javanica in fallow soil. Journal of Nematology 15:(1)110-115.

Webster, J. M. 1972. Nematodes and biological control. Academic Press, New York p:469-495.

Webster, J. M. 1980. Biocontrol, the potential of entomophilic nematodes in insect management. Journal of Nematology 12:270-276.

Welch, H. E. 1963. Entomophilic nematodes. Research Institute, Research Branch, Canada Department of Agriculture, Belleville, Ontario p:275-294.

Wiley, J. 1991. Crop protection chemicals reference. Chemical and Pharmaceutical Publishing Corp, New York p:31 and 81.

Wilson, M. C., F. T. Turpin, and A.V. Provonsha. 1977. Practical insect pest management, insects of livestock and agronomic crops. Waveland Press, Inc., Illinois p:115-117.

Wilson, M. C., A. C. York, and A. V. Provonsha. 1977. Practical insect pest management, insects of vegetables and fruit. Waveland press, Inc., Illinois p:76-79.

Wouts, W. M. 1980. Biology, life cycle and redescription of Neoaplectana bibionis Bovien. Journal of Nematology 12:6272. 